\title{
On the Relations between Host and Parasite in the Bromes and their Brown Rust, Puccinia dispersa (Erikss.)
}

\author{
BY \\ H. MARSHALL WARD, D.Sc., F.R.S., \\ Fellow of Sidney Sussex, Honorary Fellow of Christ's College, and Professor \\ of Botany in the University of Cambridge.
}

\section{INTRODUCTORY.}

OME years ago I gave a summary of the factors and $\checkmark$ questions involved in the study of the relations between host and parasite in certain epidemic diseases of plants ${ }^{1}$, and have at various opportunities since then continued investigations into that subject. In particular, I have for some time been occupied with researches planned with the object of ascertaining more concerning the modes of infection and attack of the Uredo-form of certain Rust-fungi.

During the course of this work I had occasion to select a particular genus of grasses, viz. the Bromes-with the view of examining their anatomy and histology in detail, in reference to the behaviour of the fungus in their tissues. In course of time a series of phenomena came to light which led me to go further into the conditions of infection, and to make numerous experiments with the Uredo of the Brown RustPuccinia dispersa-so common on certain species of this genus. These experiments led to some unexpected results, and the purpose of the present paper is to put together these

1 Croonian Lecture, Proc. R. S., vol. 47, I890, p. 393.

[Annals of Botany, Vol. XVI. No. LXII. June, 1902.] 
results, since they appear not only of considerable interest and importance by themselves, but promise to throw additional light on some vexed questions of parasitism and immunity, and on the relations between the host-plant and its invading or attacking fungus.

I shall here confine myself entirely to the genus Bromus and the Uredo of the Brown Rust-Puccinia dispersa-leaving any questions concerning the Teleutospores and Aecidia for further investigation, except in so far as it may be necessary to make reference to them in the form of notes in the sequel.

The plan of the work, as thus extended, concerns the characters and behaviour of the 'seed' and the seedlings of the species of Bromus examined, together with observations on the leaves of young plants, and the systematic relationships of these species: the description of methods of culture by which these grasses can be grown and kept growing absolutely free from danger of accidental infection by rust fungi: the means by which pure cultures of the Uredo in question can be transferred to such pure cultures of the Bromes, and the comparison of infected and noninfected plants compared; and, lastly, the behaviour of the Uredo itself on, and in, the different species.

The facts and experiments soon raised a number of questions in their turn, among which those of specialized parasitism, the persistence of the Uredo-form and the delimitation of species, and Eriksson's 'mycoplasm' theory are important.

In my work on Hemileia in $188 \mathrm{I}-2$, the uredine which caused the coffee-leaf disease in Ceylon, I was much impressed by the probability, amounting almost to a certainty, that the species Hemileia vastatrix on Coffea had originated by the special adaptation of a certain species, Hemileia Canthii, wild in the native forests on Canthium, to the cultivated coffee. When once this fungus had learned, so to speak, to attack the coffee-plant, it proved a disastrous parasite capable of becoming epidemic on its new host. Complete experimental proof of this was not obtained, but 
I was able to show that the Hemileia on Coffea Arabica will infect C. Liberica.

Since then Eriksson has elaborated a theory of adapted parasitism in connexion with the rusts of our cereal grasses, which has assumed a degree of importance so grave, and so full of consequence for the understanding of the epidemic diseases of cereals, that any investigations throwing further light on the matter are welcome. Eriksson found, in fact, that the so-called rust of wheat (Puccinia graminis) is a collective species, the morphological characters of which are now very thoroughly known, which behaves differently according to the particular host to which it has adapted itself as a parasite ${ }^{1}$. For instance, if we take the uredospores growing on wheat and sow them on rye, barley, or oats, the results are negative. Nevertheless $P$. graminis occurs on these plants, and forms uredospores on them. If, similarly, the uredospores from rye be sown on oats, the results are negative, whereas if sown on barley they infect it.

In other words Puccinia graminis, while it infects all the above-mentioned plants, and preserves its morphological characters on all of them, is so closely adapted to the particular host it happens to be on at the time, that the uredospores from this host can only attack successfully and directly either this particular host or a limited number of its immediate allies. And the same specialized parasitism occurs in the case of other species of rusts, growing on different hosts.

It thus becomes evident that we must modify our ideas considerably as to the danger of infection of wheat by the uredospores of $P$.graminis growing in its neighbourhood on some other grass. Further research showed, for instance, that the uredospores of this fungus on the weed-grass Agropyrum repens will infect rye but not wheat, and similarly with that on Elymus arenarius. On the other hand, the uredospores-of the same Puccinia-growing on Dactylis will attack oats but not rye, and similarly in other cases. The

1 See Eriksson in Bot. Gaz., I898, vol. xxv, p. 26, for summary and literature. 
next question which arises is: How does this fungus pass successfully through its summer form-the Uredo-stage-if its power of direct infection is thus limited? We know of course, since De Bary's classical proof, that it passes the winter in the teleutospore-stage to infect barberries in the spring by means of the sporidia borne on its pro-mycelium, and so forth. But, as Barclay showed, there are districts where the barberry is either wanting or very rare, and nevertheless the Uredo-form is never wanting on the cereals. To some extent the explanation is afforded by the repeated and continual infection and re-infection of grasses which follow on one after the other as regards the growing season. But Eriksson's researches led him to conclude that there is evidence of there being limits to this, and although the Uredo may thus persist on the weed-grasses, it by no means follows that it does so to such an extent as theory has demanded.

Another idea which arose out of these results was that the different specialized forms-which, though not morphologically distinct are physiologically different one from anotherare incipient species; that the particular specialized race adapted to growth on wheat, but not on rye or barley, is in course of becoming a species, and may during the lapse of time actually become a species of Puccinia, which will eventually show morphological differences in addition to the physiological ones it already shows. Various names have been proposed for these physiologically, but as yet not morphologically, different varieties of Puccinia graminis. Eriksson termed them 'special forms' (formae speciales ${ }^{1}$ ), Rostrup names them 'Biological species' (biologische Arten), Schroeter chose the term Species sorores, and Magnus calls them 'adapted races' (Gewohnheitsrassen'). Not much of importance is perhaps to be derived from the terminology, but it is pretty clear that each authority recognizes more or less clearly some aspect of one and the same underlying idea, viz. that each of these specialized forms has received from its host an impress, not perceptible in any visible difference

1 Eriksson, 1. c., p. 92. 
of shape, size, colour or other. morphological characters, but differing in some capacity of reaction towards another host. It is, of course, a matter of pure hypothesis as to whether these intangible physiological differences will ever bring about morphological changes of so obvious and relatively permanent a nature that we should then recognize the differences as specific. As will be seen, also, there is danger of some confusion of ideas as regards adaptation and variation on the part of the fungus, and we must not lose sight of possible reactions of the nature of resistance or predisposition on the part of the host.

So impressed was Eriksson with the significance of his share of the foregoing facts, and especially with certain difficulties met with in explaining the sudden and serious epidemic outbreaks of rust which occasionally occur, that he committed himself in 1897 to the remarkable hypothesis that at certain seasons the rust-fungus attacks the grass, e.g. wheat, and passes the protoplasm of its spores into the embryo, or some other part of the plant, where it mingles with the protoplasm of the host, and lives a common life of symbiosis with the living cell-contents, to break out suddenly at a favourable opportunity as rust. This supposed symbiotic form merged in the protoplasm of the host he termed Mycoplasm. This is not the place to enlarge upon the fact, which all who have followed his splendid investigations into wheat-rust must admit, that anything on this question coming from Eriksson is entitled to respectful consideration; but it does appear pertinent here to say that the question may be raised, whether Eriksson had not done better to retain the first term which gave the title ${ }^{1}$ to his communication on this subject ; for while there is plenty of evidence that the mycelium can remain dormant at certain times and under certain conditions in leaves unsuitable for its further development, there is little or none so far as I can find to support his hypothesis of this mysterious Mycoplasm.

1 Vie latente et plasmatique de certaines Urédinées. Compt. Rend., 1897, p. 475 . 


\section{The Rusts OF THE BROMES.}

In their book on the Rusts of the Cereals, published in I $896^{1}$, Eriksson and Henning gave detailed descriptions of six species of Puccinia. Of these four also occur on various species of Bromus.

These are (I) P.graminis, Pers., or Black Rust, found on Bromus asper, B. brizaeformis, B. erectus, B. giganteus, $B$. Gussonii, B. lanuginosus, B. longiflorus, B. maximus, $B$. tectorum, $B$. Wolgensis-all recorded for Sweden-and on $B$. mollis and $B$. pitensis according to other authorities.

The Aecidium-form of this species is the classical Aecidium berberidis so well known since De Bary's discovery of heteroecism.

(2) P.glumarum, Schm., or Yellow Rust, found on Bromus adoënsis, $B$. asper, B. arvensis, B. mollis, B. secalinus, B. sterilis, and $B$. tectorum by various authorities who have referred it to $P$. rubigo-vera. D. C. ( $P$. striaeformis, Westd., and $P$. straminis, Fuck.) No Aecidium-form of this has yet been discovered.

(3) $P$. dispersa, Erikss. and Henn., or Brown Rust, is found on $B$. arduennensis, $B$. arvensis, $B$. patulus, $B$. squarrosus, and, judging from herbarium specimens, on $B$. mollis, $B$. sterilis, and $B$. tectorum.

The Aecidium-form of this species is said to occur on Anchusa.

(4) P. coronata, Corda, or Crown Rust, occurs on B. asper, $B$. inermis, and $B$. mollis according to various authorities.

The Aecidium-form of this species is found on species of Rhamnus.

With the other two species of Eriksson and Henning's book we are not concerned, since they do not occur on Bromes. It may suffice to note that one of them, viz. P. Phlei-pratensis, Erikss. and Henn., the Timothy Rust, is a species separated off from the old $P$. graminis, Pers., as peculiar to the grass

1 Die Getreideroste. Stockholm, 1896. 
whence its name is derived, while the other, $P$. simplex, Kcke., has been separated off from the old $P$. rubigo-vera, D. C., as peculiar to Hordeum.

In 1897 , in fact, the three hitherto accepted species of grainrusts had been broken up as follows :-

(I) $P$. graminis, Pers., into $P$. graminis and $P$. Phleipratensis.

(2) P. rubigo-vera, D. C., into P. glumarum, Er. and Henn., $P$. dispersa, Er. and Henn., and the variety $P$. simplex, Kcke.

(3) $P$. coronata, Corda, into $P$. coronifera, Kleb, $P$. coronata, $\mathrm{Kleb}$, and an eighth form on Calamagrostis and Melica as yet unnamed.

Moreover, each of these species possessed several formspecies, or specialized races, morphologically indistinguishable but physiologically confined to certain hosts ${ }^{1}$.

Since I am here concerned only with the Uredo-forms of the species given, the following comparison must be supplemented by reference to the authorities quoted for information as to the teleutospores, \&c.

I may, however, add the morphological definitions of the species, so far as the Uredo-forms are concerned.

Puccinia graminis, Pers. The Black Rust of cereals.

The Uredo pustules occur as large elongated spots, $2-3 \mathrm{~mm}$. in length and sometimes confluent, especially on the sheaths, and may then be very long, up to $10 \mathrm{~mm}$. or more. They are yellow-brown-brown-ochre, or sienna-in colour, and bear uredospores which are of a dirty yellow hue, and echinulate, and measure about $17-40 \times 14-22 \mu$.

Puccinia glumarum, Er. and Henn. The Yellow Rust of wheat.

The Uredo pustules, or sori, are O.I-I $\mathrm{mm}$. long and $0.3-0.4 \mathrm{~mm}$. broad. In linear series confluent in long streaks at the leaf-apex, and may be there grouped into diseaseflecks as much as $70 \mathrm{~mm}$. long. They are apt to be more

\footnotetext{
1 See Eriksson, Ber. d. D. Bot. Ges., I897, Bd. xv, p. I83, and Bot. Gaz., I898,
} vol. $\mathrm{xxv}, \mathrm{p} .28$, for details. 
scattered on the inside of the glumes and paleae. The colour is citron-yellow or pale-cadmium. The spores are globoid, or shortly ellipsoid, echinulate and yellow, measuring $25-30 \mu$ in diameter.

Puccinia dispersa, Er. The Brown Rust of cereals.

The spots or sori of uredospores are I-I.5 mm. long by hardly I $\mathrm{mm}$. broad, and are scattered without definite order over the whole leaf-surface, instead of forming defined confluent soral flecks. The colour is brown, i. e. brown-ochre or sienna. The uredospores are globoid or shortly ellipsoid, and echinulate. Yellow and from $19-29 \mu$ diameter.

Puccinia coronata, Corda. The Crown Rust of cereals.

The uredo-spots or sori are sometimes long, up to $9 \mathrm{~mm}$. or so, and somewhat confluent, but they may be only $0.3-$ $0.2 \mathrm{~mm}$. diameter. On the lamina they occur mostly above, rarely on the sheath, haulms, glumes, or paleae, and are redyellow in colour. The uredospores are globoid or shortly ellipsoid, and echinulate, of a bright yellow hue, and measure $20-32 \mu$ diameter or $28-32 \times 20-24 \mu$.

In 1900 , Eriksson ${ }^{1}$ passed on to a further subdivision of the Brown Rust of the cereals (Puccinia dispersa). Having found that the forms on Secale, on Triticum, on Bromus, and on Agropyrum are mutually exclusive as to their host-genera, he proposes to regard each as a species, under the names Puccinia dispersa (on Secale), P. triticina, P. bromina, and $P$. agropyrina. To these he adds $P$. holcina and $P$. Triseti. We are here concerned only with the form named by him $P$. bromina, the Uredo of which may be described as follows ${ }^{2}$ : sori $\mathrm{I}-\mathrm{I} O \mathrm{~mm}$. long $\times \mathrm{I} \mathrm{mm}$. broad, ferruginous, throughout the lamina, at first above, aggregated. At length occupying the sheath and even the inflorescence. Spores globoseellipsoid, echinulate, 20.8-24 $\mu$ diameter. Easily germinating.

1 Nouvelles études sur la rouille brune des céréales. Ann. des Sc. Nat., $7^{\ominus}$ sér., T. ix, p. 24I. Eriksson here accepts thirteen species in all.

${ }_{2}$ The aecidium form has since been discovered, according to Müller, Beitr. z. Bot. Cent., Bd. x, I90I, p. 182, and is found on Pulmonaria and Symphytum, not on Anchusa. 
I have found the fungus thus described on the following plants: $-B$. mollis, common and very strongly developed both in the open fields and in the garden; $B$. sterilis, equally common, though the pustules on the wild plants in the hedgerows and fields were never so strongly developed or so large as on the wild $B$. mollis. In the gardens, on wellgrown plants, they were sometimes equally good however. On $B$. secalimus, in the garden only, where the pustules were finer than any others. B. brizaeformis, only in the Botanic Garden, and strongly developed. On B. arvensis, B. macro. stachys, $B$. brevirostratus, $B$. longiflorus, and $B$. purpureus, all growing in the gardens in tufts close to those already mentioned, the pustules were fewer and, as a rule, less welldeveloped.

I have failed to observe this fungus on $B$. inermis, $B$. echinaceus, $B$. madritensis, or $B$. maximus, even on tufts growing close to and intermingled with those mentioned.

On a species marked $B$. asper, in the gardens, but which turned out to be $B$. arvensis when critically examined in flower, a second Uredo was equally common with that of the Brown Rust, Puccinia dispersa, viz. P. glumarum, the Yellow Rust, a point of some importance in connexion with certain experiments.

This confusion of names also brings prominently forward the necessity of having perfectly accurately named 'seed' of the varieties and species to be experimented with, and I had to go into this question very carefully in preparation for what follows.

\section{ON the Species of Bromus used in THE EXPERIMENTS.}

Hackel, following to some extent Bentham and Hooker ${ }^{1}$, divides the genus Bromus into five subgenera as follows :-

(I) Festucoides. Perennial, mostly tall and with loose panicles. The first glume I-nerved, the second 3-nerved.

1 See Genera Plantarum, vol. iii, p. I200, and Hackel, Die natïrl. Pflanzenfamilien, I I. Th., 2. Abt., p. 75. See also Ascherson, Syn. d. mittel-europ. Fl., I90I, p. 574, for a critical review and differences in detail. 
Outer palea shortly awned, the upper very finely ciliate on the ridges :-e. g. B. evectus, Huds., B. inermis, Leyss., B. asper, Murr., B. ciliatus, L.

(2) Stenobromus. Low annuals, with narrow spikelets broadening upwards. Glumes as in (I). Lower palea keeled, long-awned; the upper stiffly ciliated. Weeds, e.g. B. tectorum, L., B. sterilis, L., B. madritensis, L., B. maximus, Desf., $B$. giganteus, L.

(3) Zeobroma (Serrafalcus). Annuals with ovoid or lanceolate spikelets narrowing upwards. Outer glume 3-5-, inner 5-7-nerved. Lower palea 7-9-nerved, and keelless; awn often spreading, rarely obsolete. Upper palea stiffly ciliate, e.g. B. brizaeformis, Fisch. and Mey., B. macrostachys, Desf., B. secalimus, L., B. arvensis, L., B. mollis, L., B. racemosus, L.

(4) Libertia. As Zeobromus, but the outer palea with two lateral projections. $B$. arduennensis, Kunth.

(5) Ceratochloa. Spikelets lanceolate, compressed. Glumes and paleae many nerved, keeled; ovary evidently 3-humped, e. g. B. unioloides, Kunth.

Of these I have made a more or less thorough examination of the following representatives. In the following notes on the 'seeds' and seedlings the British forms are marked with an asterisk. It should be borne in mind that these notes are only intended to indicate the plants I have been using; materials are being accumulated for a more comprehensive treatment of the whole genus on which I am engaged ${ }^{1}$.

\section{(I) Festucoides.}

*B. erectus, Huds. B. inermis, Leyss.

*B. asper, Murr. B. ciliatus, L.

$B$. erectus, Huds.

A native of Europe and Asia Minor and N. Africa, is essentially a dry meadow species, and is scattered but not uncommon throughout the chalk districts of Cambridge. It

1 I am glad to take this opportunity of thanking Mr. Lynch, the Curator of the Botanic Garden, for the trouble he has taken in germinating and growing in pots for me many species of Bromes. 
is regarded as a valuable fodder-grass in some regions, and Chatin ${ }^{1}$ mentions it as having been one of the best of all grasses in withstanding the hot dry summer of 1892 .

$B$. erectus is allied to $B$. asper, as is evident in the form and constitution of the spikelets, but its contracted stiffer panicle, narrower leaves, and differences in sheaths, habitat, \&c., distinguish it. It is, however, an extremely variable species, and numerous races and varieties are described ${ }^{2}$.

The 'seed' ${ }^{3}$ of $B$. erectus is narrow and long, about 10-14 $\times I \mathrm{~mm}$. or, with the awn, I4-20 mm. Rachilla oblique above, 2-4 $\mathrm{mm}$. long, and beset with rough short hairs. Lower palea papery at edges, nearly flat, fimbriated above; the upper palea almost fully exposed, very thin. Caryopsis navicular, dark-brown, with a broad shallow ventral groove. Hilum a narrow black line. There is a faint dorsal keel. Apex tufted with remains of style. Colour in the mass grey, the darker caryopsis shining through the pale-yellowish paleae.

The 'seed' germinated very badly, and only very few plants were as a rule obtained. In a second consignment, in fact, none germinated in a sample of thirty-four sown (No. 745).

$$
\text { B. asper, Murr. }
$$

Is a species of Europe, except the extreme north, and the Orient extending into India and N. Asia, and has been introduced into $\mathrm{N}$. America. All authorities agree that it comes near $B$. erectus, and we may therefore put it here. In the London Catalogue it is indexed as B. ramosus, Huds., with two varieties. The dispute as to the name and varieties is dealt with by Trimen and others ${ }^{4}$, and need not concern us here; but I can lay no stress on the characters of ramification of the panicle, and it seems difficult to keep the varieties apart.

1 Compt. Rend., cxv, 1892, p. 397.

2 See Ascherson, Syn. d. mittel-europ. H1., I 901, p. 577.

3 'Seed' here signifies the true fruit (caryopsis) enclosed in its paleae.

- Trimen, Journal of Botany, viii, I870, p. 376. See also Ascherson, Syn. d. mittel-europ. Fl., p. 575 . 
The 'seed' of $B$. asper resembles that of $B$. erectus in general shape and size, but is heavier and more plump. It is somewhat cylindroid, measuring about $10 \times 1.5 \mathrm{~mm}$., and with short awn ( $4-5 \mathrm{~mm}$.), palea finely nerved and upper end ciliate. Rachilla somewhat long.

The four-day seedlings of $B$. asper showed very slow germination, the radicle having only just appeared, the plumule not yet evident from between the pale thin yellow paleae. Awn short and fine. Outer palea flatter and thinner than in the $B$. sterilis type, and approaching the 'boat type' 1 of the Serrafalcus group.

\section{B. inermis, Leyss.}

Occurs in Europe, the Caucasus, and N. Asia. It is regarded as an important grass for very dry climates, its perennial creeping rhizomes enabling it to withstand the aridity of the Steppes and dry prairies. B. inermis is closely allied to the widely spread North American B. ciliatus, L., which may be regarded as its New World representative; but although $B$. inermis is not a native of America, it grows well there-e.g. on the Pacific Coast-and has been widely introduced elsewhere, as the Hungarian or Awnless Brome.

The 'seed' of $B$. inermis is much flattened; and awnless or with a mere trace of awn. Size $10-12 \times 2 \mathrm{~mm}$. Lower palea flat, distinctly nerved above, margins curved in slightly below. Apex somewhat torn. Upper palea closely adherent to caryopsis. Rachilla short, about $2.5 \mathrm{~mm}$., stiffly hairy, hardly projecting. Caryopsis $6-10 \mathrm{~mm}$. long, very flat, slightly sinuous, acute at both ends, hairy above. Median ventral furrow very shallow; hilum a mere ridge or keel owing to the adherent palea. 'Seed' in the mass yellowishgrey.

The 'seed' germinates fairly well, but slowly. Of $4 \mathrm{I}$ 'seeds' sown, only I3 germinated in five days, and on the sixth day the seedling was somewhat characteristic owing to the bluntly rounded, somewhat torn palea.

\footnotetext{
1 See Marshall Ward, 'Grasses,' pp. I27-I 28.
} 


$$
\text { B. ciliatus, L. }
$$

Is a N. American species occurring all over from Newfoundland to New York, westward to Minnesota, Iowa, and northwards into Canada, and south to Texas. It is placed by Britton and Brown next $B$. erectus and $B$. asper, and grows in woods and thickets. It has wider leaves, stouter culms, and more diffuse and drooping branches to the panicle than $B$. erectus, and the sheaths are devoid of the long retrorse hairs so characteristic of $B$. asper. Several varieties have been described ${ }^{1}$, of which $B$. purgans (B. pubescens, Muhl.) is well marked by its more pubescent paleae hairy all over, and B. laeviglumis, Scribner, which has nearly glabrous paleae with at most a very slight pubescence on the margins near the base. The latter occurs in Maine to N. Carolina and extends into Canada.

I have not as yet had the opportunity of growing and experimenting with the true $B$. ciliatus, $L$. Under the name $B$. ciliaris, Torr., I have received what is a totally different plant, as the seeds and seedlings show.

$B$. canadensis is somewhat like $B$. asper in general appearance, but rather flatter, $13-14 \times 2 \mathrm{~mm}$. and with fimbriated membranous palea above; awn $8 \mathrm{~mm}$. Nerves indistinct, glabrous. Colour yellow-grey.

$B$. canadensis, Michx., is the same as B. ciliatus, L., according to the 'Index Kewensis,' cf. Michx. Flor. Bor. Ann. i. 65 and Linn. Sp. Plant. 76.

B. canadensis was found to germinate very poorly. In five days only two, and on the sixth day only five had moved out of a batch of nineteen sown.

\section{(2) Stenobromus.}

B. tectorum, L. *B. sterilis, L.

*B. madritensis, L. B. maximus, Desf.

$1 B$. ciliatus (Huds.) is the very different B. madritensis (L.); and B. ciliatus (Muhl.) is B. Kahlmii (A. Gray). B. ciliatus (Lam.) is Brachypodium distachycum (Beauv.). 


\section{B. sterilis, L.}

Is common in Europe, the Orient, and North Asia. It is an abundant and well-known weed, and one of the earliest of our grasses, extremely common in Cambridge, and one of our most characteristic hedge species. It is now extensively naturalized in Ohio and other parts of America, in Jamaica, in Australia, and elsewhere in our Colonies.

$B$. sterilis 'seed' is so like that of $B$. maximus that one can only distinguish them by the size. 'Seed' I $5 \times$ I. $5 \mathrm{~mm}$. exclusive of paleal teeth $(3-4)$ and awn $(24 \mathrm{~mm}$.) The purple colour is perhaps more pronounced however, and the steelyblue colour which diffuses out on germination seems characteristic, since no such stain comes from $B$. maximus, though it does from $B$. tectorum and, to a less extent, $B$. madritensis.

Seedlings four days old show a spear 8-10 $\mathrm{mm}$. long, and a beautiful steel-blue colour diffuses around into the filter paper.

In a week pot-plants were $5-10 \mathrm{~mm}$. high. The first sheath pink, and the spear very narrow. In five days the spears in the intermediate pit were $5^{-10} \mathrm{~mm}$. up.

Seedlings in the open with 3-4 leaves had the lamina $8-8.5 \mathrm{~cm} . \times 3.5 \mathrm{~mm}$. There is a distinct keel, running down on to the sheath, and about six light lines on either side of the midrib. Ridges above, low and rounded, and about three show on each side of the sheath-keel. Spreading hairs, especially on the upper surface, keel and edges of the blade, but mostly on the keel of the sheath. The sheath is split at its apex, but complete elsewhere. The right edge rolls over the right, and the broad leaves are soon reflexed, and tend to twist.

\section{B. tectorum, L.}

Is native in Europe, North Africa, the Orient, and North Asia. It is, like B. sterilis, a weed of poor soil, \&c. I found it abundant at Stalden, and in some other parts of the Saas Valley. It occurs occasionally in England, but only as an introduced alien. The 'seed' sent me as B. ciliaris, Torr., 
is very similar (see below, p. 256). The spikelets do not readily break up, the cylindroid narrow 'seeds' are grey with a purple or rosy cast, 9.5-10 $\times 1 \mathrm{~mm}$, with an awn longer than itself, I $5 \mathrm{~mm}$., springing from between two teeth of the papery palea. These teeth are colourless and $\mathrm{t} \cdot 5^{-2} \mathrm{~mm}$. long, transparent. Nerves about five and fairly clear.

$B$. tectorum germinated readily, sixteen out of twenty-five 'seeds' sown having germinated on the fourth day (No. 745). The seedling was scarcely distinguishable from that of $B$. sterilis, and the same steel-blue stain diffused out during the first two days.

\section{B. madritensis, L.}

Is a species of Europe, North Africa, and the Orient. It occurs in Jersey, and has become established here and there on the Channel coasts of England and Ireland. B. diandrus, Curt., is a form with two stamens, a condition not confined to this Brome. $B$. madritensis is almost indistinguishable from $B$. sterilis. It is about $I 6 \times 2 \mathrm{~mm}$. Awn $25 \mathrm{~mm}$. Teeth and long rachilla similar. All authorities put it near $B$. sterilis.

The four-day seedlings, as well as those in pots a week old, were quite like those of $B$. sterilis, but slower in growth, the sheaths of the spears, 5-10 $\mathrm{mm}$. high, being green without any bronze. In five days in the intermediate pit, the spears were $5 \mathrm{~mm}$. high, but two of them had leaves opening and $2 \mathrm{~cm}$. long.

\section{B. maximus, Desf.}

Is a native of the Mediterranean and Caucasus, occurring also in Jersey, and comes close to B. sterilis and B. tectorum, but is larger. Boissier puts it near $B$. madritensis ${ }^{1}$. It is reported also from South Africa.

$B$. maximus. The 'seed' is long and narrow, the much-

1 According to the Index Kewensis, B. maximus (Desf.) is the same as B. rigidus (Roth.) Cf. Desf. Flor. Atl., i, 95, t. 26, and Roth in Roem. and Ust. Mag. Bot., iv (1790), 2 I. Ascherson, Syn. d. mittel europ. Fl., p. 594, adopts the name $B$. villosus, Forsk. 


\section{Ward.-On Relations between Host and Parasite}

inrolled palea terminating in two long slender papery teeth from between which the long slender awn arises. From base of 'seed' to apex of teeth $23-25 \mathrm{~mm}$., the teeth themselves 5-6 mm. Awn about $40 \mathrm{~mm}$. Breadth of 'seed' about $2 \mathrm{~m}$. Colour dark-grey-mouse colour-with a purple cast. Rachilla long. The whole 'seed' and awn covered with minute forward asperities. Seedlings when four days old a spear about $2 \mathrm{~mm}$. long, and much like the smaller and more quickly growing $B$. sterilis.

In a week the pot-seedlings had a leaf projecting $2 \mathrm{~cm}$. above the ground, the apex unfolding and the whole of a beautiful bronze-green. It showed five veins, and had stiff short hairs on the back, and was $2 \mathrm{~mm}$. broad. The direction of rolling seemed to vary, but was usually such that the right edge comes over the left.

In five days, forced plants in the intermediate pit had strong spears $5^{-10} \mathrm{~mm}$. high.

(3) Zeobromus, Serrafalcus.

$* B$. secalinus, *B. velutinus, *B. mollis, *B. intermptus, $* B$. racemosus, $B$. commutatus, $B$. arvensis, B. brizaeformis, B. macrostachys.

On comparing the 'seeds' of $B$. mollis, L., B. interruptus, Hack., B. arvensis, L., B. racemosus, L., B. commutatus, Schrad., B. secalinus, L., B. velutinus, it is clear that we have a series of very closely allied forms, bearing out Bentham's contention that they should all be put as varieties or subspecies of one- $B$. arvensis. It is now usually conceded that $B$. arvensis, $\mathrm{L}$., is not native in this country, and that $B$. secalinus with its variety $B$. velutinus, $B$. mollis with its variety $B$. interruptus, and $B$. racemosus with its variety $B$. commutatus, may be claimed as species ${ }^{1}$. In any case they are undoubtedly closely allied, and form the typical nucleus of the group or sub-genus Serrafalcus, formerly indeed separated as a genus from Bromus.

On comparing a series of the germinated seedlings of these

1 See Ascherson, Syn. d. mittel-europ. Fl., for a critical survey of these relationships. 
species, all sown at the same time on moist filter-paper in glass dishes, and kept side by side, also very little difference can be seen between them except in minute points, as is evident on comparing the ripe 'seed' and the seedlings on the fourth day.

Seedlings in pots, also treated exactly alike, gave the following points, which, as before, I append to notes on the species as here understood.

\section{$B$. arvensis, $\mathrm{L}$.}

Is common in Europe, the Orient, and North Asia, and has spread to the Cape and elsewhere. It often gives the impression of being a diminutive or starved form on arid lands, and frequently occurs on sea-coasts. It is, however, not often found wild in this country and is probably not nativethe view taken by the London Catalogue, 9th ed., I 895, p. 44. There is room for suspicion that $B$. arvensis is sometimes confused with other species. The 'seed' of $B$. arvensis is the smallest of all I have experimented with, except perhaps the one called $B$. pratensis, and averages $7 \mathrm{~mm}$. by I $\mathrm{mm}$., the awn being about as long, viz. $7 \mathrm{~mm}$. The papery margin of the palea is much infolded and the nerves not very distinct. In the mass the 'seed' is grey-yellow with touches of purple.

$B$. arvensis, a week old, had a leaf $\mathrm{I} \cdot 5 \mathrm{~cm}$. long by about I $\mathrm{mm}$. broad, bronzed, and rolled, with stiff spreading hairs. Forced in the intermediate pit, the spears averaged $\mathrm{I} c \mathrm{~cm}$. high. Seedlings a fortnight old showed a single blade $6.5 \mathrm{~cm}$. long by I mm., with two ridges each side the midrib, and ciliated as were also the margins. Sheath almost devoid of hairs. 'Seed' small.

It is smaller than B. vacemosus but similarly flat, with thin membranous edges to the outer palea. The plumule is also perhaps a trifle longer and pinkish above. The whole outline narrower and the awn longer.

In seedlings grown in the open ground and having three or four green leaves, the lamina of the first developed leaf 
averaged 4-5 $\mathrm{cm}$. long by I $\mathrm{mm}$. broad. It had a few spreading hairs, but showed very few positive characters. The sheath was completely closed to near the apex, the ligule short and slightly fringed, and the lamina showed about three whitish lines on each side of the midrib. The first developed leaf is hardly acute : the succeeding taper to a long point and measure $10-12 \mathrm{~cm}$. by $2 \mathrm{~mm}$. The keel is hardly noticeable. These seedlings were the narrowest of all as regards leaves.

\section{B. mollis, L. ${ }^{1}$}

The 'seed' of $B$. mollis comes next in size, being $9 \times 1 \cdot 5^{-}$ $2 \mathrm{~mm}$. and the awn $8-9 \mathrm{~mm}$. The five nerves on the palea are quite clear at the top, where the palea is also flattened, giving the greater width and tendency to a 'coracle-shape' to the whole. In the mass the seed is pale greyish-yellow.

The palea of the germinating seed (four days old) was broader and more flattened than in the preceding three forms. In seedlings a week old the one leaf stands up $2 \mathrm{~cm}$. and is $1.25 \mathrm{~mm}$. broad, with three veins and a few hairs especially on the upper surface. The sheath bronzed and veined, but soon becoming bright green. In the intermediate pit the spears were $\mathrm{I} \mathrm{cm}$. high in five days. In three-leafed seedlings the first leaf is $6-7 \mathrm{~cm}$. by $\mathrm{I} .25 \mathrm{~mm}$. and acute, the third about $9 \mathrm{~cm}$. by $2 \mathrm{~mm}$. with three pale lines and four ridges each side the midrib. Keel hardly observable. Habit somewhat stiff. Hairiness not pronounced. Sheaths slightly tinged with red.

On the whole it is most like B. racemosus, but even more expanded and more distinctly nerved in the outer palea: plumule green.

B. mollis comes from Europe, Africa, and North Asia, and is one of our commonest road-side and farm-weeds. It is not confined to dry places, however, and I find it common in the wet meadows near Lingay Fen, and elsewhere in Cambridge. There are at least three ordinary varieties, according

${ }^{1} B$. hordeaceus, L. See Ascherson, Syn. d. mittel-europ. Fl. 
to the London Catalogue. Like so many other Bromes, and perhaps more than most, it has been extensively introduced as a weed of cultivation into the Colonies and elsewhere abroad: e. g., Canada, Australia, the United States, India, \&c.

\section{B. intermptus, Hack.}

Approaches $B$. mollis and $B$. vacemosus in many characters, measuring $9 \times 2 \mathrm{~mm}$. and awn 9-10 $\mathrm{mm}$. It is slightly downy. In the mass the colour, \&c., are the same. It differs in the marked tendency of the florets to remain in the spikelet. Its chief characteristic, however, is the split inner palea, which is cut to the base in the median line.

$B$. interruptus seemed sharply distinct by the non-separation of the 'seeds' in the spikelet, and consequently germinates in tufts of about 5-7. It was not up in a week, but quickly rose about the eighth or ninth day. In other respects it resembles $B$. arvensis, $B$. mollis, and $B$. racemosus. In the intermediate pit the spears were $I \mathrm{~cm}$. high in five days. The third leaf is $10-12 \mathrm{~cm}$. by $2 \mathrm{~mm}$. and resembles the species named.

The four-day seedlings are also exactly like parallel cultures of $B$. mollis, except that the spikelets do not so readily break up, and the germination is slower. The plumule is green and not bronzed.

$B$. interruptus, Hack., is regarded by the editors of the London Catalogue, $9^{\text {th }}$ ed., I 895 , as a variety of $B$. mollis, L., a view supported by my examination of the seedlings. It was discovered by Druce in $1895^{1}$ in England, and is sharply marked by the deeply split inner palea.

\section{B. racemosus, $\mathrm{L}$.}

Has a larger 'seed' than B. mollis-e.g., Io $\times 2-2.5 \mathrm{~mm}$. with awn 9-Io $\mathrm{mm}$.- though otherwise they are similar in shape (the palea lying open) and colour. Perhaps the ciliation and nervation are less evident in B.racemosus. In the mass

${ }^{1}$ See Journ. Bot., 1895 , p. 344 , and 1897 , p. 18. Also Journ. Linn. Soc., I 896, vol. xxxii, p. 426 . 


\section{Ward.-On Relations between Host and Parasite}

it is difficult to detect any difference beyond size. The fourday seedlings are like those of the last species. In a week the first leaf-spear is I-2 $\mathrm{mm}$. above ground, and in a pot five days in the intermediate pit only two spears showed, about $5 \mathrm{~mm}$. high. B. racemosus, L., is a common European plant, and regarded by Bentham as merely a smoother variety of $B$. arvensis. But we must bear in mind the extensive definition of the latter species given by Bentham. The more usual view is to regard it as a good species ${ }^{1}$.

\section{B. commutatus.}

Is quite like $B$. racemosus, of which it is often regarded as a variety. The 'seed' measures $10 \times 2 \mathrm{~mm}$. with an awn the same length. The colour may be a trifle paler in the mass, but there are no marked points of difference to be seized.

The seedlings of $B$. commutatus are also very like those of $B$. racemosus. In a week the spears were $2-3 \mathrm{~mm}$. high, and in the intermediate pit the tips only just showed in five days.

In a fortnight the total height was about $8 \mathrm{~cm}$. The leaf averaged $6 \mathrm{~cm} . \times 2 \mathrm{~mm}$. and had seven ribs; the cilia, hairs, ridges, \&c., were like $B$. arvensis, and the sheath almost smooth.

$B$. commutatus resembles also $B$. mollis in four-day seedlings, but is far behind it in rapidity of germination.

$B$. commutatus, Schrad., is synonymous with $B$. racemosus according to the Index Kervensis, cf. Fl. Germ., i. 353. In the London Catalogue, gth ed., 1895, p. 44, it is accorded specific rank $^{2}$, however, with two varieties.

\section{B. secalimus, L.}

Next in point and size comes $B$. secalinus, which is rounded and fatter and more bulky and corn-shaped than any of the foregoing. Length $7 \mathrm{~mm}$., breadth $2 \mathrm{~mm}$., and thickness about the same. Awn 5-6 mm. In the mass the 'seed' is distinctly heavier : in colour it is grey-yellow like $B$. mollis.

\footnotetext{
${ }^{1}$ Lond. Cat., ninth ed., 1895, p. 44.

${ }^{2}$ See also Ascherson, 1. c., p. 6ra.
} 
$B$. secalinus. On the fourth day no differences were observable beyond the shorter spear and the characters of the paleae.

In a week the spear was less than a centimetre high, the membranous sheath being smooth and brown-pink. Slightly forced in the intermediate pit, the spears were not above ground on the fifth day. Three-leafed seedlings are more robust and taller than those of $B$. arvensis, the third leaf being $12-15 \mathrm{~cm}$. long by $2.5-3 \mathrm{~mm}$. wide, with $3-4$ pale lines each side the midrib. The first leaf-about $6 \mathrm{~cm}$. by $2.3 \mathrm{~mm}$. -is soon reflexed, as is also the case in B. arvensis. Beyond the broader leaves and more robust habit-very noticeable in pots of several-however, it was not easy to distinguish them.

The four-day seedlings of $B$. secalinus bring out well the character of plumpness of the 'seed' as compared with $B$. racemosus. The spear is also stout and pink-sheathed, not green as in that form. The awn is also shorter and the nervature of the inner palea less evident: this palea is ciliate, the outer one slightly hairy. B. secalinus, L., is a native of Europe, the Mediterranean, and N. Asia. It is regarded by Bentham as a tall cornfield variety of $B$. arvensis, but we must remember that he gives a very wide definition to the latter ${ }^{1}$. It has spread widely to the United States, Canada, and elsewhere.

$B$. velutimus seems indistinguishable from $B$. secalimus in size, shape, and colour. It is a trifle more hairy, however, though that is only seen on close examination. In the mass the colour and weight are similar. $B$. velutinus is very like $B$. secalinus in four-day seedlings. The seed is fat, a trifle hairy and ciliate, and the short plumule slightly pink above.

$B$. velutinus was indistinguishable from $B$. secalinus by any positive characters. The awn of the 'seed' appeared a trifle longer, and the length of the third leaves somewhat shorter, but in all essential respects they appear to be the same species.

$B$. velutinus, Schrad., is given as a synonym of $B$. secalinus

1 See Ascherson, 1. c., p. 602。 


\section{Ward.-On Relations between Host and Parasite}

in Index Kewensis, cf. Flor. Germ., i. 349, t. 6, f. 3. It is generally regarded as a distinct variety of that species-see Lond. Cat., 1895, 9th ed., p. 44.

In all these species-or varieties-the leaf seems to be so rolled that the right edge comes over the left as the observer looks on the upper surface of the lamina ${ }^{1}$.

Another phenomenon common to all is the reflexion of the first leaf soon after the second leaf has unfolded. The mechanism of this reflexion has not, I believe, been explained.

It seems clear from the foregoing that no facts of sufficient morphological importance are forthcoming to enable us to separate the forms as good species, further than has been done on the other botanical characters. Indeed the 'seeds' and seedlings support very strongly the view adopted by Bentham that these species and varieties all graduate one into the other.

B. brizaeformis, Fisch and Mey.

Is a Caucasian and Persian species. It is put in the Serrafalcus section by Boissier, a view completely supported by examination of the 'seeds.'

$B$. brizaeformis is a remarkable form. Its widely spread palea and flattened form give it the resemblance to Briza, whence the name. Length about 9 , breadth $5 \mathrm{~mm}$. There is no awn, the membranous, 7-9 veined smooth palea cut into lobes at the apex. Colour pale-yellowish, with the large flat brown ovate caryopsis shining distinctly. Rachilla short.

My specimens of B. brizaeformis germinated well, twentyone out of twenty-five having come up on the sixth day.

B. macrostachys, Desf.

Occurs in the Mediterranean region, and is placed by Bossier near $B$. brizaeformis, from which it differs in several respects in addition to being awned.

$B$. macrostachys is a well-marked form with a silky-woolly tomentum all over the 'seed,' and the awn ( $15^{-18} \mathrm{~mm}$.) arising sub-terminally from the base of two teeth $(4-5 \mathrm{~mm}$.

\footnotetext{
1 See p. 308 for explanation.
} 
long) of the palea. Total length of 'seed' without awn I 3-14 $\mathrm{mm}$. : breadth about $3 \mathrm{~mm}$. The awn ascends with a curved base, and the woolly 'seeds,' remaining adherent in the spikelet, stick together. Rachilla stout and woolly. I found $B$. macrostachys germinate very slowly and badly. Only five out of twenty-four had germinated in six days.

\section{(4) Libertia.}

B. arduennensis. I have as yet had no opportunity of experimenting with this species, which stands alone as the only member of its group, and so am compelled to leave out of account all reference to this group in the sequel.

\section{(5) Ceratochloa.}

B. unioloides. B. Schraderi.

B. unioloides, $\mathrm{H}$. B. and $\mathrm{K}$.

Is a species from the hotter parts of America. It is an ornamental plant, and, though valuable as fodder in warm lands, easily freezes in the north. It is common from British Columbia to Patagonia and Juan Fernandez, and is widely

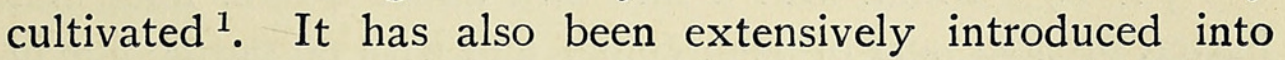
South Africa, Australia, and Tasmania ${ }^{2}$. I have not as yet had sufficient material for a thorough examination of the species in detail, but the following appears to be, as it is accepted as being, the same species with, possibly, slight varietal differences.

\section{B. Schraderi, Kunth.}

B. Schraderi, Kunth, is the same as B. unioloides, H. B. and K., according to Index Kervensis-Cf. Kunth, Enum. Pl. i. 4I6, and H. B. and K., Nov. Gen. et Sp. i. I5I.

The seed is laterally compressed, the palea being closed like a mussel-shell, and smooth and much veined. 15-16 $\times$ $2 \cdot 5-3 \mu$ the awn a mere point I $\mathrm{mm}$. long. In the mass pale

1 Hemsley in Challenger Report.

${ }^{2}$ See an excellent short account by Maiden in Agr. Gaz. of N. S. Wales, Dec. 1898 . 
yellow-grey. The shape of the 'seed' makes it lie on the side, and not as in so many on the flattened back.

My samples germinated slowly, and not very well. Of twenty-two 'seeds' sown, only eleven had put forth root-hairs in five days, though on the sixth day twenty were showing signs of germination: of these, however, only five had put out a spear.

In addition to these I have examined, less thoroughly as yet, the following.

B. giganteus is of the $B$. sterilis or $B$. madritensis type but with the five nerves of the palea well marked. It is $12-13 \mathrm{~mm}$. long, excluding the two fine papery teeth $2-3 \mathrm{~mm}$. and awn I4-1 $5 \mathrm{~mm}$. and about I mm. broad. Duller grey-yellow than any of the above. B. giganteus, L., is a native of Europe and Siberia. It is frequently regarded as-or, possibly, confounded with-a Fescue-Festuca gigantea (Vill.).

It is being cultivated for further examination.

\section{'B. pratensis.'}

Is a form very like a depauperate variety of $B$. arvensis, 6-6.5 $\times 1.75^{-2} \mathrm{~mm}$. with a fine awn about $4 \mathrm{~mm}$. long, but flatter, broader, and of paler colour, and with no purple hue in the mass. It is much smaller than $B$. racemosus and quite different from $B$. evectus, but as there was another form mixed with it, I defer judgement until later.

$B$. pratensis according: to the Index Kewensis is a synonym for $B$. racemosus or $B$. erectus, both of which differ in my samples from the 'seeds' received under this name.

\section{'B. ciliaris,' Torr.}

Was received under this name, but as yet I have been unable to trace it satisfactorily, and am cultivating it for further determination ${ }^{1}$.

$B$. ciliaris, Torr., resembles $B$. tectorum, so $\times 1 \mathrm{~mm}$, awn

1 It seems probable that this is wrongly named, and was sent over by a collector who made some error: I have been unable to trace the name in the literature (see p. 246). 
I6-I7 mm., the purplish 'seeds' remaining adherent in the spikelet, \&c., as before. Perhaps the 'seed' is a trifle more pubescent, but I can detect no essential difference.

$B$. ciliaris germinated freely, seventeen out of nineteen sown having come up well in five days.

\section{The Germination of the Bromes.}

It was necessary, at a certain stage in the experiments, to obtain some information as to the germinating capacity-in the sense in which this term is used by nurserymen and experts—of the 'seeds.'

To do this I employed ordinary Petri-dishes, with a filterpaper above and below, and sowed the 'seeds' on the lower paper. When the first root-hairs ${ }^{1}$ form, the seed becomes firmly adherent to the paper, and many advantages can be taken of this fact. For instance, it is easy to lift the germinating seedling up with forceps, by tearing the wet paper, and so transfer the whole bodily to a tube, \&c.; and since the radicle rapidly pierces the paper in many cases, this procedure often obviates any rupture of the delicate roots and root-hairs.

Such seedlings in dishes are extremely geotropic and heliotropic, and it is easy to take advantage of this fact when infecting the first leaf of the plumule. If the Petri-dish is left flat, the green leaf curves up and soon presses against the lid, and if spores are sown on the leaf the film of water between leaf and lid is of advantage in the germination of the spores. In obtaining infected leaves for hardening and subsequent section-cutting it is useful to have the seedlings quite straight. This is easily done by laying the 'seeds' with their axes parallel and apices all turned one way. As soon as the radicle begins to emerge, and the first root-hairs have fixed the seedling, the whole dish can be placed vertically on its edges, and so illuminated that root and shoot grow out in one straight line-the axis of the 'seed.' The plumule can

1 These first hairs would be more properly described as anchoring-hairs; they are developed not from the root but from the coleorhiza surrounding it. 


\section{Ward.-On Relations between Host and Parasite}

also be thus compelled to grow on in contact with the damp filter-paper and not lift itself off from the spores shed on the leaves, by geotropic or other curving.

The annexed tables I and II will give an idea of the germination capacity of the principal species used.

\section{TABLE I.}

Exp. No. 7 10. Germination of 'seeds' sown on damp filter-paper in Petri-dishes, sterilized by steaming. Incubated at $17 \cdot 5^{\circ} \mathrm{C}$, rising to $20^{\circ} \mathrm{C}$.

\begin{tabular}{|c|c|c|c|c|c|}
\hline No. & Date. & Seed sown. & Treatment. & $\begin{array}{l}\text { Date of } \\
\text { germination. }\end{array}$ & $\begin{array}{c}\text { Degree of } \\
\text { germination. }\end{array}$ \\
\hline $710 a$ & June I 2 & B. mollis & $\begin{array}{c}\text { Filter-paper at I } 7- \\
20^{\circ} \text { in incubator }\end{array}$ & I 5 & Good \\
\hline,,$b$ & , & B. velutinus & , & 16 & , \\
\hline,$c$ &, & B. maximus & , & I6 & 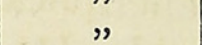 \\
\hline , d & $"$ & B. sterilis & " & I 5 & , \\
\hline,$" e$ & ", & B. madritensis & , & I 5 & , \\
\hline , $f_{0}$ & ", & $\begin{array}{l}\text { B. asper } \\
\text { B. commutatus }\end{array}$ & , & $\begin{array}{l}\text { o* } \\
\text { o* }\end{array}$ & $\begin{array}{l}0 \\
0\end{array}$ \\
\hline$" h$ & , & B. arvensis & 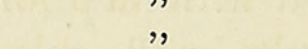 & I 5 & Good \\
\hline,$\quad i$ & , & B. secalinus & , & I6 & " \\
\hline,$k$ & , & B. interruptus &, & I6 & $"$ \\
\hline,,$l$ & ," & B. racemosus & , & I 5 & , \\
\hline
\end{tabular}

* Did not germinate.

TABLE II.

Exp. Nos. 745 and 746 . Germination of 'seeds' on damp filter-paper in Petri-dishes, at $20^{\circ}-23^{\circ} \mathrm{C}$.

\begin{tabular}{|c|c|c|c|c|c|c|c|c|}
\hline No. & Date. & Seed sown. & Treatment. & $\begin{array}{l}\text { No. } \\
\text { sown. }\end{array}$ & $\begin{array}{c}\text { No. } \\
\text { germinated. }\end{array}$ & $\underset{\%}{A p p r o x}$. & $\begin{array}{l}\text { Date of } \\
\text { germination. }\end{array}$ & $\begin{array}{c}\text { Height. } \\
\text { on } 6 \text { th day. }\end{array}$ \\
\hline 745 & July 3 & B. Schraderi & $\begin{array}{c}\text { on damp filter- } \\
\text { paper Normal } \\
t_{0}=23^{\circ} \mathrm{C} \text {. }\end{array}$ & 22 & 20 & 9 I & July 6 & \\
\hline ", & $\|$ & B. tectorum & , & 25 & 16 & 64 & July 5 & $10 \mathrm{~mm}$. \\
\hline ", & $"$ & B. ciliaris & $"$ & 19 & I 7 & 90 & 1 & $20-30 \mathrm{~mm}$. \\
\hline$"$ & $"$ & B. macrostachys & " & 24 & 5 & $2 \mathrm{I}$ & July 8 & \\
\hline , & $"$ & B. brizaeformis & $"$ & 25 & 2 I & 84 & July 6 & $5 \mathrm{~mm}$. \\
\hline ", & ", & B. erectus & $"$ & 34 & $\circ$ & o & $\circ$ & $\circ$ \\
\hline & , & B. canadensis & ", & 19 & 5 & 26 & July 6 & \\
\hline ," & " & B. aspe & ", & $3^{2}$ & 0 & $\circ$ & 0 & $\circ$ \\
\hline$"$ & & B. inermis & $"$ & 41 & I3 & $3 \mathrm{I}$ & July 6 & $\mathrm{I}-2 \mathrm{~mm}$. \\
\hline$"$ & July 5 & B. sterilis & $"$ & 6 & 6 & 100 & July 7 & $20 \mathrm{~mm}$ \\
\hline " & $"$ & B. maximus & $"$ & 6 & 6 & 100 & ", & \\
\hline & " & B. madritensis & $"$ & 6 & 6 & 100 & & \\
\hline $74^{6}$ & ", & B. pratensis & $"$ & $5^{6}$ & I 2 & $2 I$ & July 8 & \\
\hline 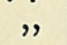 & ", & B. giganteus & $"$ & 24 & o & $\circ$ & 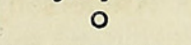 & \\
\hline
\end{tabular}


In devising some way of killing any possible Uredo-spores attached to the paleae or caryopsis, a few obstacles occurred owing to the difficulty of wetting the dry 'seeds' and the small size of the latter. Perhaps now that we know the maximum temperature for the spores (see p. 269), the best of all antiseptic measures will turn out to be careful heating in the dry state: this point needs further examination. As matter of fact I got good results by heating the seeds to $65-70^{\circ} \mathrm{C}$ in water: they will not stand $80-85^{\circ} \mathrm{C}$. The temperature of $65-70^{\circ} \mathrm{C}$ appears to be quite fatal to all Uredo-spores.

I attempted to get over the difficulty of penetration of the micropyle, \&c., by putting the 'seeds' in various liquidschloroform, carbolic acid, mercuric chloride, \&c.-and placing in a quickly acting air-pump and exhausting rapidly. As Table III shows, some success results, but great care is necessary to avoid damaging the radicle. Possibly more success will yet be met with in a longer series of trials, but I got very good results with chloroform. On the whole, however, heating to $70^{\circ} \mathrm{C}$ seemed most satisfactory.

\section{EXPERIMENTS ON TEMPerature.}

It seems surprising that we know practically nothing about the temperature of a leaf in the sunshine, yet such appears to be the case. A few observations have been made by placing thermometers with their bulbs stuck in the tissues of fleshy plants, such as Cacti, \&c. ${ }^{1}$, but these hardly bear on the question concerning leaves, though they give us an insight into the subject of the high temperatures plant-tissues generally may withstand.

Again, Keeble's experiments ${ }^{2}$ only bear indirectly on what we are here interested in: moreover they refer to tropical trees.

Darwin, in his admirable memoir on Stomata ${ }^{3}$, has one or two records of leaf temperatures in Tropaeolum, but he gives no observations showing what temperatures are reached by

1 Ascherson, Bot. Zeit.

2 Ann. Bot., vol. ix, I895, p. 59.

${ }^{3}$ Phil. Trans., 1898, vol. 190, p. 531. 


\section{TABLE III.}

Exp. Nos. 740, 743. Germination of 'seeds,' sterilized in various ways (col. 4). All started in incubator at $20-22^{\circ} \mathrm{C}$.

\begin{tabular}{|c|c|c|c|c|c|c|c|}
\hline $\begin{array}{l}\text { Exp. } \\
\text { No. }\end{array}$ & Date. & Seed sown. & Treatment. & Time. & $\begin{array}{l}\text { No. } \\
\text { sown. }\end{array}$ & $\begin{array}{l}\text { No. which } \\
\text { germinated. }\end{array}$ & $\underset{\%}{A p p r o x .}$ \\
\hline 740 & June 29 & B. sterilis (1) & $5 \%$ Carbolic & $5 \mathrm{~min}$. & I 7 & I3 & 80 \\
\hline ", & " & " (2) & I $7 \mathrm{HgCl}_{2}$ & & 23 & I 7 & 74 \\
\hline " & ", & $" \quad(3)$ & Boiled up & Just boiled & 24 & o & ○ \\
\hline$"$ & ", & (4) & Scalded & Rapidly cooled & $2 \mathrm{I}$ & 0 & $\circ$ \\
\hline . & & $",{ }^{(5)}$ & None & [Control] & 24 & 23 & 96 \\
\hline 743 & July 2 & B. mollis (6) & Satd. $\mathrm{HgCl}_{2}$ sol. & $5 \mathrm{~min}$. & $5 \mathrm{I}$ & I5 & 30 \\
\hline$"$ & $"$ & $" \quad(7)$ & $"$ & $\begin{array}{l}\text { Io min. includ- } \\
\text { ing exhaustion }\end{array}$ & 35 & 0 & 0 \\
\hline " & ", & (8) & & $30 \mathrm{~min}$. ditto & 25 & o & o \\
\hline$"$ & $"$ & $" \quad(9)$ & 5\% Carbolic & $5 \mathrm{~min}$. & 50 & 0 & o \\
\hline$"$ & $"$ & $" \quad(10)$ & & $\begin{array}{l}\text { I0 min. includ- } \\
\text { ing exhaustion }\end{array}$ & $3^{I}$ & o & 0 \\
\hline ", & ", & „ (11) & Pure chloroform & ditto & $4 \mathrm{I}$ & I 7 & $4 \mathrm{I}$ \\
\hline " & " & " (12) & Scalded & Rapidly cooled & 49 & 0 & 0 \\
\hline$"$ & $"$ & " (13) & Raised to $85^{\circ} \mathrm{C}$ & " & $5^{8}$ & $\circ$ & $\circ$ \\
\hline$"$ & $"$ & $" \quad(14)$ & $75^{\circ} \mathrm{C}$ & $"$ & 53 & 3 & 6 \\
\hline , & ", & $"$ " (16) & & [Control] & $\begin{array}{l}5^{2} \\
35\end{array}$ & $\begin{array}{l}50 \\
35\end{array}$ & $\begin{array}{r}90 \\
100\end{array}$ \\
\hline
\end{tabular}

$(1,2)$ Simply steeped and shook up.

(3) Brought rapidly to the boil and quickly cooled.

(4) Plunged into boiling water and rapidly cooled.

(6) Steeped and shook up.

(5) Control.

(7) Put under pump and forced in and washed quickly.

(8) Put under pump, \&c., and left steeping. (9) Steeped and shook up.

$(10,11)$ Put under pump and forced in and washed.

(12) Poured boiling water on and at once cooled.

(13-15) Raised to temp. given and quickly cooled.

(16) Control.

leaves of plants, such as grasses, \&c., in direct sunshine in the summer.

In order to see if I could obtain any information on this obscure question I started a number of observations with thermometers. One was placed with its bulb resting among the leaves of a tuft of $B$. maximus, so arranged that it was clear of the soil, and well in the shade of the numerous leaves as the sun shone on to the tuft.

By the side of the tuft another thermometer was laid across supports which held it at about the same distance from the soil, the bulb as free as possible in the air. 
A third thermometer was hung vertically in the air, well away from the thin glass rod which supported it by a thread, and which was stuck in a pot of soil.

A fourth thermometer with blackened bulb was similarly suspended from another thin glass rod.

And, finally, a similarly suspended thermometer with a long but narrow thin bulb-one of those which I use for inserting into glass cells in which hanging drops are cultivated - was so arranged that the bulb was wrapped in the broad leaves of $B$. maximus, and thus protected from the direct rays of the sun by the thickness of a single leaf.

Various readings were taken on different days, of which the following may be given (Tables IV, V, and VI). It is not claimed that this method gives perfectly accurate results, but it shows quite clearly the kind of temperatures which may be expected in the closed glass vessels in which the spores are put to germinate on the leaves; and even if it is contended that it will not give the exact temperature of the leaf-surface on which the spores are sown, we may fairly assume that it does show an approach to it, and at any rate demonstrates that such leaves may be heated up to temperatures far above the maximum for spore-germination or that which the germ-tubes can withstand, without themselves being damaged.

I am of opinion that more accurate records with a thermopyle will show that the leaves in direct sunshine are heated up to temperatures far higher than is usually assumed.

\section{The Germination of the Uredospores.}

The germination of the spores-Uredo-spores-is as a rule easily brought about in water, distilled or tap water, but many observers have remarked the curious uncertainty sometimes met with in their behaviour. I have paid some attention to this matter, with a view to discover if possible what are the conditions which dominate the capacity for germination.

In a good batch of spores, signs of germination in water 
TABLE IV. Readings of thermometers to show approximate temperature in leaves exposed to direct sunshine in greenhouse with lights open. Facing west.

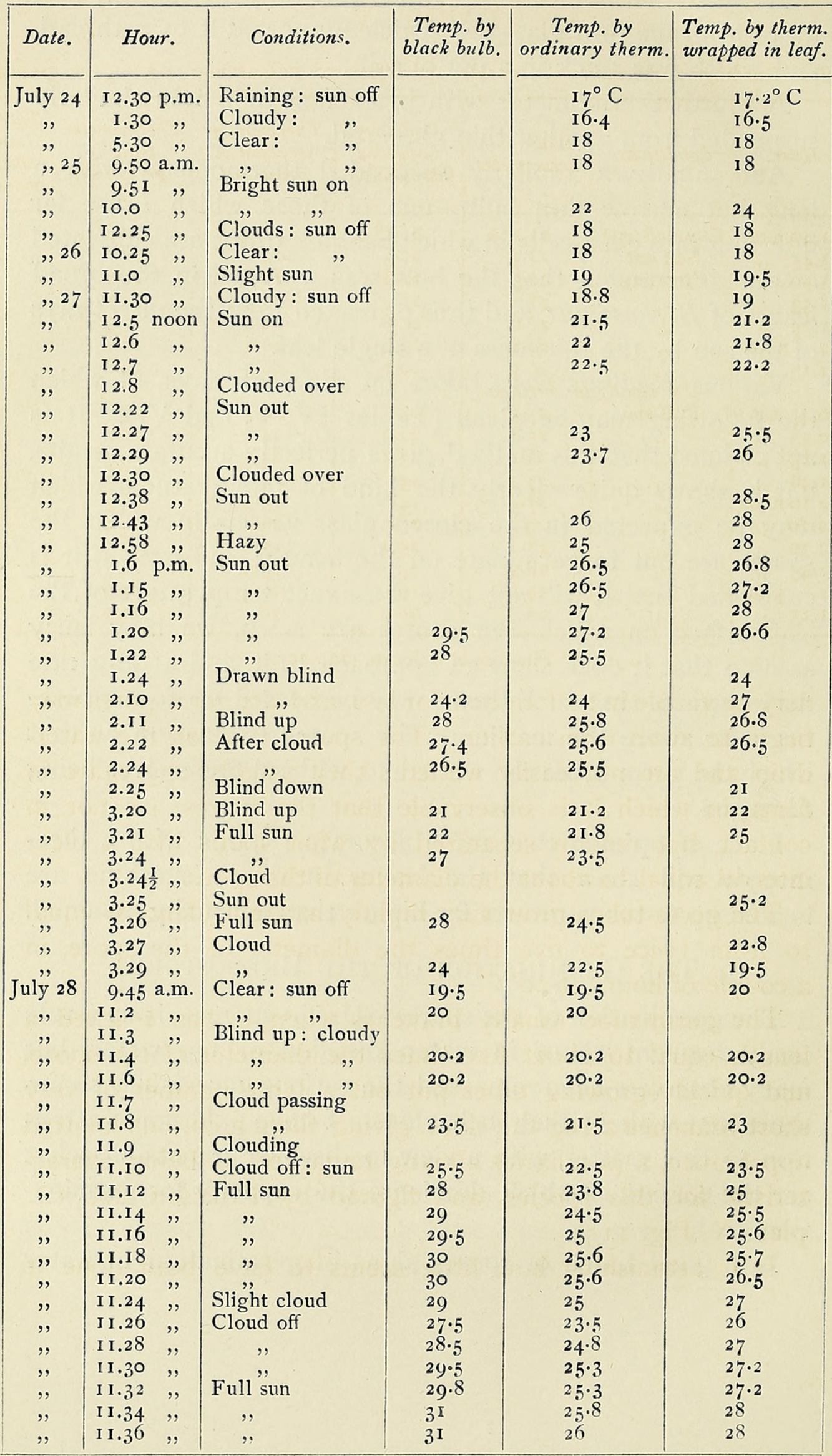




\section{in the Bromes and their Brown Rust. 263}

TABLE V.

Exp. No. 785. Readings of thermometers outside, and compared with ordinary readings on grass and in air.

\begin{tabular}{|c|c|c|c|c|c|c|c|}
\hline Date. & Hour. & Conditions. & $\begin{array}{c}\text { Black bulb } \\
\text { thermometer. }\end{array}$ & $\begin{array}{c}\text { Ordinary } \\
\text { suspended } \\
\text { thermometer. }\end{array}$ & $\begin{array}{c}\text { Thermometer } \\
\text { wrapped in } \\
\text { grass-leaf. }\end{array}$ & $\begin{array}{c}\text { Thermometer } \\
\text { lying in } \\
\text { grass-tuft. }\end{array}$ & $\begin{array}{l}\text { Thermometer } \\
\text { suspended } \\
\text { horizontally } \\
\text { above ground. }\end{array}$ \\
\hline July 28 & II. 40 a.m. & Clouded over & $2 \mathrm{I} \cdot 2^{\circ} \mathrm{C}$ & $2 \mathrm{I} \cdot 2^{\circ} \mathrm{C}$ & $2 \mathrm{I}^{\circ} \mathrm{C}$ & $20.6^{\circ} \mathrm{C}$ & $2 \mathrm{I} \cdot 1^{\circ} \mathrm{C}$ \\
\hline , & I I.45 , , & Sun out & $24 \cdot 5$ & $22 \cdot 5$ & 23 & $2 I$ & 24 \\
\hline$"$ & I I.50, & Clouding & 22.5 & $2 \mathrm{I} \cdot 6$ & $2 \mathrm{I} \cdot 8$ & $2 \mathrm{I} \cdot 2$ & 22 \\
\hline ", & II.53 , & , & 2 I & 2 I & 20.9 & 20.5 & $2 \mathrm{I} \cdot 5$ \\
\hline ", & II.55, & , & 20.6 & 20.8 & 20.5 & 20.4 & $2 \mathrm{I} \cdot 5$ \\
\hline , & 12 noon & , & 20.6 & 20.6 & 20.6 & 20.2 & $2 I$ \\
\hline$"$ & I $2.15 \%$ & Too cloudy & $\begin{array}{c}20.5 \\
\text { to continue }\end{array}$ & $20 \cdot 6$ & 20.5 & $19 \cdot 8$ & 20.8 \\
\hline July 29 & I 0.45 a.m. & Full sun & $\quad 25.5$ & 23 & $24 \cdot 5$ & 24 & 23 \\
\hline ", & 10.55, & , & 25.8 & $22 \cdot 9$ & 24 & $22 *$ & $24 \cdot 3$ \\
\hline , & II.I5, &, & $26, I$ & $23 \cdot 5$ & $23 \cdot 5$ & I9. $5^{*}$ & $19.9^{*}$ \\
\hline , & II.40 , , & , & 27 & $24 \cdot I$ & 24 & $23 \cdot 5$ & $24 \cdot 3$ \\
\hline ", & I2.10 noon & , & $27 \cdot 4$ & $24 \cdot 6$ & $25 \cdot 5$ & 24.5 & 25 \\
\hline ", & I 2.20, & , & 29 & $25 \cdot 5$ & $26 \cdot 2$ & $24 \cdot 9$ & $26 \cdot 6$ \\
\hline " & I 2.30, & , & 28.2 & $25 \cdot 4$ & $25 \cdot 8$ & 26 & $27 \cdot 8$ \\
\hline , & I 2.45, & , & $28 \cdot 2$ & 25 & 25.9 & 26 & $27 \cdot 5$ \\
\hline , & I p.m. & , & $29 \cdot I$ & 26 & 26.4 & 25.6 & 28 \\
\hline , & I.I 5, & , & 28 & 25.9 & 26 & $25 \cdot 2$ & 27 \\
\hline
\end{tabular}

* Shadow of a distant chimney.

may be visible in half an hour or less, and the germ-pores may begin to swell even earlier. The spores float on the waterdrop and are not easily wetted: they usually aggregate in films, in which it is observable that the spores are not in contact, but remain separated by what looks like a clear interval equal to about the diameter of the spore.

The germ-tubes grow very rapidly, attaining lengths equal to from twice to five times the diameter of the spore, in a couple of hours at $20^{\circ} \mathrm{C}$.

The germ-tube usually branches when it has reached a length equal to about five times the diameter of the spore, and quickly-growing tubes put out a large number of very short branches along the sides, giving them a curious knotted appearance, a peculiarity already remarked as being characteristic for this species, and figured by Eriksson (loc. cit., plate X, Fig. II 5 ).

It is astonishing how little seems to have been done in 
264 Ward.-On Relations between Host and Parasite

\begin{tabular}{|c|c|c|c|c|}
\hline \multirow{8}{*}{ 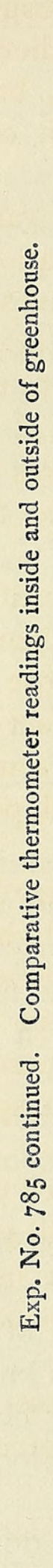 } & 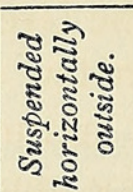 & 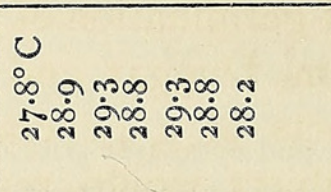 & & $\ddot{\text { ה }}$ \\
\hline & 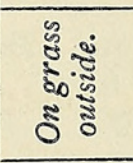 & 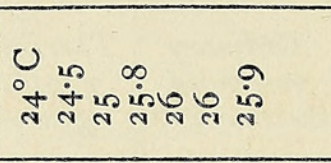 & & 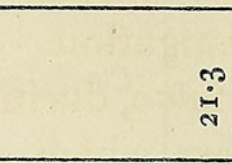 \\
\hline & 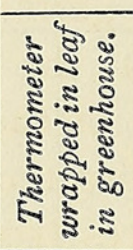 & 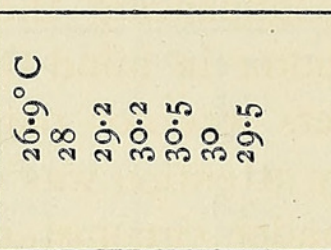 & 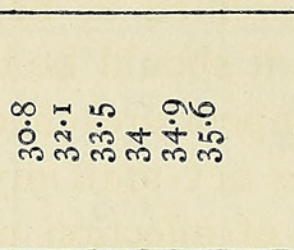 & రஸ் \\
\hline & 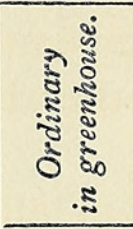 & 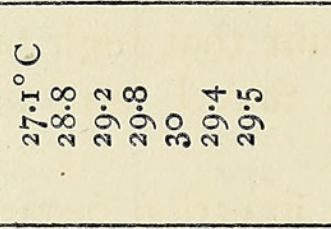 & 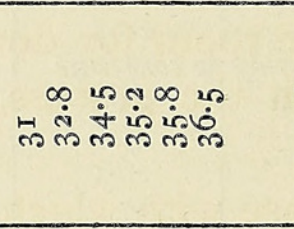 & 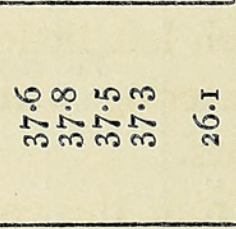 \\
\hline & 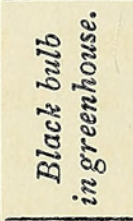 & 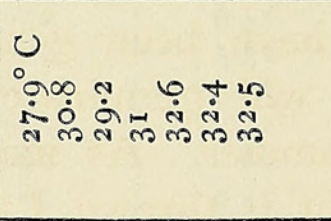 & m & 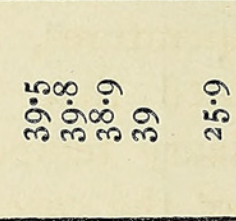 \\
\hline & : & 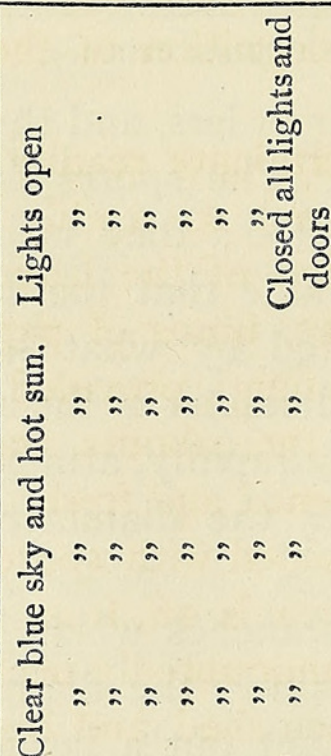 & 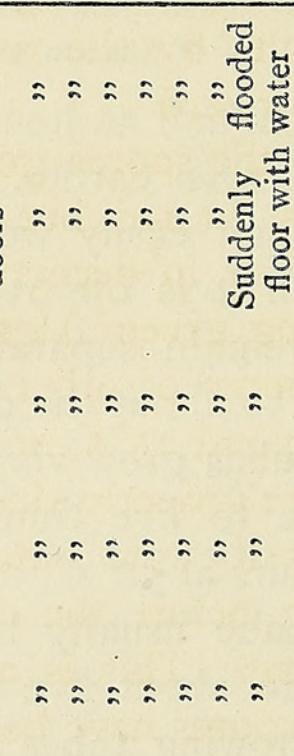 & 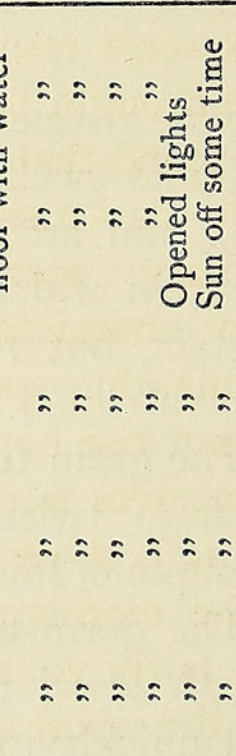 \\
\hline & 今ั & 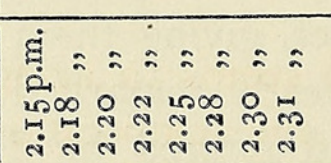 & 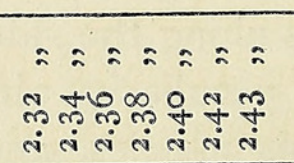 & 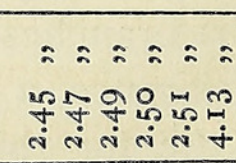 \\
\hline & ธัँ & $\frac{a}{a}=2=2=2=$ & $=2 x=2=2$ & $=2=2=$ \\
\hline
\end{tabular}




\section{in the Bromes and their Brown Rust. 265}

ascertaining the conditions of germination of the Uredospores. De Bary, Plowright, Eriksson, Duggar and a few other observers have given some facts of a general nature, but it seems probable that the subject would repay much closer investigation.

I have, during the course of the experiments, tested various factors which seemed to be influencing the germination of the spores, but it should be borne in mind that the investigation of the temperature effects was not part of the original plan, and it was not until my attention was directed to them by the failure of infection under circumstances (see p. 291) which left little room for doubt that high temperatures were interfering with the process, that I went further into these points.

From the ease with which infection occurs at all ordinary temperatures, it seems to have been generally taken for granted that Uredospores will germinate at almost any ordinary temperature in Summer. As matter of fact this is not the case, and new light is thrown, I think, on some of Eriksson's results by the recognition of the cardinal points here brought forward.

I found that the spores germinate readily in ordinary light or in darkness, in red but not so readily in blue light, in ordinary water or in decoction of the leaves of Bromus, in water containing green Algae, fibres of paper-pulp, or even germinating spores of other fungi, provided the temperature did not rise beyond $25^{\circ} \mathrm{C}$ or thereabouts, and that the spores themselves were properly ripened and fresh.

The best results were obtained with spores gathered early in the morning, before the dew is off, from leaves still green and fairly young. This is undoubtedly because later in the day the ripest spores have been shed, and because exhaustion has set in on older leaves.

The following Table (VII) seems to bring out these conclusions very clearly, though the temperature of germination is somewhat high for the species.

In reply to the criticism that the non-germination of Uredo- 


\section{TABLE VII.}

Exp. No. 737. Results showing the comparative germination of spores of different ages.

\begin{tabular}{|c|c|c|c|c|c|c|}
\hline No. & $\begin{array}{l}\text { Date } \\
\text { sown. }\end{array}$ & $\begin{array}{l}\text { Origin of } \\
\text { spores. }\end{array}$ & $\begin{array}{l}\text { A ge of } \\
\text { leaf. }\end{array}$ & State of leaves. & $\begin{array}{c}\text { State of spores } \\
\text { sown. }\end{array}$ & Temp. \\
\hline $\begin{array}{c}737 a^{a} \\
, a^{\prime}\end{array}$ & $\begin{array}{c}\text { June } 27 \\
\text { " }\end{array}$ & $\begin{array}{c}\text { B. mollis }(1) \\
, \quad(2)\end{array}$ & $\begin{array}{c}\text { Young } \\
, "\end{array}$ & $\begin{array}{c}\text { Fresh } \\
, "\end{array}$ & $\begin{array}{l}\text { Naturally shed } \\
\text { Scraped off after }\end{array}$ & $\begin{array}{c}24^{\circ}-25^{\circ} \mathrm{C} \\
\prime \prime\end{array}$ \\
\hline & & & & & the shedding & \\
\hline$" b$ & $"$ & (3) & Old & $\begin{array}{l}\text { Kept } 24 \text { hours } \\
\text { in moist box }\end{array}$ & $y$ shed & $"$ \\
\hline$" \quad b^{\prime}$ & $"$ & $\begin{array}{l}(4) \\
(5)\end{array}$ & $\begin{array}{l}\text { Young } \\
\text { Old }\end{array}$ & $"$ & Scraned & $"$ \\
\hline & $"$ & & & " & shedding & $"$ \\
\hline$" b^{\prime \prime \prime}$ & $"$ & ", $(6)$ & Young & & & " \\
\hline $\begin{array}{ll}" & c \\
& c^{\prime}\end{array}$ & ", & $\begin{array}{c}\text { B. sterilis (7) } \\
, \quad(8)\end{array}$ & ", & $\begin{array}{c}\text { Fresh } \\
, ",\end{array}$ & $\begin{array}{l}\text { Naturally shed } \\
\text { Scraped after }\end{array}$ & $"$ \\
\hline , $c^{\prime \prime}$ & $"$ & (9) & Old & $"$ & $"$ & $"$ \\
\hline
\end{tabular}

(1) Germinated vigorously in 3 hours.

(2) None germinated even in 24 hours.

(3) Only one or two germinated. Several other fungus spores were present.

(4) Germinated vigorously in 3 hours.

(5) None germinated, even in 24 hours. Many spores of other fungi present.

(6) None germinated, though the spores appeared clean.

(7) Vigorous germination in 3 hours.

(8) Also germinated fairly well.

(9) None germinated.

spores in certain cases might be due to the presence of the spores of other fungi, e.g., moulds, Dematium, \&c., while something may no doubt be put down to their agency in robbing the hanging drops of oxygen, and interfering in other ways with the well-being of the Uredospores; I obtained plenty of evidence showing that this is but a minor event in cases where the latter spores are capable of rapid germination: they can hold their own very well in the race for some hours at least, and on green leaves in the open are not likely to be injured by competing saprophytes.

The following Table (VIII) shows the result of a few experiments typical of several others made to test the action of light. Though the number of trials is as yet too few to base any very wide generalization on, the positive results are useful, and clearly point to the conclusion that no ordinary light affects the germination very seriously; and even in the 


\section{TABLE VIII.}

Nos. $753,694,695,698,699$. Experiments to test the effects of light on the germination of the Uredospores.

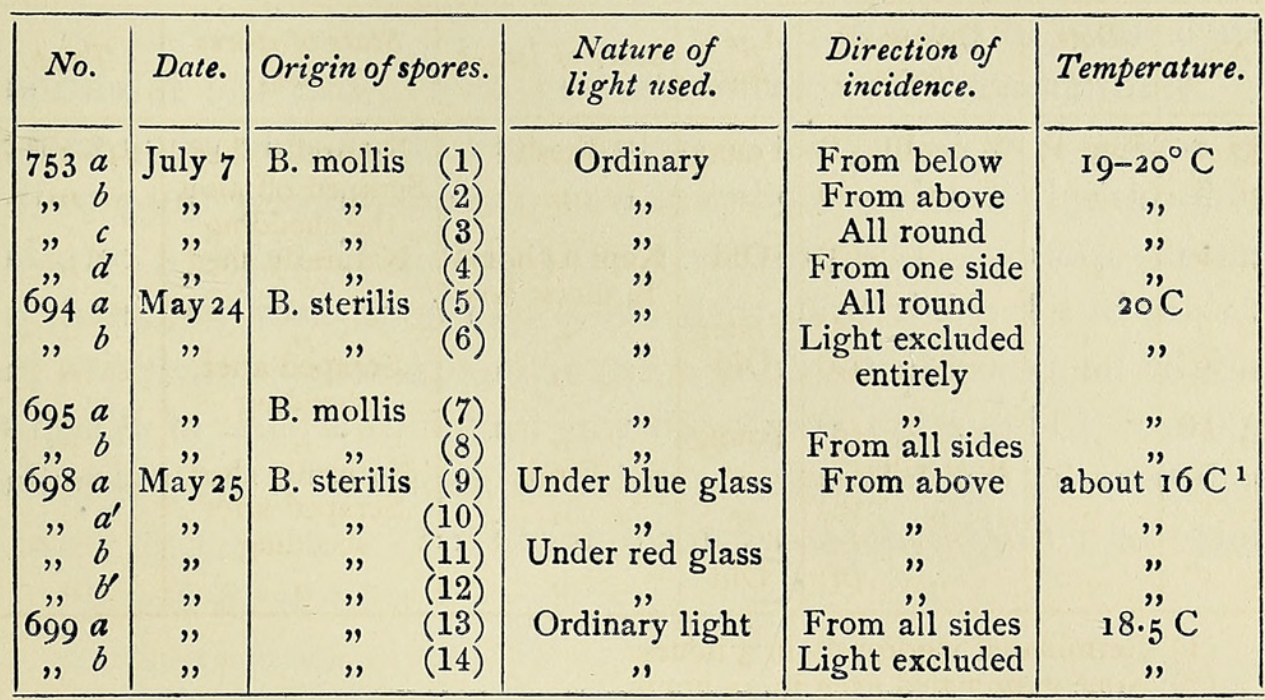

1 The variations of temperature seemed slight, but were not recorded continuously.

(1-4) Germinated well in an hour, and tubes turned chiefly downwards.

Numerous foreign fungus-spores present. In 3 hours vigorous.

(5) In 3 hours the germ-tubes were $2-5$ times the spore-diameter in length.

(6) Germination not quite so vigorous but still very good.

$(7,8)$ Similar results.

(9) In 24 hours only I spore germinated of $5^{8}$ in the drop.

(10) In 24 hours none germinated of I I 4 spores.

(11) In 4 hours tubes 5-8 times the spore-diameter in length. In 24 hours about $\mathrm{I} 5 \mathrm{O}$ spores of some 200 have germinated.

(12) Germination begun in 4 hours. In 24 hours about 20 out of 120 had germinated: drop drying up.

(13) Several spores have tubes twice the spore-diameter in length in 4 hours.

(14) At least one spore germinated equally well.

case of the light through blue glass I am inclined to suspect that carefully extended observations may show that the effects are but slight - that the orange-yellow cell contents protect the protoplasm from the action of the blue rays. Nevertheless, there seems to be some slight inhibiting action worth further examination. The chief difficulty will be to get comparative results at similar temperatures.

My reasons for varying the direction of incidence of the light in certain cases were based on some results (as yet 
inconclusive) that the germ-tubes exhibit heliotropic curvatures: this question demands closer inquiry.

It will also be seen from the Table that the spores germinate in the dark as well as in the light, a fact already known for such fungi in general.

Another set of experiments was made with the intention of seeing if any suggestive results were obtainable when some chlorophyll-bearing organism was present among the germinating spores. The positive results (Table IX) have a certain value, but I think that with the experience now obtained, it might be possible to design experiments more conclusive in nature. The Alga employed was found in a flask of Knop's solution in my laboratory, and was apparently the palmella form of a Chlamydomonas not determined.

\section{TABLE IX.}

Exp. No. 7or. Results of cultures in presence of a chlorophyllbearing Alga compared with the same in absence of the Alga.

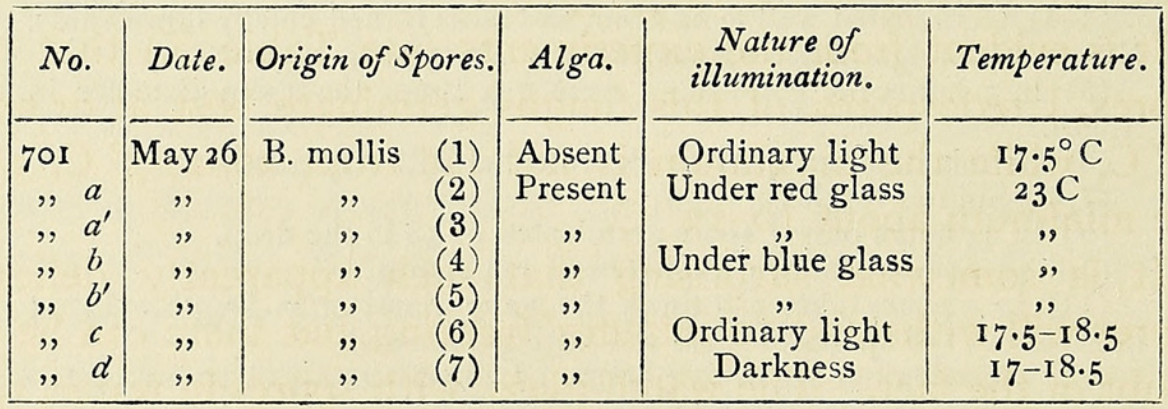

(1) Germinated well in 4 hours.

(2-5) None germinated in 4 hours, but in 24 several spores had put out tubes : (4) and (5) less vigorous.

(6) In 4 hours about $10 \%$ had tubes 4-6 times spore-diameter in length.

(7) In 4 hours about $50 \%$ had tubes 8-io times the sporediameter in length.

The net result is to show that the presence of such an Alga is not an important determining factor, for even under blue glass the spores sometimes germinated during the night. It should be noted that at the time these experiments were made I was not yet in possession of the facts concerning the critical temperatures, nor fully alive to the necessity of choosing recently ripened spores, and possibly other factors of im- 
portance were overlooked. Nevertheless it seems worth while noting the positive results.

The effects of different temperatures seem to be much more definite and important.

As regards methods there is little to remark beyond what is told in Table X. The simplest results are those in watchglasses of water, on the surface of which the spores were sown and the laboratory temperatures noted. In those cases where a definite temperature is given, however, the watchglass was placed in the incubator.

More accurate results are of course attainable in the cells; i. e. the spores were in hanging drops in culture-cells in the heated microscope culture-box, and in these cases the temperatures, regulated with thermostat, \&c., are those of the drop itself and its surrounding atmosphere.

In those cases where the word 'heated' is added, it is to be understood that the temperature of the culture-box was slowly raised accurately to the range given.

It is evident from the experiments (see Table $\mathrm{X}$ ) that the spores, Uredospores, of this fungus germinate best at or near $20^{\circ} \mathrm{C}$, while the maximum is not far from $26-27.5^{\circ} \mathrm{C}$, and the minimum about $10-12^{\circ} \mathrm{C}$.

It is somewhat surprising that such apparently delicate spores will withstand to minutes' freezing, but there can be no doubt of the fact. The watch-glass, with spores in water, was placed in an iced chamber, in a glass vessel surrounded by a freezing mixture, and the temperature, recorded by a small and delicate thermometer, went to $-5^{\circ} \mathrm{C}$, the mass freezing to a solid block of ice. A piece of this was chipped off and placed in a clean watch-glass at $20^{\circ} \mathrm{C}$, with the result given in the Table. The spores germinated in less than $7 \frac{1}{2}$ hours. The rest of the frozen spores, kept frozen for $4-5$ hours, could not be resuscitated. None of the spores heated to temperatures above $30^{\circ} \mathrm{C}$ could be resuscitated, and even $27.5^{\circ} \mathrm{C}$ was found to be a trying temperature in many cases.

It seemed desirable in view of certain eventualities referred to in section 16 to test the possibility of the leaf containing some 
270 Ward.-On Relations between Host and Parasite

TABLE $\mathrm{X}$.

Showing the effects of temperatures, maximum, minimum, and optimum, on the germination of spores.

\begin{tabular}{|c|c|c|c|c|c|c|}
\hline \multirow{2}{*}{$\frac{\text { No. }}{700 a}$} & \multirow{2}{*}{$\frac{\text { Date. }}{\text { May } 25}$} & \multicolumn{2}{|c|}{ Origin of spores. } & \multirow{2}{*}{$\frac{\text { Condition of spores. }}{\text { Fresh (wild) }}$} & \multirow{2}{*}{$\frac{\text { Further treatment, } \& c .}{\text { In watch-glasses }}$} & \multirow{2}{*}{$\frac{T e m p .}{17^{\circ} \mathrm{C}}$} \\
\hline & & B. mollis & (1) & & & \\
\hline$\Rightarrow b$ & $"$ & , & (2) & $"$ & $"$ & $"$ \\
\hline & $"$ & $"$ & (4) & $"$ & $"$ & $"$ \\
\hline$" \begin{array}{ll}\prime \prime \\
. & e\end{array}$ & $"$ & $"$ & (4) & $"$ & $"$ & $"$ \\
\hline$" f f$ & $"$ & $"$ & (6) & $"$ & $"$ & $"$ \\
\hline $7 \mathrm{II}$ & June 20 & , & (7) & $"$ & $"$ & $19-20$ \\
\hline 713 & +0 & " & (8) & " & ", & $"$ \\
\hline $\begin{array}{l}714 \\
716\end{array}$ & The & " & $(9)$ & Kent 5 days (wild) & " & 0 \\
\hline $\begin{array}{l}710 \\
720\end{array}$ & June 22 & $"$, & (11) & Kept 5 days (wila) & In cells & 25 \\
\hline$"$ & ", & ", & (12) & $" 5$ & " (heated) & 27.5 \\
\hline $7^{2} 3$ & $"$ & ", & (13) & $\Rightarrow 6$ & $"$ & 22 \\
\hline 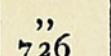 & In" & P ato" & (14) & , 6 ", & ", (heated) & $25^{-27} \cdot 5$ \\
\hline 720 & June 23 & B. steril1s & (15) & $\begin{array}{l}\text { Fresh (Irom experiment } \\
\left.707 d^{\prime \prime}\right)\end{array}$ & In cells & 22 \\
\hline 728 & June 25 & ," & $\begin{array}{l}(16) \\
(17)\end{array}$ & Fresh (garden) & ," & $\begin{array}{c}25-27 \cdot 5 \\
20\end{array}$ \\
\hline 729 & $"$ & P möllic & (18) & & " & " \\
\hline & Tune 26 & B. mollis & $(19)$ & Kept I day (wild) & $"$ & $"$ \\
\hline $\begin{array}{c}734 \\
, "\end{array}$ & June 20 & D. asper & $(21)$ & Fresh (garde & $"$ & $"$ \\
\hline 735 & June 27 & B. sterilis & (22) & " (wild) & ", & $\ddot{25}$ \\
\hline $73^{6}$ & 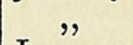 & B. mollis & $(23)$ & Kept I day (wild) & ", & $"$ \\
\hline $74 \mathrm{I}$ & June $3^{\circ}$ & B. secalinus & $(24)$ & Fresh (garden) & , & $"$ \\
\hline 744 & July 2 & & $(26)$ & Kept 2 days (garden) & In cells & $20-22$ \\
\hline 747 & July 6 & B. mollis & $(27)$ & Kept I day (wild) & " & $"$ \\
\hline 748 & $"$ & B. secalinus & $(28)$ & Fresh (exp. 713) & ", & $"$ \\
\hline & & B. velutinus & $(29)$ & $"$ & " & " \\
\hline 749 & Jaly 7 & B. interruptus & $5(30)$ & Kent I" (wild) & $"$ & $"$ \\
\hline $75 \mathrm{I}$ & 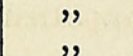 & oll1 & (31) & Kept I day (wild) & ", & $"$ \\
\hline 754 & July 8 & B. sterilis & (33) & ", & ", & $20-2$ \\
\hline 755 & July 9 & B. secalinus & $(34$ & (garden) & $"$ & $20-2$ \\
\hline 759 & July I 4 & B. mollis & $(35$ & (wild) & $"$ & $20-2$ \\
\hline
\end{tabular}

(1) Germinating well in 4 hours.

(3) Germinating well in 4 hours.

(5-6) Germinating well in 4 hours.

$(10,11)$ Germination feeble.

$(13,14)$ Germination feeble.

(16) Only one spore germinated.

(19) None germinated. Many moulds.

(21) None germinated. Much Dematium.

(27) Fairly good in 3 hours.

$(30-32)$ Very vigorous in 5 hours.

(35) Fairly vigorous.
(2) Traces of germination in 4 hours.

(4) Traces of germination in 4 hours.

(7-9) Vigorous germination.

(12) Germination very feeble.

(15) Very feeble.

$(17,18)$ Vigorous.

(20) Vigorous germination.

(22-26) Very vigorous.

$(28,29)$ Several spores germinated in 3 hours. $(33,34)$ Very vigorous in 2 hours. 
TABLE X (continued).

\begin{tabular}{|c|c|c|c|c|c|c|}
\hline \multirow{2}{*}{$\frac{\text { No. }}{{ }^{7} 760}$} & \multirow{2}{*}{$\frac{\text { Date. }}{\text { July } 14}$} & \multicolumn{2}{|c|}{ Origin of spores. } & \multirow{2}{*}{$\frac{\text { Condition of spores. }}{\text { Fresh (garden) }}$} & \multirow{2}{*}{$\frac{\text { Further treatment, } \& c .}{\text { In watch-glasses }}$} & \multirow{2}{*}{$\frac{T e m p .}{20-25^{\circ} \mathrm{C}}$} \\
\hline & & B. $s$ terilis & $(36)$ & & & \\
\hline$"$ & $"$ & $"$ & $(37)$ & " & " & " \\
\hline $7 \ddot{61}$ & " & B. mollis & $\begin{array}{l}(38) \\
(39)\end{array}$ & " & $"$ & . " \\
\hline 763 & July I 5 & P " & $(40)$ & Kept i day (garden) & $"$ & $23^{-26}$ \\
\hline $\begin{array}{l}704 \\
766\end{array}$ & July I 7 & $\begin{array}{l}\text { B. sterilis } \\
\text { B. mollis }\end{array}$ & $\begin{array}{l}(41) \\
(42)\end{array}$ & Fresh $(g$ & ", & $24-30$ \\
\hline & July I 8 & 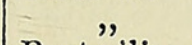 & $(43)$ & Same kept I d & $"$ & $24^{-25}$ \\
\hline 767 & July I 7 & B. sterilis & $(44)$ & Fresh (garden & ", & $24-30$ \\
\hline 768 & July I 8 & B. secalinus & $(45)$ & Same kept I day (g & In "ells & $24-25$ \\
\hline $77 \mathrm{I}$ & $"$ & , & $(47)$ & $"$ & $"$ (heated) & $26-30$ \\
\hline$"$ & July I 9 & $"$ & $\begin{array}{l}(48) \\
(49)\end{array}$ & Same kept I day (garden) & $"$ (heated) & $\begin{array}{c}18 \cdot 5 \\
26-30\end{array}$ \\
\hline & Iuly 20 & B m & $(50)$ & & & 18.5 \\
\hline 777 & July 23 & B. mollis & (51) & Kept 2 days ( $g$ & & $17-17 \cdot 6$ \\
\hline$"$ & ", & ", & $(53)$ & $"$ & ", (heated) & $27 \cdot 5-32$ \\
\hline$"$ & $"$ & " & $(54)$ & " & $"$ (on ice) & $3-4$ \\
\hline$"$ & $"$ & $"$ & $(55)$ & $"$ & $\begin{array}{l}\text { Watch-glass (on 1ce) } \\
\text { Cells (near ice) }\end{array}$ & $8=10$ \\
\hline " & $"$ & $"$ & (57) & $"$ & Cens (IIEAI ICe) & $9-10$ \\
\hline $779 a$ & July 24 & ", & (58) & Kept 3 days (garden) & Cells in light & 19 \\
\hline$\Rightarrow b$ & ", & , & $\begin{array}{l}(59) \\
(60)\end{array}$ & ”, & Cells (heated) & $33-26$ \\
\hline$" \alpha$ & $"$ & " & (61) & $"$ & $\begin{array}{c}\text { (frozen hard } \\
\text { minutes) }\end{array}$ & -5 \\
\hline $780 e$ & $"$ & B. secalinus & $\begin{array}{r}(62) \\
s(63)\end{array}$ & Fresh (garden) & $\begin{array}{l}\text { (frozen 4-5 hours) } \\
\text { Cells and watch-glasses }\end{array}$ & $\begin{array}{l}-5 \\
-5\end{array}$ \\
\hline " & $"$ & , & $(64$ & , & $" \quad$ " (heated) & $26-29$ \\
\hline " & ", & " & & $"$ & $"$ (on ice) & 6 \\
\hline
\end{tabular}

${ }^{1}$ It was the behaviour of this series which suggested to me to test the germination of the spore according to the age of the leaf, \&c.

(36) Vigorous germination.

(39) Fairly vigorous.

(43) Fairly vigorous.

(46) Very vigorous.

(48) Very vigorous. (49) None germinated.
(51) In I $\frac{1}{4}$ hours vigorous germination and tubes as long

(37) Poor.

$(40,41)$ Poor. $\quad(42)$ None germin
$(44)$ None germinated : as if paralysed.

(47) None germinated: as if paralysed.

(50) Very vigorous.

iameters and branching: in 7 hours $12-20$ diameters and much branched.

(52) Very vigorous in both light and dark. In $I \frac{I}{2}$ hours tubes $=I-2$ spore diameter: in

3 hours $=6-8$ diameters and branching. In 7 hours $=12-20$ diameters and much branched.

(53) Total inhibition. (54) Total inhibition in two trials. (55) Total inhibition.

(56) In $I \frac{I}{2}$ hours none germinated: in 3 hours several have tubes $I-3$ spore-diameters in

length. In 7 hours many have tubes 8 -Io spore-diameter. Same in watch-glass.

(57) Similar results, both in light and in darkness.

$(58,59)$ Vigorous germination in 2 hours.

(60) None germinated in 2 days.

(61) On thawing at $19^{\circ} \mathrm{C}$ none had germinated in 2 hours, but after $7 \frac{\mathrm{I}}{2}$ hours several spores had put out tubes, and next day the germination was fairly good and general.

(62) No recovery even in two days at $13-19^{\circ} \mathrm{C}$.

(63) Normal germination.

$(64,65)$ No germination. 


\section{Ward.-On Relations between Host and Parasite}

body in the cell-sap which inhibits or promotes the growth of the fungus; and I did so by making a cold-water extract of the pounded fresh leaves, rapidly filtering through a stone or other filter, and sowing the spores in the liquid both raw and boiled. In all cases control sowings were made in water, and only those results regarded where the controls showed the spores to be vigorous.

All attempts of this kind were in vain, however, since vigorous spores germinated equally well in extracts of the leaves of their own host-species and of their antagonistic hostspecies. See Table XI.

TABLE XI.

Expts. Nos. $739,781,782$, Testing the germination of spores in exiracls of the leaves of grasses.

\begin{tabular}{|c|c|c|c|c|c|}
\hline No. & Date. & Origin of spores. & State of spores. & Extract. & $\begin{array}{l}\text { Condition of } \\
\text { extract. }\end{array}$ \\
\hline $739^{a}$ & June 27 & B. mollis (1) & $\begin{array}{l}\text { Shed, from fresh } \\
\text { leaves I day }\end{array}$ & $\begin{array}{l}\text { Young leaves } \\
B \text { mollis }\end{array}$ & $\begin{array}{l}\text { Masson filter } \\
\text { not boiled }\end{array}$ \\
\hline$", b$ & " & " (2) & " & " & $\begin{array}{c}\text { Masson filter } \\
\text { boiled }\end{array}$ \\
\hline $\begin{array}{rr}\Rightarrow \quad c \\
781\end{array}$ & July 25 & B. mollis (4) & Kept I" day in & $\begin{array}{c}\text { Water only } \\
\text { " }\end{array}$ & \\
\hline$" b$ & $"$ & (5) & " & $\begin{array}{c}\text { Filtered extract of } \\
B \text { sterilis leaves }\end{array}$ & Un-boiled \\
\hline$\Rightarrow c$ & $"$ & ,.. (6) & " & , & Boiled \\
\hline $\begin{array}{l}782 a \\
, \quad b\end{array}$ & $"$ & $\begin{array}{c}\text { B. secalinus (7) } \\
, \quad(8)\end{array}$ & $"$, & $\begin{array}{l}\text { Water only } \\
\text { Extract of leaves }\end{array}$ & Un-boiled \\
\hline$\Rightarrow c$ & " &,$\quad(9)$ & " & $\begin{array}{c}\text { of } B . \text { sterilis } \\
, "\end{array}$ & Boiled \\
\hline
\end{tabular}

(1) One or two germinated.

$(3,4)$ Vigorous.

(7) Very vigorous.

(9) Equally vigorous.

(2) More than $10 \%$ germinated.

$(5,6)$ Germinated freely.

(8) Vigorous germination.

Of course these experiments teach very little, since it can hardly be supposed that the cell-contents thus extracted are in the normal condition in which they would exist in the living cell. The positive results do show, however, that the failure of spores from $B$. mollis (see below for details) to develop pustules on $B$. sterilis, for instance, is not due to a mere exudation of some antagonistic soluble extract, - that the 
antagonism must be due to something far more subtle than a mere soluble poison oozing from the cells.

\section{Methods of InfeCtion.}

The methods employed for the principal series of comparative infections were as follows.

The carefully selected 'seeds' of the Bromes were sown in new pots of fresh soil, generally a dozen to a score in a pot, and allowed to germinate under hand-glasses till about a week old. The pots were then placed under bell-jars, kept moist by filter-paper, and put in a west window in the laboratory for 24-48 hours, until the first green leaf (morphologically the second leaf) was well developed. During this period the 'spear,' enveloped in the first morphological leaf, which consists of the sheath only, exudes copious drops of water from the clefts corresponding to water-stomata at its apex.

In some cases I infected the seedlings by putting spores on these 'tip-drops': in others I placed the spores on the flat face of the leaf. It remains to be seen how far differences in results depend on these differences in procedure, as also whether anything depends on the different distribution of the stomata on the front and back of the leaf. The investigations of all these points in detail will require some time, but at present the evidence seems to show that it is immaterial, and that the infecting tubes can pass even into the slits representing water-stomata at the extreme tip.

In any case it is certain that the 'spears' are susceptible of infection when only two or three $\mathrm{mm}$. high, and long before the first green leaf is expanded, a point of some importance in discussing the question of the infectivity of seedlings.

In other cases I infected older seedlings at the base, apex, or intermediate parts of the second or third leaf, and one or two curious points arise in this connexion.

Infection may apparently fail at the base of rapidly growing young leaves, either because the stomata are not fully developed there, or because the rapidly elongating tissues pass forwards before the tips of the germ-tubes can gain an entrance. 
It is easy to see a tuft of paper-pulp, e. g., scraped filterpaper, with which spores have been swabbed up, and which has been placed in a young leaf-axil, lifted up bodily by the growth of the basal parts ; and next day, instead of the germtubes having entered the tissues of both young leaves with which the contaminated swab was in contact, the whole mass may have been lifted up on one leaf, or thrown off bodily on to the ground.

If such a 'swab' is placed on the apex of the growing leaf, on the contrary, it is lifted up as the tip rises and infection occurs. This ready infection of the tips, the oldest part of the grass leaf, seems to explain why pustules ordinarily appear first at the apex of the leaves. The latter are most easily infected there because the 'tip-drops,' emerging from the water-stomata under the action of root-pressure, catch spores readily, and promote their germination just on that part of the leaf where the stomata are most mature; and this would apply particularly to wind-blown spores which lodge in or near the leafaxils in the tufts of grass.

In sowing the Uredospores I have tried various plans. The simplest is to place the dry spores direct from the pustules on the surface of the leaf by means of the tip of the blade of a knife or a flattened platinum wire. Another is to brush them on with a camel-hair pencil. They may also be sown in water, and a drop of the latter then placed on the leaf by a fine pipette or a wire, \&c., but some difficulty is usually met with owing to the tendency of such drops to roll off the slightly waxy or hairy leaf-surface. I found it at first by no means easy to attach such drops to the leaf-surface, especially as the latter is usually vertical.

An interesting proof that this is owing to the difficulty of wetting the leaf is afforded by the following observation. If one takes a slender capillary pipette and blows down it so as to direct the fine stream of moisture-laden air on to a spot on the leaf-surface, the latter will readily take the drop at that spot and hold it. I take it this is owing to the fact that moisture has condensed on the cuticle in extremely fine 
particles, which then run together, and the drop may then be held by capillary attraction to the now wetted surface.

A method which promised to obviate some of the drawbacks referred to was that of placing minute swabs of cottonwool or paper-pulp-scraped filter-paper fibres-saturated with spore-laden water on the leaves; such swabs stick well and as they dry mark the spot infected: but although their presence does not hinder the germination of the spores, the method was not particularly successful, for in some cases the germ-tubes ran into the damp interspaces of the cottonwool and there lost themselves, as it were.

Returning now to the treatment of the seedlings. Having sown the spores, each pot was covered with a large inverted beaker lined with moist filter-paper, and placed in the west window. After 24-48 hours the beakers were removed, and the pots placed under very large bell-jars in zinc trays, and these bell-jars were usually removed on the third or fourth day, and the pots placed in the open.

Of course differences in detail of procedure had to be introduced to meet exigencies of weather, and I availed myself of the cellar or area in the hottest weather, and of tables and boxes in shade and half-shade in various positions in the garden. These details are given in the tabulated results.

It is certain that these differences of temperature, illumination, drought and wet, and so forth, affecting the transpiration, assimilation, \&c., of the seedlings, also affect the period of germination, inoculation, and incubation, and difficulties in explaining various phases can be overcome only when this is understood.

\section{The Results of Infection.}

Successful inoculation is followed by a period of incubation usually about a week to ten days in duration, during which period the hyphae are spreading in the intercellular spaces.

We have seen that the germination of the spore is ruled by certain factors of which temperature is very important, 


\section{Ward.-On Relations between Host and Parasite}

perhaps the most important -it being always understood that sufficient moisture is present.

The effects to be looked for, about the tenth day, on those parts of the leaves on which Uredospores have been sown, are outbreaks of the well-known sienna-brown or orangebrown tufts of Uredospores similar to those sown. These appear first as minute yellow pimples or pustules, pushing up the epidermis and then bursting through as they rupture it at the stomata. The outbreak of such pustules is the proof of successful infection.

Preceding the actual outbreak of pustules, often by several days, we have a pale yellowish discoloration of the leaf, at the spot infected, and it not unfrequently happens that such pale flecks are alone formed, and never advance so far as to develop spores. Sections of these infection-flecks show the presence of the mycelium in the tissues, and the loss of colour is due to two causes-the destruction of chlorophyll in the attacked cells, and the filling up of the intercellular spaces by the hyphae, thus rendering the mass more translucent than when filled with air.

In yet other cases I find an active discoloration of another kind produced at the infected spots. The tissues turn yellow and then brown or black, rapidly shrivelling as if corroded. This is due to the actual death of the cells and withering of the tissues at the infected spots, and at first I thought it must be owing to some other fungus having got in. It is so in some cases, but in the majority of those to be considered it appears to be due, rather, to the infecting tubes and hyphae being too destructive to adapt themselves to the host-tissues, and must be regarded as a sign of failure of infection, because the Uredo-mycelium is unable to advance in the dead area, and of course no pustules are developed. We might compare the unsuccessful mycelium here to a pot-plant placed in unsuitable soil, and therefore incapable of flowering.

It will thus be intelligible that four cases may occur as the incubation period runs its course. At the one extreme we may find no visible effect at all : the spores have either not 
germinated on the epidermis, or the infection has failed, owing to the germ-tubes being unable to enter the stomata and establish a mycelium in the intercellular spaces.

At the other extreme we have successful entry and infection, and the mycelium in the leaf gives rise to the pustules of Uredospores in due course.

Thirdly, we may have the intermediate stage where pale flecks betray the presence of a mycelium in the intercellular spaces, but circumstances prevent this coming to maturity as a spore-producing organism, and so no pustules of Uredospores are formed.

Whether this internal mycelium ${ }^{1}$ eventually lives or dies depends on several factors; the point here is that it remains barren of spores.

The fourth case is met with when the tissues turn brown and die, the destructive action of the infecting tubes having killed the cells too rapidly. The affected patch thus appears corroded, and since the dead cells are unsuitable as a medium for further growth of the mycelium, the parasite dies.

In the following tables I record the infection as successful or positive (indicated by the sign + ) only when the sporebearing pustules are developed at the infected spots. In all other cases it is unsuccessful or negative (indicated by the signs $\mathrm{O}$ or -) and only when necessary is the remark added that the infected spots show 'flecks' or 'corrosion' respectively. The histological details and figures are held over for the present, with other continuations of the work, and will form the subject of further communication.

\section{Experiments with Pot-Plants.}

The first set of experiments of which I propose to give the results here, was simply planned to see whether seedling plants, of manageable size and in small pots, were suitable for the purposes of the investigation. The procedure adapted was as follows.

Seedling plants of the species of Bromus referred to below

1 Internal, that is to the leaf as a whole, but really in the intercellular spaces. 
were removed from their seed-beds in the Gardens, after having been weeded out and exposed for several weeks, and were potted off into small pots of soil, with no extraordinary precautions. Each plant had three to five leaves, and the infection was carried out by simply placing spores on the lamina and marking the leaf with silk.

The results seemed to show that spores taken from leaves of $B$. mollis, infected $B$. mollis and $B$. secalinus freely, but refused to infect $B$. inermis, while the results were doubtful as regards $B$. sterilis, $B$. asper, and $B$. arvensis.

Repetition of the experiment gave similar results, except that here the infection sometimes failed on $B$. mollis; and yet again a third experiment yielded similar results, except that this time it was $B$. sterilis which gave the doubtful result.

It eventually suggested itself as possible that more care was necessary in keeping the spores taken from the leaves of $B$. mollis and those from the leaves of $B$. sterilis separate, for although I only employed those from $B$. mollis for the infections, I had collected both in the same tin though separated in paper wrappings, and did not at the time regard it as of such supreme importance as was subsequently found to be the case to keep them separate. It being admitted that the fungus is the same on both species this was not unnatural, at the time, but the sequel showed that all such assumptions must be avoided where these fungi are concerned. Although it is the species Puccinia dispersa, whether growing on Bromus mollis or $B$. sterilis, I now know that the infection capacity differs much in the two cases.

In this, the first set of experiments in which my attention was directed to the question of adaptation or selective infection within the genus Bromus itself, several sources of error are to be met with, the most serious being one to which sufficient attention has not always been paid in the past, though most careful observers must have thought of it. It depends on the recognition of the fact that Uredospores when capable of normal germination at all, are highly infectious spores, and that if the host-plants used are-as is usually the case-ex- 
posed in a garden or even in a greenhouse or laboratory already contaminated with such spores, the same kinds of difficulties and dangers may arise as in any other work where highly contaminating organisms have access to the experi$\mathrm{m} \sim$ nts.

On putting together the total results of these preliminary infections of garden seedlings, removed from the beds to pots and then infected, we get the following:-

In no case apparently did the spores taken from the leaves of $B$. mollis infect $B$. inermis, and in no case did they fail to infect $B$. secalimus, and with a few doubtful exceptions $B$. mollis.

As regards $B$. asper, $B$. arvensis, and $B$. sterilis the results were less consistent.

Similarly with the spores from $B$. sterilis. They failed to infect $B$. mollis, $B$. arvensis, and $B$. inermis in all cases: they infected B. asper and B. secalimus, however, in the only case tried.

On looking more carefully into these preliminary trials, I found that several sources of error needed careful examination. In the first place, the seedlings themselves had been growing for some time in the open, and there was no guarantee that their leaves were free from wind-borne spores at the time of transplanting. As matter of fact, on searching the tufts of seedlings in the garden during the next two or three weeks I found the Uredo on $B$. asper, $B$. secalinus, $B$. mollis, and $B$. sterilis, and subsequently on others.

Secondly, I had collected both $B$. mollis and $B$. sterilis, with spores on them, from the same fields, and, as already stated, was not at the time fully alive to the existence of any physiological difference between the two forms: morphologically the two forms are identical. It is true I kept the two kinds separate in my collecting tins, but considering the quantity of spores already forming on $B$. mollis in the fields, it would not be surprising if the leaves of $B$. sterilis had already been dusted with them.

Thirdly, it soon appeared certain that an experimental error had crept in in the case of at least one of the experiments. 
But the most irritating error of all, and one which caused much trouble in the immediate future, was the discoveryonly made after the plants had come into flower-that the seedlings labelled $B$. asper were not $B$. asper at all, but $B$. arvensis - that is to say an error had been made by the seedsman who supplied the seed. In consequence of this, I had to overhaul the whole stock of seeds and seedlings myself, and in the experiments which follow believe there need be no doubt as to the authenticity of the species, except in one or two special cases to which attention will be drawn where necessary; and in regard to which further investigations are proceeding.

It becomes clear, in fact, that we have to keep our eyes open to the danger of impure cultures of the hosts, as well as of the parasite. As will be seen in the sequel, we have also to take account of variations and race-peculiarities in both.

Considering these and other possibilities of error, I was led to devise some better methods of preparation and infection of the culture-plants and spores.

In the following experiment (see Table XII) sowings in pots were made of eleven carefully selected species or varieties of Bromus, viz.: B. mollis, L., B. secalinus, L., B. velutinus, Schrad., B. maximus, Desf., B. arvensis, L., B. racemosus, L., B. commutatus, Schrad., B. intermptus, Hack., B. sterilis, L., $B$. madritensis, L., $B$. erectus, Huds. Good garden soil was used, and germination, under a hand-glass in the garden, resulted normally during the warm weather, so that in a week it was possible to start the infections. It may be noted, however, that whereas $B$. mollis showed above ground on the fourth day, and $B$. arvensis and $B$. maximus were up by the fifth day after sowing, it required six days for $B$. sterilis, $B$. madritensis, and $B$. secalinus, and seven days for $B$. racemosus and $B$. interruptus to be sufficiently high, while $B$. commutatus and $B$. erectus were not well up ${ }^{1}$ until the eighth day.

The infections were made by placing Uredospores from

2 I regarded the seedlings as 'well up' when I-3 mm. showed above ground. 
$B$. mollis and $B$. sterilis gathered on June $\mathrm{I}$, from widely distant localities and kept in separate tin boxes till June 3, on the drops of water hanging from the water-pores at the tips of the first leaves. This method is quite successful in such cases, as direct and repeated observations have shown: the germ-tubes soon make their way to the stomata of the emerging leaf, and infection results near the apex only.

Three pots of each species (or variety) were sown. One of each was infected with Uredospores from B. mollis, another with those from $B$. sterilis, while the third series was not infected, but kept as a control set. Each series was kept under a large bell-jar, with damp filter-paper in it, and left thus covered at a western window for two days. After that the whole of the series was put outside, in a sheltered spot, but still covered with the bell-jars. The garden used was well away from any plants of Bromus, and no diseased plants were allowed in it except such as I brought there. At the end of a week they were fully exposed to the weather. The latter had been warm and sunny during the first week, but by June $\mathrm{I}_{2}-\mathrm{I} 3$ it turned cold and some rain fell, and several days of dull or wet weather, often very cold, followed, varying as to wind which was sometimes bleak and dry. The principal assumptions entertained here were: (I) that carefully selected clean 'seeds,' germinated in new pots under glass at a distance from any known source of infection, would give me host-plants free from contamination ; (2) that by gathering the spore-material from places some distance apart, and keeping it in each case quite separate in closed boxes, tubes, \&c., it should be possible to ensure freedom from accidental infection; (3) that by keeping the inoculated plants under glass until infection was well assured, it should be possible to avoid accidental infection; because, even assuming that wind-blown spores reached the plants after subsequent exposure, the resulting pustules would appear so late that I could discriminate between the consequences of the primary and of the secondary infection; (4) there was the further assumption that the artificially induced infection would occur 
normally in the tips of the young leaves just emerging from the first leaf-sheath, although the seedlings were of different heights at the moment of inoculation.

Further experience has shown that these assumptions, carefully checked, do not vitiate the conclusions drawn from the experiments.

There was, nevertheless, a possible source of error in the large number of plants employed in these experiments. Each pot contained from 25 to 100 seedlings, according to the size of the 'seeds' sown and their germinating power. I inoculated about ten to twenty seedlings in each case, and judged of the results as merely positive or negative according to the subsequent discovery of pustules. I now know that it may be of some importance whether the plants are well or ill-nourished, and it is quite possible that in some of the more crowded pots the results were less convincing than in later experiments whence this source of error was eliminated. Nevertheless such plants show normal infection.

The question as to the height of the 'spear' above ground need not concern us, since subsequent experiments, where the heights were duly measured and recorded, showed that a given species will be infected readily when only $10-20 \mathrm{~mm}$. high, whereas the infection fails on another $50-100 \mathrm{~mm}$. high.

The results are given in the following Table XII.

These results point to the conclusion that while the Uredo grown on $B$. mollis can quickly and readily infect $B$. mollis, $B$. velutinus, $B$. arvensis, $B$. secalinus, and $B$. racemosus-all, be it remarked, closely allied forms-it is unable to infect $B$. sterilis, $B$. madritensis, $B$. maximus, $B$. erectus, B. commutatus, or $B$. interruptus, or does so with difficulty.

On the other hand, while the Uredo grown on B. sterilis can readily infect $B$. sterilis and $B$. madritensis-also closely allied-it appears to fail on the other Bromes, except possibly on $B$. maximus.

In all cases the control series gave negative results.

As the Table XIII (p. 284) shows, substantially similar results were obtained on repeating this experiment on seed- 


\section{TABLE XII.}

Exp. No. 706, June 4, r9or. 'Seed' sown May 27. Bromes infected on tips of seedlings just $(2-15 \mathrm{~mm}$.) above ground, germinated under hand-glass in garden. Infected plants put outside, under bell-jars, after $48 \mathrm{~h}$., in N. light, then (after a week) exposed. Get sun about 2 hours at mid-day. Normal plants, though small.

\begin{tabular}{|c|c|c|c|c|c|c|c|}
\hline Species. & $\begin{array}{l}\text { Origin of } \\
\text { spores. }\end{array}$ & Results. & $\begin{array}{l}\text { Approximate } \\
\text { No. of plants } \\
\text { infected. }\end{array}$ & $\begin{array}{r}\text { Incubc } \\
\text { peric }\end{array}$ & $\begin{array}{l}\text { ation } \\
\text { od. }\end{array}$ & $\begin{array}{l}\text { No. of leaves } \\
\text { with pustules } \\
\text { on I } 9 \text { th day. }\end{array}$ & $\begin{array}{l}\text { Period of } \\
\text { observation. }\end{array}$ \\
\hline 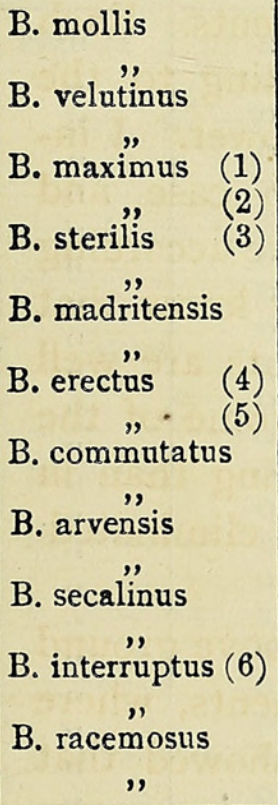 & $\begin{array}{l}\text { B. mollis } \\
\text { B. sterilis } \\
\text { B. mollis } \\
\text { B. sterilis } \\
\text { B. mollis } \\
\text { B. sterilis } \\
\text { B. mollis } \\
\text { B. sterilis } \\
\text { B. mollis } \\
\text { B. sterilis } \\
\text { B. mollis } \\
\text { B. sterilis } \\
\text { B. mollis } \\
\text { B. sterilis } \\
\text { B. mollis } \\
\text { B. sterilis } \\
\text { B. mollis } \\
\text { B. sterilis } \\
\text { B. mollis } \\
\text { B. sterilis } \\
\text { B. mollis } \\
\text { B. sterilis }\end{array}$ & $\begin{array}{rr}+ & \\
+ & - \\
& - \\
& + \\
+ & + \\
+ & - \\
+ & + \\
& - \\
& - \\
+ & - \\
+ & - \\
& + \\
+ & -\end{array}$ & $\begin{array}{l}20 \\
20 \\
20 \\
20 \\
? * \\
? \\
? \\
? \\
20 \\
15 \\
10 \\
10 \\
20 \\
20 \\
12 \\
12 \\
8 \\
15 \\
20 \\
20 \\
10 \\
10\end{array}$ & $\begin{array}{l}\text { I9 } \\
\text { I9 } \\
\text { 19 } \\
\text { 10 } \\
\text { 10 } \\
\text { I9 }\end{array}$ & $\begin{array}{l}" \\
" \\
" \\
",\end{array}$ & $\begin{array}{r}10 \\
0 \\
19 \\
0 \\
1 \\
1 \\
3 \\
18 \\
0 \\
14 \\
1 \\
0 \\
0 \\
0 \\
10 \\
0 \\
6 \\
0 \\
2 \\
0 \\
6 \\
0\end{array}$ & $\begin{array}{c}2 \text { I days } \\
\text { ", } \\
\text { " } \\
" \\
" \\
" \\
" \\
" \\
" \\
" \\
" \\
" \\
" \\
" \\
" \\
" \\
"\end{array}$ \\
\hline
\end{tabular}

(1-3) Must be regarded as doubtful ?

(4) Must be regarded as doubtful ?

(6) Must be regarded as doubtful?

(5) 10 infected.

* About 20, but not exactly recorded.

lings slightly forced in the intermediate pit, and kept during incubation in a damp shady corner where they never got direct sunlight at all. The plants were much drawn, slightly pale in colour, and very succulent-i.e. they were more or less slightly etiolated. The principal differences were the very poor pustules developed and fewer positive results. In some cases-e.g., B. arvensis and B. secalinus-the period of incubation seemed to be lengthened, while in others no comparison seems possible.

As the Table XIII shows, the spores of $B$. mollis infected $B$. mollis readily and $B$. arvensis and $B$. secalinus more slowly, but they did not successfully attack $B$. velutinus and $B$. race- 
TABLE XIII.

Exp. No. 707, June 8, 1901. 'Seed' sown June r. Seedlings germinated in intermediate pit one week, then infected at tips and kept under glass 48 hours. Then outside under glass, in damp shady corner. Very damp and drawn plants.

\begin{tabular}{|c|c|c|c|c|c|c|c|}
\hline Species. & $\begin{array}{l}\text { Origin of } \\
\text { spores. }\end{array}$ & Results. & $\begin{array}{l}\text { Approximate } \\
\text { No. of seed- } \\
\text { lings infected. }\end{array}$ & \multicolumn{2}{|c|}{$\begin{array}{l}\text { Incubation } \\
\text { period. }\end{array}$} & $\begin{array}{l}\text { No. of leaves } \\
\text { with pustules } \\
\text { on I6th day. }\end{array}$ & $\begin{array}{c}\text { Period of } \\
\text { observation. }\end{array}$ \\
\hline $\begin{array}{l}\text { B. mollis (1) } \\
\text { B. velutinus } \\
\text { B. maximus } \\
\text { B. sterilis (2) } \\
\text { B. madritensis } \\
\text { B. erectus } \\
\text { B. commutatus } \\
\text { B. arvensis } \\
\text { B. secal"̈us } \\
\text { B. interruptus } \\
\text { B. racemosus } \\
\text { ", }\end{array}$ & $\begin{array}{l}\text { B. mollis } \\
\text { B. sterilis } \\
\text { B. mollis } \\
\text { B. sterilis } \\
\text { B. mollis } \\
\text { B. sterilis } \\
\text { B. mollis } \\
\text { B. sterilis } \\
\text { B. mollis } \\
\text { B. sterilis } \\
\text { B. mollis } \\
\text { B. sterilis } \\
\text { B. mollis } \\
\text { B. sterilis } \\
\text { B. mollis } \\
\text { B. sterilis } \\
\text { B. mollis } \\
\text { B. sterilis } \\
\text { B. mollis } \\
\text { B. sterilis } \\
\text { B. mollis } \\
\text { B. sterilis }\end{array}$ & $\begin{array}{r}+ \\
\overline{-} \\
\bar{z} \\
+ \\
+ \\
+\quad \\
- \\
- \\
\overline{-} \\
+ \\
+ \\
- \\
- \\
-\end{array}$ & $\begin{array}{r}20 \\
20 \\
20 \\
20 \\
20 \\
20 \\
20 \\
20 \\
20 \\
20 \\
10 \\
10 \\
20 \\
20 \\
12 \\
12 \\
8 \\
10 \\
20 \\
20 \\
10 \\
10\end{array}$ & $\begin{array}{l}10 \\
10\end{array}$ & ys & $\begin{array}{r}2 \\
0 \\
0 \\
0 \\
0 \\
1 \\
0 \\
10 \\
0 \\
3 \\
0 \\
0 \\
0 \\
0 \\
2 \\
0 \\
2 \\
0 \\
0 \\
0 \\
0 \\
0\end{array}$ & $\begin{array}{c}2 \text { I days } \\
\text { ", } \\
\text { " } \\
" \\
" \\
" \\
" \\
" \\
" \\
" \\
" \\
" \\
" \\
" \\
" \\
" \\
"\end{array}$ \\
\hline
\end{tabular}

(1) I I other leaves have spots not burst, owing to drying up of tips.

(2) Perhaps doubtful?

mosus as they did in the previous experiment. As before, $B$. sterilis, $B$. madritensis, $B$. maximus, B. erectus, B. commutatus, and $B$. interruptus seemed to resist the fungus.

Again, we see that the spores from $B$. sterilis readily infect in $B$. sterilis and $B$. madritensis, but not others, except in the doubtful case of $B$. maximus.

This series undoubtedly raises questions as to how far the physiological condition of the host affects the question of infection, a question to which I shall return subsequently.

In another series, Table XIV, the seedlings were raised as in the previous series, and the infected plants were kept in the laboratory at a west window under damp bell-jars. Thus the general temperature was considerably higher than 
before, and bright sunlight reached the plants for several hours during the afternoon. On the whole, this seemed to shorten the incubation period and to enhance the number and rapidity of the infections. The plants were somewhat drawn, owing to the damp close atmosphere, but the pustules developed were larger and more numerous than in the last series.

From this Table XIV may be gathered confirmation of

\section{TABLE XIV.}

Exp. No. 708, June 10, I901. 'Seed' sown June 3. Seedlings germinated in open under hand-glass, and infected when one week old, and just above ground $(2-5 \mathrm{~mm}$.). The infected plants kept in laboratory, under glass, in W. window. Plants damp and somewhat drawn.

\begin{tabular}{|c|c|c|c|c|c|c|c|}
\hline Species. & $\begin{array}{l}\text { Origin of } \\
\text { spores. }\end{array}$ & Results. & $\begin{array}{l}\text { Approximate } \\
\text { No. infected. }\end{array}$ & $\begin{array}{r}\text { Incub } \\
\text { peri }\end{array}$ & $\begin{array}{l}\text { ation } \\
\text { od. }\end{array}$ & $\begin{array}{l}\text { No. of leaves } \\
\text { with pustules } \\
\text { on I 4th day. }\end{array}$ & $\begin{array}{c}\text { Period of } \\
\text { observation. }\end{array}$ \\
\hline $\begin{array}{l}\text { B. mollis } \\
\text { B. velutinus } \\
\text { B. maximus } \\
\text { B. sterilis } \\
\text { B. madritensis } \\
\text { B. erectus } \\
\text { B. commutatus } \\
\text { B. arvensis } \\
\text { B. secal", } \\
\text { B. interruptus } \\
\text { B. racemosus } \\
\text { ", }\end{array}$ & $\begin{array}{l}\text { B. mollis } \\
\text { B. sterilis } \\
\text { B. mollis } \\
\text { B. sterilis } \\
\text { B. mollis } \\
\text { B. sterilis } \\
\text { B. mollis } \\
\text { B. sterilis } \\
\text { B. mollis } \\
\text { B. sterilis } \\
\text { B. mollis } \\
\text { B. sterilis } \\
\text { B. mollis } \\
\text { B. sterilis } \\
\text { B. mollis } \\
\text { B. sterilis } \\
\text { B. mollis } \\
\text { B. sterilis } \\
\text { B. mollis } \\
\text { B. sterilis } \\
\text { B. mollis } \\
\text { B. sterilis }\end{array}$ & $\begin{array}{r}+ \\
+ \\
- \\
- \\
- \\
- \\
+\quad- \\
+\quad \\
- \\
+ \\
+ \\
+ \\
+ \\
+ \\
+ \\
+\end{array}$ & $\begin{array}{r}20 \\
20 \\
20 \\
20 \\
20 \\
20 \\
20 \\
20 \\
20 \\
20 \\
10 \\
10 \\
20 \\
20 \\
10 \\
10 \\
8 \\
8 \\
20 \\
20 \\
10 \\
10\end{array}$ & $\begin{array}{l}\text { I } 2 \\
9 \\
\text { I5 } \\
\text { I0 }\end{array}$ & $\begin{array}{l}\text { " } \\
\text { ", }\end{array}$ & $\begin{array}{r}16 \\
0 \\
\text { I } \\
0 \\
0 \\
0 \\
0 \\
\text { I } 9 \\
0 \\
\text { I6 } \\
0 \\
0 \\
5 \\
0 \\
8 \\
0 \\
3 \\
0 \\
7 \\
0 \\
3 \\
0\end{array}$ & $\begin{array}{c}2 \text { I days } \\
\text { ", } \\
\text { ", } \\
\text { ", } \\
\text { ", } \\
\text { ", } \\
\text { ", } \\
\text { ", } \\
\text { ", } \\
\text { ", } \\
\text { ", }\end{array}$ \\
\hline
\end{tabular}

the readiness with which spores from $B$. mollis infect that species and $B$. arvensis and $B$. velutinus; $B$. secalinus and $B$. racemosus being also successfully attacked, as are, moreover, $B$. interruptus and $B$. commutatus, all closely allied species, be it noted. B. sterilis, B. madritensis, B. maximus, and B. erectus, on the other hand seem immune, as in previous cases.

Here, too, spores from $B$. sterilis readily infected only that 


\section{Ward.-On Relations between Host and Parasite}

species and $B$. madritensis but not the others; results quite in accordance with previous experience.

If now we summarize the results of the infections in these three series-remembering that the method of infection and. age of the plants used was the same in all, the only differences being in the dates of sowing and the after-treatment of the plants-some suggestive facts come to light, as the following Table XV shows.

TABLE XV.

Summary of Exp. Nos. 706-8.

\begin{tabular}{|c|c|c|c|c|c|c|}
\hline Species. & $\begin{array}{l}\text { Origin of } \\
\text { spores. }\end{array}$ & & & & $\begin{array}{l}\text { Incubation } \\
\text { period. }\end{array}$ & $\begin{array}{c}\text { No. of infected } \\
\text { plants showing } \\
\text { pustules. }\end{array}$ \\
\hline B. mollis & B. mollis & + & + & + & 9-II days & 28 \\
\hline & B. sterilis & - & - & - & & $\circ$ \\
\hline B. velutinus & B. mollis & + & - & + & II I I & 20 \\
\hline B. maximus (1) & B. sterilis & $\bar{t}$ & $\overline{-}$ & $\overline{-}$ & 10 & $\begin{array}{l}0 \\
\text { I }\end{array}$ \\
\hline " (2) & B. sterilis & + & + & - & 13-19" & 2 \\
\hline B. sterilis & B. mollis & + & - & - & I9 " & 3 \\
\hline 1 & B. sterilis & + & + & + & $8-10 "$ & 47 \\
\hline B. madritensis & B. mollis & - & - & - & & $\circ$ \\
\hline B erectus (4) & B. sterilis & + & + & + & $9^{-10} "$ & 33 \\
\hline B. erectus & B. mollis & \pm & - & - & $19 "$ & $\begin{array}{l}\text { I } \\
0\end{array}$ \\
\hline B. commutatus & $\begin{array}{l}\text { B. sterillis } \\
\text { B. mollis }\end{array}$ & - & - & + & $12 "$ & 5 \\
\hline B. arvensis & $\begin{array}{l}\text { B. sterilis } \\
\text { B. mollis }\end{array}$ & $\bar{t}$ & $\bar{x}$ & - & & 0 \\
\hline B. arven & $\begin{array}{l}\text { B. mollis } \\
\text { B. sterilis }\end{array}$ & \pm & $\stackrel{+}{-}$ & \pm & $9^{-10} \quad "$ & $\begin{array}{r}20 \\
0\end{array}$ \\
\hline B. secalinus & B. mollis & + & + & + & II-I $6, "$ & II \\
\hline & B. sterilis & - & - & - & & ० \\
\hline B. interruptus (5) & B. mollis & $x$ & - & + & $10-19 "$ & 9 \\
\hline B. racemosus & $\begin{array}{l}\text { B. sterilis } \\
\text { B. mollis }\end{array}$ & $\bar{t}$ & $\overline{-}$ & $\overline{+}$ & I I-I $2, "$, & 9 \\
\hline$"$ & B. sterilis & - & - & - & & 0 \\
\hline
\end{tabular}

(1-5) Doubtful as to the positive result?

The three experiments leave little room for doubt that under circumstances in which $B$. mollis is rapidly and easily infected by the spores from $B$. mollis (the incubation period being nine to eleven days), $B$. sterilis is either immune or only with difficulty and slowly infected by this fungus-e.g., after nineteen days in three cases out of about twenty (see Table XII). 
The spores from $B$. mollis also infect $B$. arvensis readily, and $B$. secalinus, $B$. interruptus, $B$. racemosus, and $B$. velutinus less readily.

On the other hand, while the spores of $B$. sterilis rapidly and easily infect that species (incubation period ten days), they are unable to successfully attack $B$. mollis even after twenty-one days.

Now this, put in other words, seems to mean that the spores of the brown Uredo $(P$. dispersa) if grown on $B$. mollis are able to infect successfully practically any member of the group Serrafalcus, and but rarely or not at all any member of the other sections so far examined of the genus Bromus; whereas the same fungus grown on $B$. sterilis readily infects members of its own group Stenobromus-e.g., B. sterilis, $B$. madritensis, and $B$. maximus-but is debarred from the Serrafalcus group.

The matter appeared so important that I proceeded to try to get results even more conclusive and free from possible sources of error.

I here add the results given in Table XVI, though they teach nothing new except to show the kind of error which may creep into such experiments, in the case of the one plant of $B$. erectus which appeared to have been successfully infected by spores from $B$. mollis, which it was practically certain was not the case.

The procedure adopted in the next series of experiments was to start the germination in new pots under glass in the garden ${ }^{1}$, as before, but to allow only a small definite number of plants to each pot. When old enough to infect-i.e. when at least one leaf was completely formed and expanded -I infected a certain definite proportion of the seedlings at known spots on marked leaves, and recorded the results. The uninfected seedlings thus served as controls. In most cases also I carefully tested the germinating power of the spores used in two ways: in cells and in open watch-glasses,

1 It has been already stated that there were no Bromes or Brome Rust in the garden here referred to, except such as I had under experimental control. 


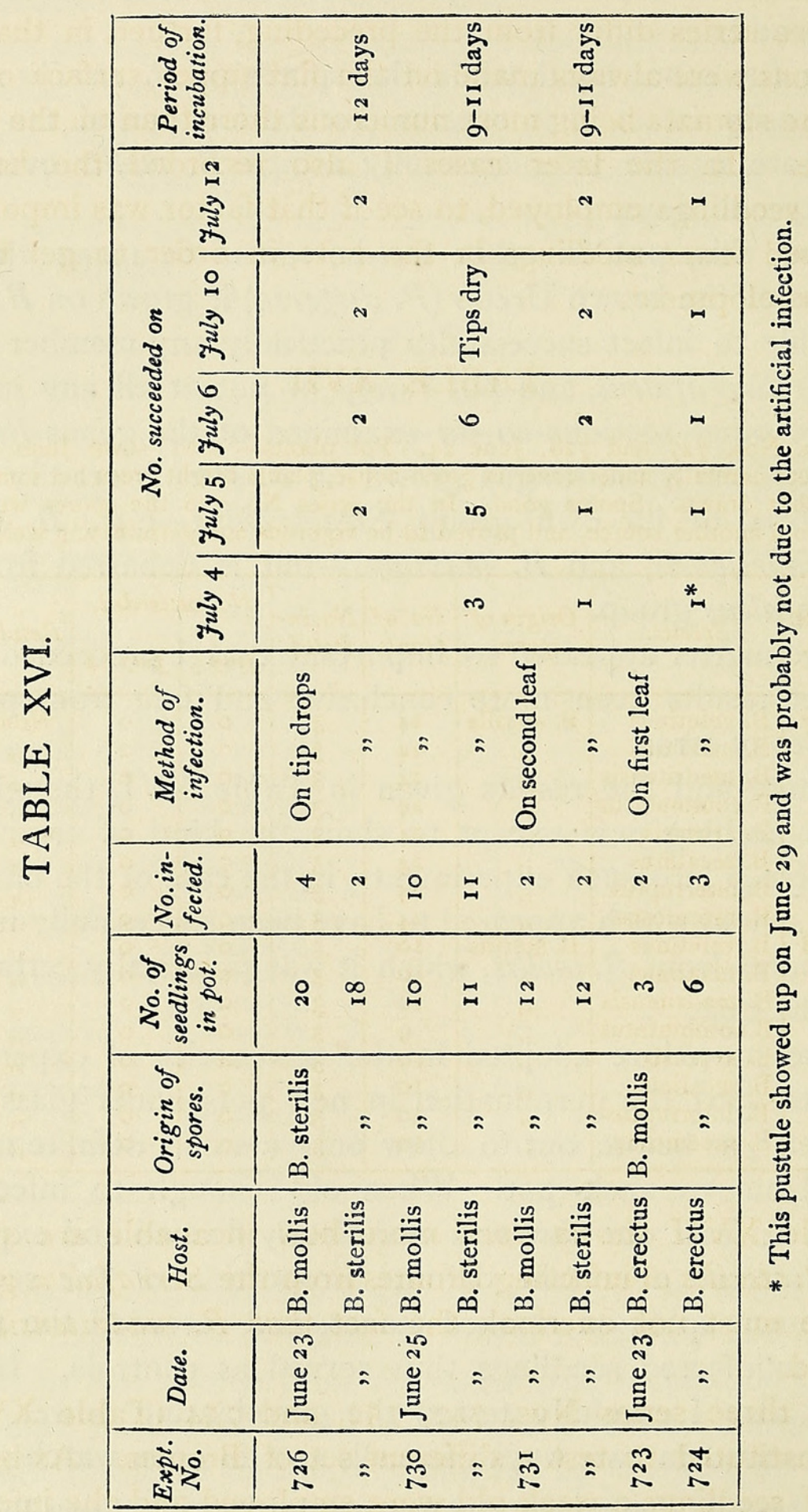


and employed all care in the selection of mature spores from unexhausted leaves.

These series differ from the preceding, further, in that the infections were always made on the flat upper surface of the leaf, the stomata being more numerous there than on the lower surface. In the later cases I also recorded the heights of the seedlings employed, to see if that factor was important, and used fewer seedlings in the pots, in order to get better root-development.

\section{TABLE XVII.}

Exp. Nos. 727 and 728, June 24. Pot plants-'seed' sown June Io kept carefully under cover in green-house, plants bright green but somewhat drawn. Spores good. In the series No. 728 the spores were from another source, and proved to be vigorous and germinating well.

\begin{tabular}{|c|c|c|c|c|c|c|c|}
\hline $\begin{array}{l}\text { Expt. } \\
\text { No. }\end{array}$ & Species. & $\begin{array}{c}\text { Origin of } \\
\text { spores. }\end{array}$ & $\begin{array}{l}\text { No. of } \\
\text { plants. }\end{array}$ & $\begin{array}{l}\text { No. in- } \\
\text { fected. }\end{array}$ & $\begin{array}{l}\text { No. su } \\
\text { Fuly } 5\end{array}$ & $\begin{array}{l}\text { cceeded. } \\
\text { fuly I } 2\end{array}$ & Results. \\
\hline 727 & B. velutinus & B. sterilis & 24 & 3 & 0 & 0 & None \\
\hline , & B. maximus & , & 24 & 3 & 0 & 0 & , \\
\hline 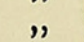 & B. madritensis &, & 24 & 3 & 0 & 0 & " \\
\hline " & B. commutatus & , & 24 & 3 & 0 & 0 & $"$ \\
\hline$"$ & B. arvensis & , & 24 & 3 & 0 & 0 & 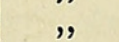 \\
\hline , & B. secalinus & 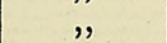 & 24 & 3 & o & 0 & , \\
\hline ", & B. interruptus & , & 24 & 3 & 0 & 0 & $”$ \\
\hline " & B. racemosus & & 24 & 3 & 0 & $\circ$ & " \\
\hline 728 & B. velutinus & B. sterilis & IO & 3 & 0 & 0 & , \\
\hline " & B. maximus & ," & IO & 3 & 0 & o & , \\
\hline$"$ & B. madritensis & , & IO & 3 & 0 & 0 & , \\
\hline , & B. commutatus & , & 9 & 3 & o & 0 & 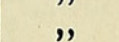 \\
\hline , & B. arvensis & , & Io & 3 & 0 & 0 & , \\
\hline " & B. secalinus & , & I0 & 3 & 0 & o & , \\
\hline " & B. interruptus & $"$ & IO & 3 & o & 0 & , \\
\hline ", & B. racemosus & , & IO & 3 & 0 & 0 & , \\
\hline
\end{tabular}

Table XVII shows once more how incapable are spores from $B$. sterilis of infecting Bromes from the Serrafalcus group, but we must not overlook the fact that $B$. madritensis also escaped.

The three series Nos. $747,75^{2}$, and 754 (Table XVIII) were instituted to test a different set of Bromes. As before, pots of seedlings a week old were employed and the infection was at the tips of the spears, the spores being laid on in wet 


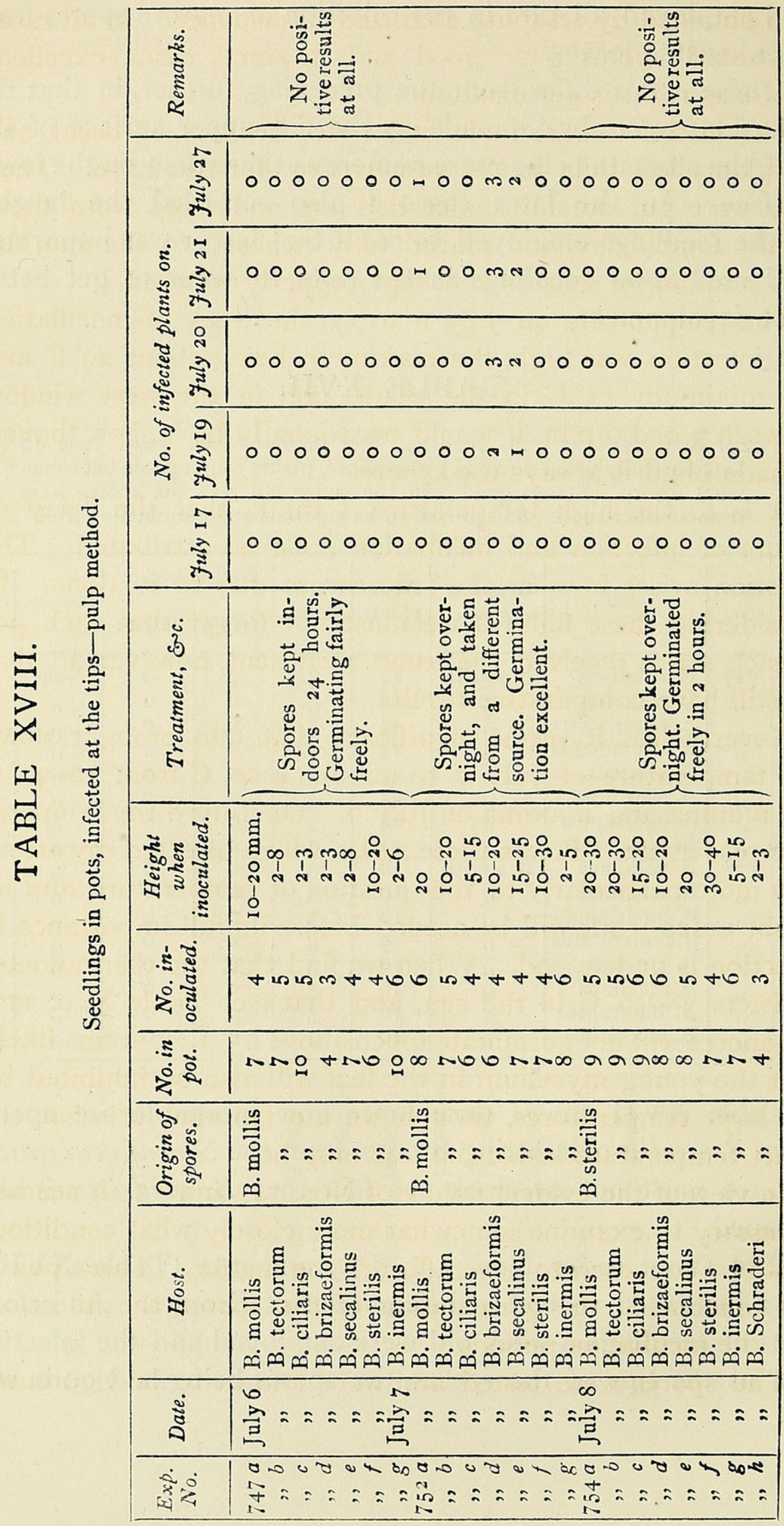


pulp obtained by scraping sterilized filter-paper. In all cases the tested spores gave good and in some cases excellent results as regards germination.

The infection was made under wet beakers, as usual, and the plants left thus at the west window for two days. Then they were put outside under bell-jars, and freed from these on the fourth day, and placed fully exposed to the sun, the pots standing in saucers and kept properly watered.

The temperature on July 6 to I 3 , the week of inoculation and infection, was high, the maximum being about $29^{\circ} \mathrm{C}$ and the minimum $15^{\circ} \mathrm{C}$ in the shade, and in the west window between 3 and 6 p.m. it would occasionally be higher, though a shade blind is always used there.

It is to the high temperature, I think, that the delay or failure of infection and incubation must be attributed. The question arises how far the failures are due to it alone. In considering these failures we must not forget that each pot in each series received the same treatment, however, so that we still have comparative results.

Nevertheless it seems significant that rain brought down the temperature of July 7 to about $14-20^{\circ} \mathrm{C}$ from $16-30^{\circ} \mathrm{C}$ the minima and maxima of July 6 . On July 8 the temperature rose again. It was these series which directed my attention more particularly to the question of temperature, and no doubt much work will be needed before its full importance in infection is understood. When we find that the thermometer registers $3^{8-}-36^{\circ} \mathrm{C}$ in the sun, and that (see Table $\mathrm{X}$, p. 270) the spores will not germinate much above $25^{\circ} \mathrm{C}$, it seems likely that the young mycelium in the leaf will also be inhibited by the high temperatures, though we are ignorant of what the exact temperature inside the leaf may be.

In view of the evident failure of Nos. 747 and 754 it seemed necessary to examine somewhat more closely what conditions could be supposed to have affected the matter. Three points are concerned: the germination of the spores, the infection, and the incubation periods.

The spores were tested and were known to be vigorously 


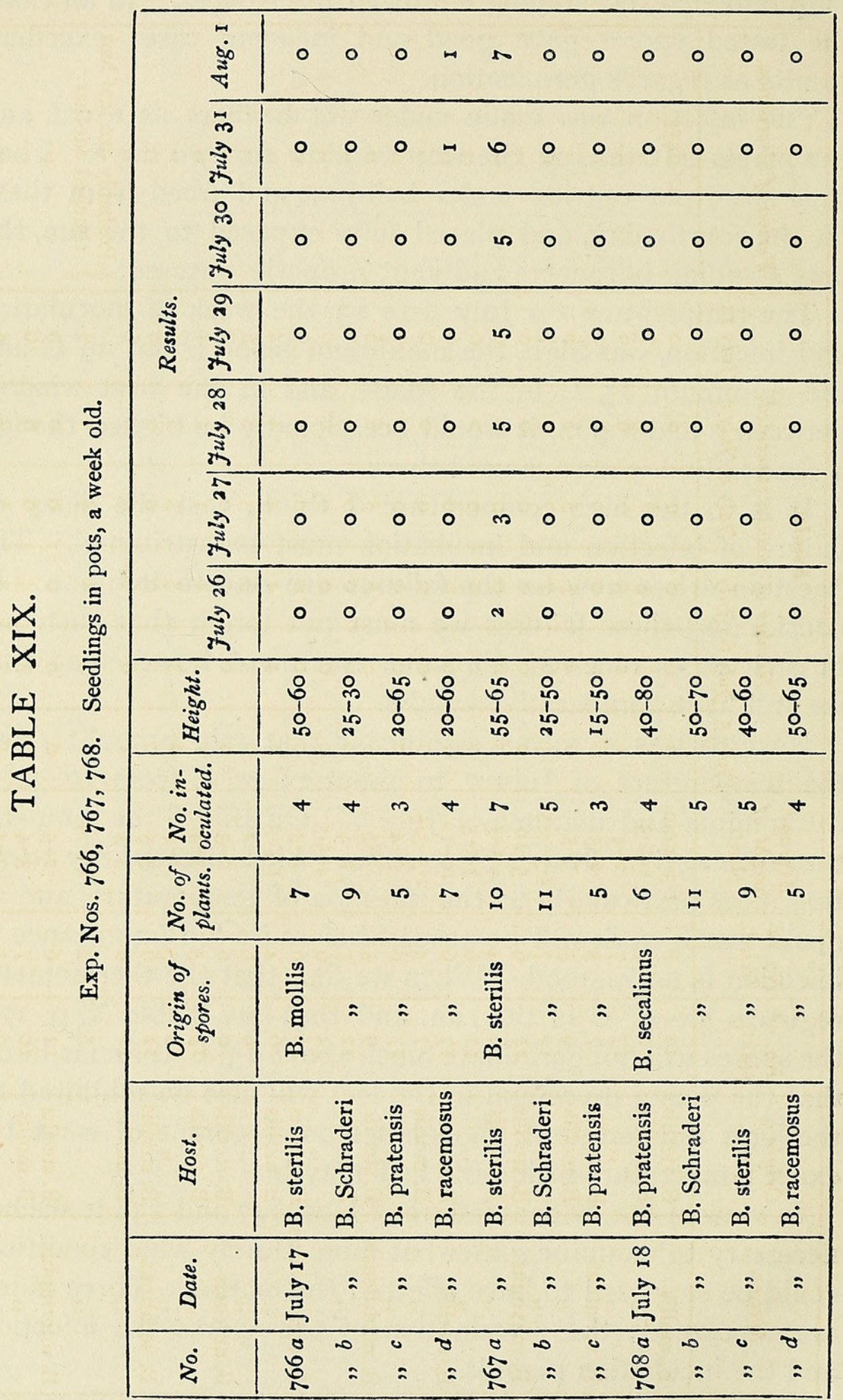




\begin{tabular}{|c|c|c|}
\hline 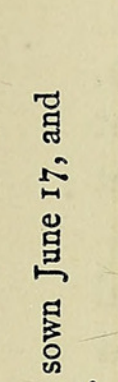 & 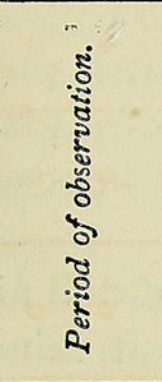 & 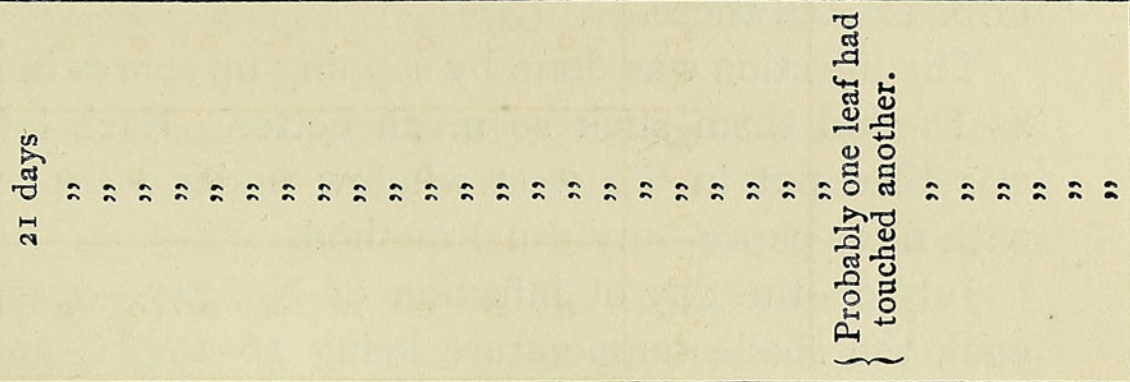 \\
\hline 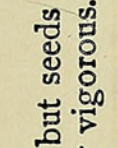 & $\underset{2}{3}$ & 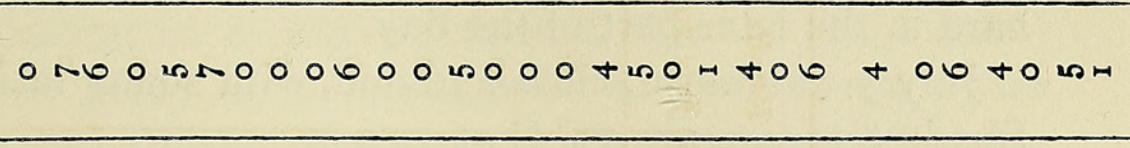 \\
\hline $\begin{array}{l}\hat{N} \\
\mathbb{N} \\
\overrightarrow{0}\end{array}$ & 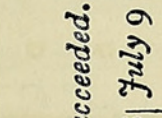 & 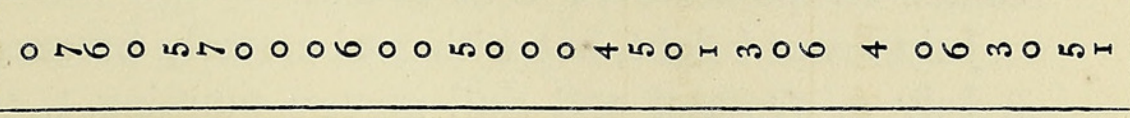 \\
\hline 焉 & 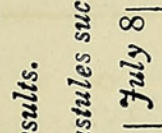 & 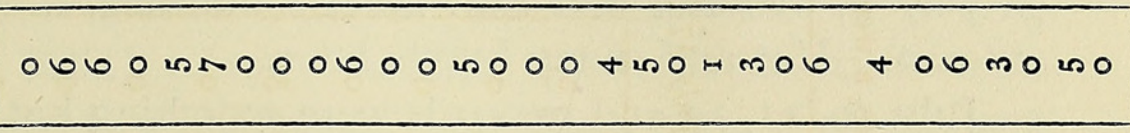 \\
\hline Nin & 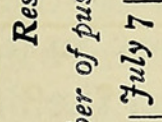 & 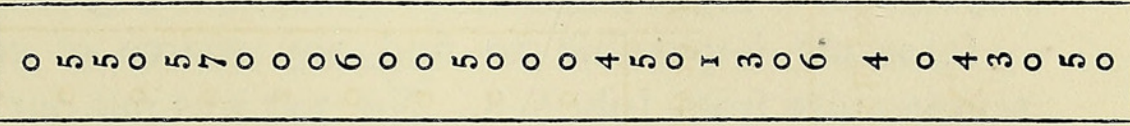 \\
\hline 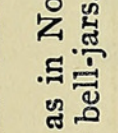 & 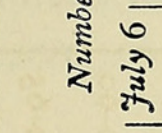 & 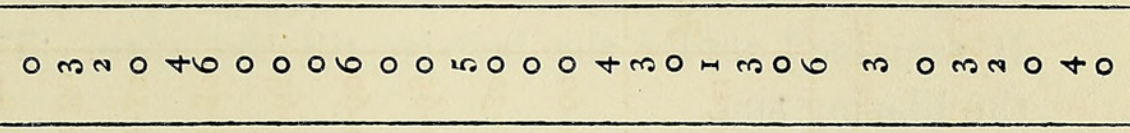 \\
\hline 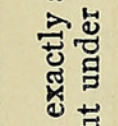 & 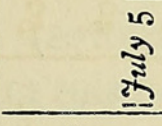 & 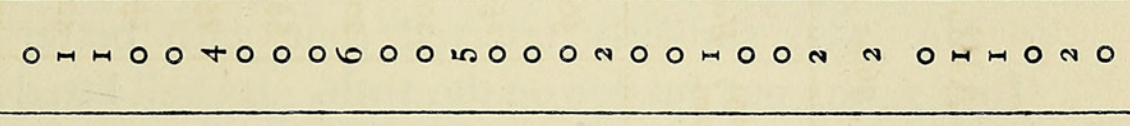 \\
\hline 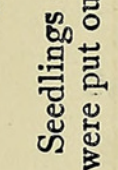 & 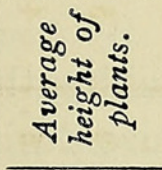 & 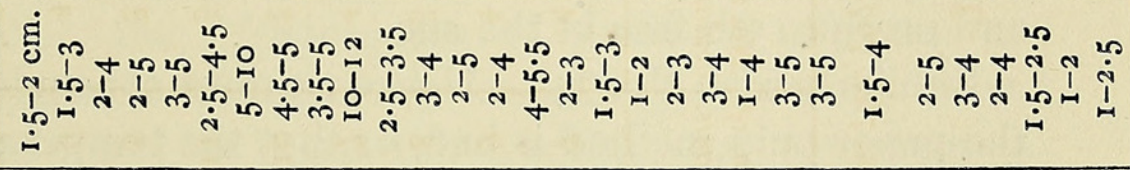 \\
\hline 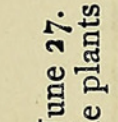 & 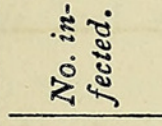 & 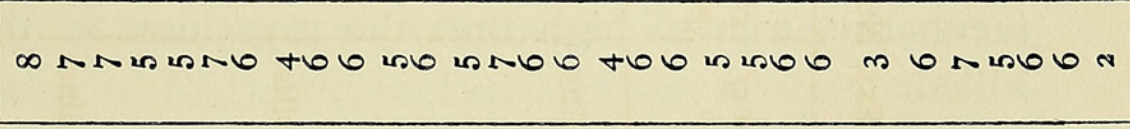 \\
\hline 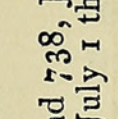 & 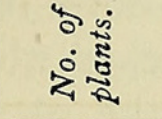 & 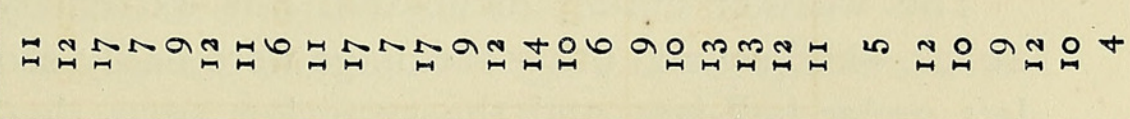 \\
\hline 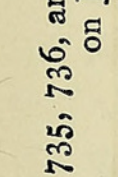 & 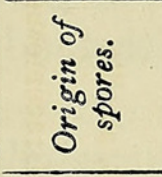 & 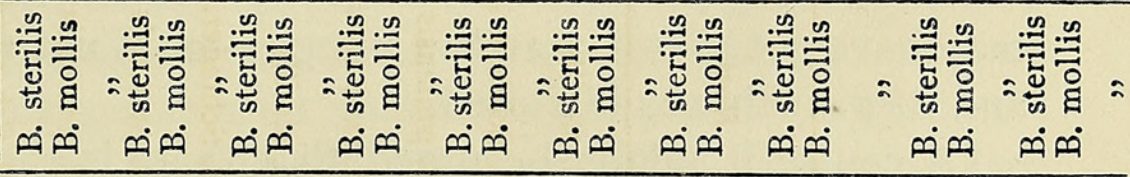 \\
\hline $\begin{array}{l}\dot{0} \\
\dot{0} \\
\dot{x} \\
\dot{x}=1\end{array}$ & $\begin{array}{l}\text { ֻँ } \\
\text { कूँ }\end{array}$ & 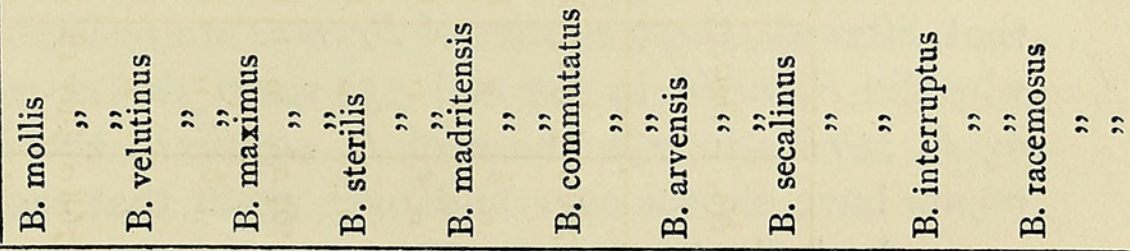 \\
\hline
\end{tabular}


germinating at $20-22^{\circ} \mathrm{C}$, so we may assume that no source of error existed there.

The infection was done by sopping up spores in paper pulp, as I found them stick so much better. Each infected plant was then put in the west window under a beaker kept wet with filter-paper-my usual method.

July 6-the day of infection of No. 747-opened dull and cool, the shade temperature being $16-19 \cdot 5^{\circ} \mathrm{C}$ and it rained hard in the later part of the day.

July 7 was warm, close and dull, with sunny intervals later. Shade temperature $22^{\circ} \mathrm{C}$ at Io a.m.

July 8 was bright, hot with cool easterly breezes.

July 9 , overcast and dull muggy morning, $\mathrm{t} .=\mathrm{I} 9.5^{\circ} \mathrm{C}$ at I I a.m. Hot and sunny bursts later.

July IO, I I, I 2 and onwards were scorching hot days.

It seems impossible to find any source of error in the temperature from July 6-8. No. 747 was put out on the 8th. It remained under the bell-jar till the Ioth. Then free in the blazing sun.

No. $75^{2}$, similarly infected (but with better spores) on July 7 , was put outside on the Ioth. Its bell lifted on the I I th and on the $I 3^{\text {th }}$ free in the sun.

Similarly with No. 754. Hence we must conclude either that the paper pulp method is bad, or that the temperature during incubation was so high that the mycelium in the leaf was killed.

The weather during incubation was extremely hot-July IO-2I-and several other seedlings were badly scorched when left under bell-jars, and the suspicion arose that the plants may have got so hot that the Fungus could not withstand it, and its growth was inhibited.

Of course it might be urged that there is the possibility that, after all, these species of Bromus are resistant-but if so why did $B$. mollis in 747 and $75^{2}$ resist the $B$. mollis spores, or $B$. sterilis in 754 those of $B$. sterilis? Previous experiments have shown over and over again that such a result is not to be looked for. 
That it was really the high temperature, and not the method of infection, however, seemed clear after the following experiments.

Three series (Nos. 759, 763, and 764) of the same hosts, \&c., as in the preceding lists, were infected by placing the spores in the tip-drops and on the face of the leaf, in water only. The temperature was very high, and all failed.

On the other hand, by adopting the precaution of carrying out the infection in a cool cellar, and allowing the incubation to take place in a well-lighted but cool area, where the temperature did not rise above $25^{\circ} \mathrm{C}$, I found the results quite comparable to those of the previous experiments before the very hot weather set in. See Tables XIX and XX, and Table XXII, p. 297. Similar successful infections were then obtained in a number of other cases, some of which have been shown in results already published ${ }^{1}$, and which are quite conclusive as to the state of affairs when the external conditions for infection are satisfactory.

\section{io. Discussion of the FOREgoing Results.}

There seems to be no doubt from the evidence now accumulated that the Uredospores of Puccinia dispersa are capable of germinating upon any leaf of any species of Bromus and putting forth the germ-tubes which seek the stomata. Here the tip of the germ-tube behaves differently according to the species of Bromus attacked and the species of hostplant whence the Uredospore has been derived.

If these species are identical-e. g., if Uredospores derived from Bromus mollis find the conditions for germination on leaves of Bromus mollis - the tip of the Uredospore swells up over the stoma, and soon puts forth a branch into the intercellular spaces beneath, and there ramifies as a mycelium which, in ten days or so, again puts forth pustules of Uredospores. Even here, however, the success of the mycelium depends on circumstances. If the temperature, light, supply of water and minerals, \&c., are unfavourable, and the leaf is

1 Proc. Cambridge Phil. Soc., vol. xi, Pt. V, p. 307. 


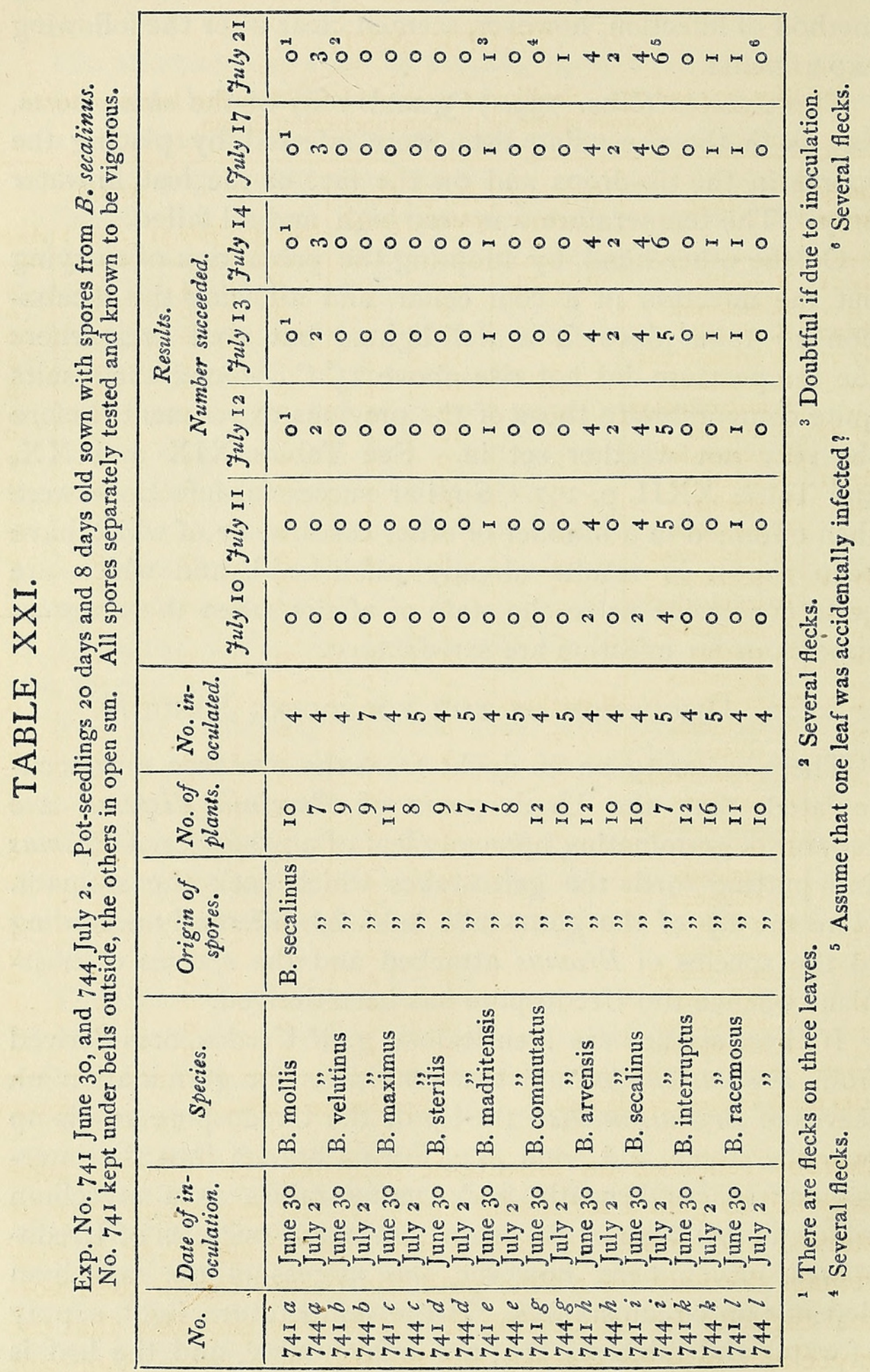




\section{TABLE XXII.}

Exp. Nos. 774 and 775. Seedlings a week old infected on first leaf with tested vigorous spores at temperature near optimum.

\begin{tabular}{|c|c|c|c|c|c|c|c|c|c|c|}
\hline No. & $\begin{array}{l}\text { Date of } \\
\text { infection. }\end{array}$ & Host. & $\begin{array}{l}\text { Origin of } \\
\text { spores. }\end{array}$ & $\begin{array}{l}\text { No. of } \\
\text { plants. }\end{array}$ & $\begin{array}{l}\text { No.in- } \\
\text { fected. }\end{array}$ & Fuly $3 \circ$ & f fuly $3 \mathbf{I}$ & $\begin{array}{l}\text { Results. } \\
\text { Aug. I }\end{array}$ & Aug. 2 & Aug. 4 \\
\hline $774 a$ & July 2 I & B. mollis & B. mollis & I0 & 5 & 3 & 4 & 5 & 5 & 5 \\
\hline$" \| b$ & 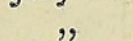 & B. tectorum & " & 8 & 4 & 0 & 0 & 0 & 0 & o \\
\hline$\Rightarrow \quad c$ & July 22 & B. ciliaris $^{1}$ & ", & 8 & 5 & 0 & o & o & $\circ$ & $\circ$ \\
\hline$" \quad d$ & July 2 I & B. brizaeformis & $"$ & II & 5 & 2 & 2 & 2 & 2 & 2 \\
\hline & $"$ & B. secalinus & ", & I0 & 5 & 3 & 3 & 4 & 5 & 5 \\
\hline$" f$ & " & B. macrostachys & $"$ & 9 & 5 & $\circ$ & 4 & 4 & 4 & 4 \\
\hline$\Rightarrow g$ & July 22 & B. inermis & ", & IO & 5 & 0 & $\circ$ & 0 & o & $\circ$ \\
\hline$" h$ & 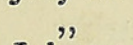 & B. pratensis ${ }^{2}$ & ", & 9 & 5 & $\circ$ & $\circ$ & $\circ$ & $\circ$ & o \\
\hline " $i$ & July 2 I & B. velutinus & $"$ & 7 & 4 & $\circ$ & 2 & 3 & 3 & 3 \\
\hline$", k$ & $"$ & B. sterilis & ", & 6 & 4 & o & $\circ$ & o & o & o \\
\hline$\Rightarrow l$ & $"$ & B. maximus & $"$ & 7 & 4 & 0 & 0 & o & $\circ$ & o \\
\hline " $m$ & & B. madritensis & ", & 9 & 4 & $\circ$ & o & $\circ$ & 0 & $\circ$ \\
\hline$" n$ & July 22 & B. Schraderi ${ }^{3}$ & , & II & 5 & $\circ$ & o & $\circ$ & $\circ$ & $\circ$ \\
\hline & " & B. unioloides ${ }^{3}$ & ", & 3 & 2 & 0 & 0 & o & o & o \\
\hline$\# p$ & $"$ & B. canadensis & ", & 2 & 2 & o & 0 & o & $\circ$ & $\circ$ \\
\hline$\Rightarrow \quad q$ & " & B. erectus & ", & 4 & 2 & $\circ$ & $\circ$ & $\circ$ & 0 & $\circ$ \\
\hline & $"$ & B. giganteus & & I & I & 0 & 0 & 0 & 0 & $\circ$ \\
\hline $775 a$ & $"$ & B. mollis & B. secalinus & 7 & 4 & $\circ$ & o & $\circ$ & o & 0 \\
\hline$" \Rightarrow b$ & ", & B. tectorum & ," & 6 & 4 & $\circ$ & $\circ$ & 0 & o & $\circ$ \\
\hline , $c$ & $"$ & B. ciliaris & ", & 9 & 5 & 0 & $\circ$ & $\circ$ & $\circ$ & $\circ$ \\
\hline$" d$ & " & B. brizaeformis & , & 8 & 5 & $\circ$ & $\circ$ & 3 & 3 & 3 \\
\hline ", $e$ & $"$ & B. secalinus & ", & 9 & 6 & 3 & 4 & 6 & 6 & 6 \\
\hline$" f f$ & $"$ & B. macrostachys & ", & 9 & 5 & 5 & 5 & 5 & 5 & 5 \\
\hline$" g$ & " & B. inermis & ", & 8 & 5 & o & o & $\circ$ & $\circ$ & 0 \\
\hline$", h$ & $"$ & B. pratensis & $"$ & 6 & 4 & $\circ$ & $\circ$ & $\circ$ & 0 & o \\
\hline & ", & B. velutinus & , & IO & 5 & $\circ$ & 3 & 4 & 4 & 4 \\
\hline$\# k$ & ", & B. sterilis & ", & 6 & 4 & $\circ$ & 0 & o & o & o \\
\hline$", l$ & ", & B. maximus & , & 6 & 4 & $\circ$ & o & $\circ$ & $\circ$ & $\circ$ \\
\hline \# $m$ & , & B. madritensis & , & 7 & 4 & 0 & 0 & $\circ$ & 0 & $\circ$ \\
\hline$" n$ & , & B. Schraderi & , & 8 & 4 & 0 & 0 & $\circ$ & 0 & 0 \\
\hline$" 0$ & ", & B. unioloides & ", & 2 & 2 & $\circ$ & $\circ$ & o & $\circ$ & o \\
\hline & " & B. canadensis & , & 2 & 2 & 0 & $\circ$ & 0 & $\circ$ & $\circ$ \\
\hline
\end{tabular}

1 Species needs further examination.

${ }^{2}$ Species needs revision.

${ }^{3}$ Synonyms.

thereby rendered an unsuitable medium, the infecting tube may fail to gain a successful entry, or the mycelium may be starved and unable to form a new crop of spores, or it may remain dormant for a time until the tissues regain their normal capacity for supporting it. It is even probable that the mycelium may be starved out by the, in a sense, dominant tissues of the host-plant, when itself very feeble, if the 
latter regain their vigour, and thus the infection becomes abortive.

If the Uredospores germinate on a leaf of some other species of Bromus than the one which bore them,-e.g., if spores from $B$. mollis germinate on leaves of $B$. sterilis-the infection may be rendered abortive, owing to the non-adaptation of the parasite to the host, in other ways. Thus the infecting tube may attack the stomata and underlying cells too vigorously, as it were. In this case the cells first attacked die, and the dead tissues are so unsuitable as pabulum for the incipient mycelium, that the latter dies off from starvation, a corroded patch showing where the injury is localized. This appears to be a common event when the tips of the young leaves of $B$. sterilis, $B$. madritensis, or $B$. maximus are invaded by vigorous spores derived from $B$. mollis.

In such cases the non-adaptation of the parasite to its new host is shown, not by any active resistance of the latter, but by the too vigorous onslaught of the former producing such disastrous results that the mycelium cannot advance through the ruined tissues its ill-timed ravages have brought about.

In sections of such, the short stumpy mycelium, with fatty contents suggesting a starved condition, may be observed among the dead and dying cells of the leaf-tissue, evidently unable to grow.

Yet another case of non-adaptation of the parasite appears to occur when the Uredospores from one species attack a species unsuitable to them, e.g., when spores from $B$. mollis germinate on the leaves of $B$. inermis or of $B$. erectus, \&c.

In these cases it seems that the infecting tubes reach and penetrate the stomata, but are unable to form a mycelium in the tissues, evidently because the living cells are really resistant. How the latter prevent the hyphae from putting haustoria into their cell-cavities is not yet clear, but it looks as if they exerted some deleterious influence on the delicate tips and thus brought their efforts to abortion.

It will be obvious that the foregoing explanation of the phenomena differs entirely from Eriksson's Mycoplasm hypo- 
thesis. The dormant mycelium is dormant not because it has established a symbiosis with the host, but because it has failed to establish any such relations. It is like a plant in poor soil, or in a medium too dry or too cold, \&c., for its welfare. It drags on a starved, stunted existence which will end in death unless the environment improves, and nurses it again into vigorous growth. We must rather consider the flourishing mycelium, fully adapted to its host-plant, as having established successful symbiotic relations, for, as I pointed out long ago, a Uredine when flourishing in a leaf does not act as a devastating parasite, but as one which slowly taxes its host, and even stimulates the cells for some time to greater activity. This is often shown by the persistent green colour and activity of the cells immediately round a pustule at a time when the rest of the leaf is yellow and faded. The same conclusion is borne out by the well-established fact that the best developed pustules and Uredospores are derived from the most flourishing green leaves. In other words, we get a better nourished and better developed mycelium in a leaf which can supply it with plenty of food; just as we get a finer plant by cultivating it highly in good soil and surroundings.

It will be observed that I lay some stress on the origin of the spores, a point far too much overlooked in all discussions regarding these parasites. Most observers have seemed to regard adapted parasitism as if it concerned chiefly the Fungus. I look upon the influence of its host as an equally important factor: though here and there the Fungus also varies from the normal.

The Uredospores derived from Bromus mollis attack the leaves of another plant of $B$. mollis so successfully because their food-supplies and previous environment have affected their protoplasm in some way which makes it easier for their germ-tubes and mycelium to grow in tissues which afford them the same nutriment and present the same obstacles, \&c., as they have hitherto enjoyed, or been confronted with.

They can also flourish in B. secalinus, B. racemosus, B. commutatus, because here also the food-supplies, \&c. offered are 
nearly the same-these species being so closely allied as to be regarded by some authorities as mere varieties.

But matters are different when it comes to attacking B. maximus, B. sterilis, \&c. We may suppose the food and the resistances offered to the mycelium by these species to differ considerably from those which existed in the tissues of $B$. mollis, though not perhaps sufficiently so to present a barrier incapable of being overcome by an odd spore varying from the normal here and there.

I regard this matter as exactly similar in kind (however different in degree it may be) to that where a carbo-hydrateloving Fungus is sown on a proteid, or when a Yeast adapted to one kind of sugar is placed in another kind, or where we attempt to rear dung-fungi on gelatine, wood-fungi on potato, and so forth. Numerous other illustrations can be given, but, not to multiply analogies unnecessarily, I will merely refer to the well-known case of Bacteria, distinct races of which can be produced by slight differences of nutrition and training.

Such cases also remind us that it is possible to educate a given Fungus or Bacterium to feed on very different media by gradually accustoming it to the changed conditions; and I suppose that when the Uredospores from $B$. mollis are sown on $B$. secalimus and $B$. racemosus as well as $B$. mollis, and find that it does best on the latter, next best on $B$. secalinus, and worst on B. racemosus, that such 'education' is substantially what is occurring, because if I now take the Uredospores developed in consequence of this infection on B. secalinus and sow them on the same three species, it is B. secalinus which proves the best host for them.

It is indeed very probable that by gradual variation and adaptation the Fungus can pass to all or nearly all the species of Bromes in turn, even to such as have hitherto appeared immune.

That by gradual passage from variety to variety, and from one species to a closely allied one, such spores may be gradually adapted to different hosts in nature, seems an obvious corollary from the facts. 


\section{in the Bromes and their Brown Rust. $30 \mathrm{I}$}

To sum up, then, I should place in the foreground the fact that three phases must be considered in infection :

(I) The germination of the Uredospore.

(2) The act of inoculation or infection; and

(3) The incubation period or growth of the mycelium in the tissues.

Each of these phases has its vicissitudes. The germination depends on the vigour and previous nutrition of the spore, as well as on the factors of the environment active during the process ; and the nature and vigour of the resulting germ-tube are determined especially by these.

The act of inoculation, or entry of the germ-tube into a stoma, brings into play new factors; for the living cells attacked, with their known capacities for producing acids, enzymes, food-stuffs, chemotactic substances, \&c., cannot be regarded as passive. It depends on these whether the germtube can gain a safe entrance. It may be so well adapted that this is easy, e. g., from $B$. mollis to $B$. mollis, or it may be that the over-energetic germ-tube destroys the guard-cells, \&c., and so ruins the affair at the start, e.g., from $B$. mollis to B. sterilis.

Once inside, the young mycelium is still by no means assured of successful development and growth. Even in a host-species naturally accommodating, e. g. $B$. mollis to the Fungus from $B$. mollis, a lack of minerals, especially potassium or phosphorus, may bring about slow starvation; or the temperature may be too high for the Fungus, though the grass itself withstands it well; or the host is so shaded that it assimilates badly and so forth. All these and similar events will have their effect, and the starved mycelium may die or lie dormant till the leaf dies, or possibly be resuscitated again if affairs improve before the life of the leaf is ended.

It seems to me that many cases of delayed outbreak of the Fungus, of apparent failure of attack, of poorly developed pustules, and of feebly germinating spores are to be explained by the above considerations.

When the invading germ-tube finds itself in the leaf of 
a species which differs so much from the one on which the Fungus giving rise to the Uredospores was raised, that the incipient mycelium has to accept food-supplies differing considerably from those on which it was brought up, and to face antagonistic influences of other kinds, enzymes and possibly anti-toxins, \&c., on the part of the cells it is in contact with, it may be dominated entirely, and the infection fails. Or it may just manage to struggle along and even to develop a few feeble spores, and it may depend on the vigour of these latter whether the reinfection of this species can occur, and so on.

\section{FACTORS IN THE HOST.}

It is evident that some factor or factors on the part of the host-plant must be concerned in rendering infection successful, or the reverse; because, as we have seen, even when the external conditions are favourable to germination, and even when spores have successfully germinated on the leaf, and the germ-tubes reached the stomata, infection only follows in the case of certain species or varieties, while others are 'resistant' if not 'immune.' The question thus arises, In what does this capacity for ' resistance,' or 'immunity,' consist ?

Several possibilities may be suggested in answer. The cell-walls might be supposed to be too thick for the hyphae, even when safely ensconced in the inter-cellular passages, to penetrate them; or the stomata may be imagined to be too small for the tip of the tube to force its way in ; or the hairs on the epidermis may be a hindrance, and so forth. In most of the few cases where such questions have arisen, some such anatomical hindrances to infection have been suggested, and in at least one similar instance-that of wheat-rust, such anatomical hindrances to infection have been asserted ${ }^{1}$ and denied ${ }^{2}$ by different observers.

But it is obvious that no mere direct examination of the structure can be expected to supply a sufficient answer to such questions, and still less that speculative suggestions

1 Cobb, Agric. Gaz. N. S. Wales, vol. iii, I892, p. I.

2 Eriksson, Die Getreideroste, 1896, p. 35 I. 


\section{in the Bromes and their Brown Rust. 303}

should do so. I have accordingly gone into this question of the structural peculiarities of the host-plant in a manner more searching and thorough than hitherto, and have, I believe for the first time, devised methods of attacking the question which promise accurate results, which results, moreover, are perhaps somewhat surprising in their nature.

This part of the investigation has, as will readily be understood from the sequel, proved a very laborious, not to say tedious, business, but it was obvious that it had to be done; and although I am not prepared to state that all the numerous measurements and calculations are accurate and final, it will be seen that they hang together sufficiently firmly to make a chain of evidence which seems to support the main conclusion, which is, that the resistance to infection of the 'immune' or 'partially immune' species and varieties is not to be referred to observable anatomical or structural peculiarities, but to internal, i.e. intra-protoplasmic, properties beyond the reach of the microscope, and similar in their nature to those which bring about the essential differences between species and varieties themselves.

The problem which I set myself was, to investigate as thoroughly as possible the sizes, numbers, and distribution of the stomata, hairs, chlorophyll-tissue, vascular bundles, sclerenchyma and other structural units of the leaf, and to see if in any two or more species or varieties of Brome such structural relations showed differences at all compatible with differences in their predisposition to the disease or to their immunity from infection.

In order that no avoidable complications should be introduced owing to variations on the part of individuals grown under different conditions, or in different leaves or parts of leaves, I adopted the precaution of selecting for examination of these structural factors the same part of the same leaf, grown under the same conditions. Not only so, I took this leaf from the pots of two of the most conclusive sets of experiments, viz. Nos. 774 and 775 (see Table XXII), in the following manner. 
When, on August 4, I made the last records of the results of infection of the two series named, the first green leaf of both the infected and uninfected seedlings from each pot was removed, and put into tubes of absolute alcohol and of Fleming's solution. Each tube received also a cardboard slip with the serial experiment-number, name of the species, and date. These tubes were then put aside (the specimens in Fleming's solution having been properly hardened, washed and transferred to absolute alcohol) to await examination during the autumn and winter. Meanwhile, notes were accumulated as to the length, breadth, number of ribs, thickness, height of ridges and so on of the fresh leaves, in order that future comparisons could be made, in case any question arose during the examination of the preserved material.

In due course, the examination was made as follows. The upper part-three centimetres or so in length-of each leaf was taken, and examined as follows. The uppermost centimetre (apex) was removed and the rest cut into short lengths of about three to four millimetres. One of these was mounted with its upper face upwards, and its next segment with its lower face upwards on the same slide. Various methodsbalsam, glycerine, glycerine-jelly, warming in eau-de-javelle, \&c., were tested, but the most satisfactory results were obtained by transferring through warmed glycerine and alcohol to glycerine jelly.

These translucent preparations were then examined for such details as the breadth of the leaf, the number of ribs and their distances apart, the number and size, distribution, \&c., of hairs, stomata, and so forth.

The remaining segments were employed to obtain transverse sections, similarly mounted and used for measurements of the thickness, breadth, \&c., of the leaf, the vascular bundles, chlorophyll-tissue, \&c., as well as to check the preceding measurements.

The results are set forth in the accompanying Tables. I may here state that no measurable differences in the thick- 


\section{in the Bromes and their Brown Rust. 305}

ness of the cell-walls, cuticle, waxy bloom, \&c., were obtained, and these factors are omitted from the Tables.

\section{General Anatomy of the First Green Leaf.}

In all the species examined the first green leaf of the seedling is ligulate, acute, and slightly hooded at the apex, varying in length from $40-50$ to $80-100 \mathrm{mms}$. and inrolled at the base. The length is not sufficiently constant to be of service as a character, but the breadth, from $\mathrm{I}-3 \mathrm{mms}$., is remarkably so, as the table of measurements shows.

The mid-rib always contains the strongest vascular bundle, and has a keel-which may be very slight however-subtending it. This is flanked by one, two, or three ribs on each side, according to the species, in each of which a weaker bundle runs. Thus $B$. mollis, $B$. arvensis, $B$. interruptus, \&c., have usually three ribs in all, $B$. secalinus, $B$. sterilis, \&c., have five, while $B$. maximus, $B$. unioloides, \&c., have seven. It appears to be constantly the case also that each alternate rib contains a feebler vascular bundle; for instance, where there are three in all, the strong mid-rib is flanked by a weaker one on either side; when five are present, those nearest the margins are stronger than those between them and the midrib; and when there are seven in all, the second from the margin on each side is stronger than those on either side of it.

Corresponding to each rib is a ridge, i. e. the tissue of the leaf is thicker especially above (but also below) than in the intervals, and we thus have a series of intervening grooves alternating with ridges, especially on the upper surface of the leaf. It is in the tissue beneath these grooves that the chlorophyll is aggregated.

It is on the flanks of these ridges, and only there, that the stomata occur. These are arranged in longitudinal series, usually a single series on each flank of the ridge, but occasionally double (and, rarely, even triple) on one flank of one ridge on each half of the lamina.

There is no exception, in the cases examined, to the rule 
that the stomata are more numerous on the upper surface than on the lower, the increased numbers being due to closer packing of the stomata in each longitudinal series, and occasionally to an increase in the number of series above. The stomata are large, and always placed with the long axis coinciding with that of the longitudinal series. As a rule the stomata are somewhat larger on the lower than on the upper surface, and account has to be taken of some variation in the extremes of size: the majority, however, are of an average size between these extremes.

Hairs are never totally absent, though they vary enormously in abundance, and the rule is almost without exception that they are more numerous and often much more numerous below than above, thus reversing the order of events found in the case of the stomata.

As regards the length of the hairs, considerable variation is also evident, though sufficient constancy as regards average length is found in each species to make it worth while noting the character. The hairs are always simple and usually stiff and tapering, and arise from the crests of the ridges on the upper surface of the leaf, but from the flanks or from the intervals (grooves) between the ridges on the lower surface. On the latter, moreover, there is no recognizable order in their arrangement, and beyond a sort of general rule that a stoma and a hair do not usually occur close together I have been unable to observe any very definite relation between these organs. At the same time it appears probable that in their inception there is some more or less definite order of succession, but since I have paid very little attention to the youngest stages, the matter must remain undecided.

All the Bromes examined have motor-cells in the grooves between the ridges on the upper surface; there are none on the lower. These motor-cells are merely enlarged and turgescent epidermal cells, the contraction and expansion of which draws together or drives apart the ridges of the upper surface, thus bringing about corresponding infolding or expansion of the leaf. The mechanism is easily seen in the behaviour of 
TABL]

Dimensions of leaf. The black lines in colt

\begin{tabular}{|c|c|c|c|c|c|c|c|c|c|c|c|c|}
\hline \multirow{2}{*}{$\begin{array}{c}\text { Species of } \\
\text { Bromus. }\end{array}$} & \multirow{2}{*}{$\begin{array}{c}(1) \\
\text { Width of } \\
\text { leaf: } \\
\text { direct } \\
\text { measure- } \\
\text { ment. }\end{array}$} & \multirow{2}{*}{$\begin{array}{l}\text { (2) } \\
\text { No. } \\
\text { of } \\
\text { ribs. }\end{array}$} & \multicolumn{9}{|c|}{$\begin{array}{l}\text { (3) } \\
\begin{array}{c}\text { Distances between the ribs measured from axis to axis } \\
\text { direct (low power). }\end{array}\end{array}$} & \\
\hline & & & $\begin{array}{c}\text { Margin } \\
\text { to No. I }\end{array}$ & $I-2$ & $2-3$ & $3-4$ & $4-5$ & $5^{-6}$ & $6-7$ & $\begin{array}{l}\text { No. } 7 \text { to } \\
\text { margin. }\end{array}$ & Total $\mu$. & $\begin{array}{l}M_{c} \\
\text { to } 1\end{array}$ \\
\hline B. mollis & I. $2 \mathrm{~mm}$ & 3 & 192 & 390 & 402 & 210 & & & & & II 94 & \\
\hline B. tectorum & $\mathrm{I} \cdot 7$ & 5 & 162 & $35^{8}$ & $35^{8}$ & $3^{12}$ & 325 & I 43 & & & $16_{57}$ & \\
\hline B. ciliatus & $\mathrm{I} \cdot 8$ & 5 & 169 & 357 & 390 & 325 & 325 & I 43 & & & 1709 & \\
\hline B. brizaeformis & 2.0 & 5 & 162 & 325 & $33^{8}$ & 345 & $33^{8}$ & I75 & & & 1683 & \\
\hline B. secalinus & $2 \cdot 4$ & 5 & 260 & 455 & 455 & 455 & 455 & 260 & & & 2340 & \\
\hline B. macrostachys & $1 \cdot 9$ & 5 & $22 \mathrm{I}$ & 357 & 390 & 390 & 325 & I 95 & & & 1878 & \\
\hline B. pratensis & & & & & & & & & & & & \\
\hline B. inermis & I. 2 & 5 & 143 & 293 & 292 & 292 & 293 & 98 & & & $I_{4} \mathrm{II}$ & \\
\hline B. velutinus & $2 \cdot 0$ & 5 & 227 & $39^{\circ}$ & $39^{\circ}$ & $39 \mathrm{I}$ & 390 & 227 & & & 2015 & \\
\hline B. sterilis & $2 \cdot 0$ & 5 & 228 & 377 & $35^{\mathrm{I}}$ & 325 & 364 & 195 & & & 1840 & \\
\hline B. maximus & $3 \cdot 0$ & 7 & I 95 & 325 & 520 & 520 & 520 & 520 & $39^{\circ}$ & 169 & 3159 & \\
\hline B. madritensis & I.7 & 5 & 182 & $33^{8}$ & 325 & 325 & $35^{\mathrm{I}}$ & 169 & & & 1690 & \\
\hline B. Schraderi & 2.I & 7 & I3O & 292 & 325 & 325 & 325 & 325 & 260 & 130 & $2 \operatorname{II} 2$ & \\
\hline B. unioloides & 2.5 & 7 & 162 & 293 & $33^{8}$ & $33^{2}$ & 326 & $39^{\circ}$ & 299 & 163 & $23 \circ 3$ & \\
\hline B. racemosus & $\mathrm{I} \cdot 75$ & 5 & 196 & $3^{6} 5$ & 330 & 330 & 360 & 220 & & & $180 I$ & \\
\hline B. commutatus & I.I & 3 & 160 & $4^{16}$ & 420 & 190 & & & & & I 186 & \\
\hline B. interruptus & 1.0 & 3 & 160 & $37 \mathrm{I}$ & 352 & 160 & & & & & 1043 & \\
\hline B. arvensis & I. 2 & 3 & I92 & 360 & 384 & 172 & & & & & I 108 & \\
\hline B. canadensis & $\mathrm{I} \cdot \mathrm{7}$ & 5 & 195 & 325 & 325 & 325 & 325 & 162 & & & $16_{57}$ & \\
\hline
\end{tabular}

Ann. Bot., Vol. XVI. To face p. 307.] 
1. 4 indicate the position of the mid-rib.

(4)

inces between ribs measured on transverse sections of leaf.

\begin{tabular}{|c|c|c|c|c|c|c|c|c|c|c|c|}
\hline \multicolumn{7}{|c|}{ sections of leaf. } & \multirow{2}{*}{$\begin{array}{c}\text { total } \\
\text { breadth } \\
\text { of ribs } \\
\text { (sections). }\end{array}$} & \multirow{2}{*}{$\begin{array}{l}\text { Depth of } \\
\text { mid-rib. }\end{array}$} & \multirow{2}{*}{$\begin{array}{c}\text { Depth } \\
\text { at } \\
\text { Sinus. }\end{array}$} & \multirow{2}{*}{\multicolumn{2}{|c|}{$\begin{array}{l}\text { area of chloro- } \\
\text { phyll tissue per } \\
\text { mm. of breadth. }\end{array}$}} \\
\hline $2-3$ & $3-4$ & $4-5$ & $5^{-6}$ & $6-7$ & $\begin{array}{l}\text { No. } 7 \text { to } \\
\text { margin. }\end{array}$ & Total $\mu$. & & & & & \\
\hline 423 & I 88 & & & & & I $24 \mathrm{I}$ & 237 & 260 & I 50 & IIO & 88,990 \\
\hline 455 & 435 & $4^{23}$ & 324 & & & 2300 & 224 & $3^{2} 5$ & I $5^{2}$ & 238 & 214,200 \\
\hline $4^{2} 3$ & $4^{29}$ & 422 & I 40 & & & 2083 & 224 & 260 & I 30 & 195 & I74,030 \\
\hline 337 & 337 & 345 & 162 & & & 1720 & I98 & 260 & 127 & I93 & I7I,770 \\
\hline $4^{6} \mathrm{I}$ & $44^{8}$ & $44^{2}$ & $24 I$ & & & 2314 & 300 & 325 & $I_{5}$ I & $23^{8}$ & 207,060 \\
\hline 325 & $3^{2} 5$ & 325 & I95 & & & 1710 & 210 & 293 & 146 & 219 & 192,063 \\
\hline 305 & 3 II & 305 & I82 & & & I 584 & 2 I 8 & 260 & II 7 & I 88 & ${ }^{\text {I }} 55,35^{8}$ \\
\hline 409 & 390 & 390 & 260 & & & 2 I 84 & 236 & $34^{2}$ & I 33 & 237 & 201,190 \\
\hline 423 & 468 & 455 & 253 & & & 2294 & 243 & 293 & IOI & I97 & I $76,3^{1} 5$ \\
\hline 520 & 520 & 520 & 507 & $33^{8}$ & I 82 & $3^{192}$ & $4^{10}$ & 325 & 147 & 236 & 205,685 \\
\hline 305 & 325 & 325 & I95 & & & 1670 & I92 & $2 \mathrm{I} 4$ & I 20 & 203 & I 79,655 \\
\hline 312 & $3^{2} 5$ & $33^{8}$ & 292 & 260 & I 30 & 2067 & 333 & I 88 & 100 & I 44 & I 20,808 \\
\hline 390 & 403 & 390 & 390 & 325 & 162 & 2606 & 327 & 260 & I 49 & 204 & I 78,402 \\
\hline $37 \mathrm{I}$ & 345 & $3^{84}$ & 262 & & & 2059 & 249 & 288 & I 20 & 204 & I 79,3 I 6 \\
\hline 350 & 160 & & & & & 1035 & 134 & 224 & 109 & 166 & $I_{44,420}$ \\
\hline 439 & 198 & & & & & 1263 & 147 & 268 & 122 & 195 & $172,3 \circ 3$ \\
\hline 371 & 192 & & & & & I I 45 & I 34 & 262 & 96 & I 79 & I 55,857 \\
\hline 3 I 2 & 306 & 312 & 195 & & & 1697 & 269 & 273 & 162 & 217 & I 82,497 \\
\hline
\end{tabular}

(5)

(6)

(7) $\mid(8$

(9)

Average

breadth

of ribs

(6)

(8)

Mean sectional

area of chloro-

phyll tissue per

mm. of breadth.

(sections). 

TABLE NIII.

Dimensions of leaf. The black lines in collm 4 indicate the position of the mid-rib.

\begin{tabular}{|c|c|c|c|c|c|c|c|c|c|c|c|c|c|c|c|c|c|c|c|c|c|c|c|c|}
\hline \multirow{2}{*}{$\begin{array}{l}\text { Species of } \\
\text { Bromus. }\end{array}$} & \multirow{2}{*}{$\begin{array}{c}(1) \\
\text { Width of } \\
\text { leaf: } \\
\text { direct } \\
\text { measure- } \\
\text { ment. }\end{array}$} & \multirow{2}{*}{$\begin{array}{l}\text { (2) } \\
\text { No. } \\
\text { of } \\
\text { ribs. }\end{array}$} & \multicolumn{9}{|c|}{$\begin{array}{l}\text { Distances between the ribs measured from axis to axis } \\
\text { direct (low power). }\end{array}$} & & \multicolumn{7}{|c|}{$\begin{array}{l}\text { (4) } \\
\text { Yances between ribs measured on transverse } \\
\text { sections of leaf. }\end{array}$} & \multirow{3}{*}{$\begin{array}{c}(5) \\
\text { Average } \\
\text { total } \\
\text { breadth } \\
\text { of ribs } \\
\text { (sections). } \\
237\end{array}$} & \multirow{3}{*}{$\frac{\begin{array}{l}\text { Depth of } \\
\text { mid-rib. }\end{array}}{260}$} & \multirow{3}{*}{$\begin{array}{c}(7) \\
\\
\text { Depth } \\
a t \\
\text { Sinus. } \\
\\
{ }_{5}{ }^{\circ}\end{array}$} & \multirow{2}{*}{\multicolumn{2}{|c|}{$\begin{array}{l}\text { (8) } \\
\text { Mean sectional } \\
\text { area of chloro- } \\
\text { phyll tissue per } \\
\text { mm. of breadth. }\end{array}$}} \\
\hline & & & $\begin{array}{l}\text { Margin } \\
\text { to No. I }\end{array}$ & $I-2$ & $2-3$ & $3-4$ & $4-5$ & $5^{-6}$ & $6-7$ & $\begin{array}{l}\text { No. } 7 \text { to } \\
\text { margin. }\end{array}$ & Total $\mu$. & $\begin{array}{l}\text { Margin } \\
\text { to } N_{0} \text {. }\end{array}$ & $1-2 \mid 2-3$ & $3-4$ & $4-5$ & $5^{-6}$ & $6-7$ & $\begin{array}{l}\text { No. } 7 \text { to } \\
\text { margin. }\end{array}$ & Total $\mu$ & & & & & \\
\hline B. mollis & $\mathrm{I} .2 \mathrm{~mm}$. & 3 & $19^{2}$ & $39 \circ$ & 402 & 210 & & & & & II 94 & $\mathrm{I} 95$ & $4351_{423}$ & 388 & & & & & I $24 \mathrm{I}$ & & & & IIO & 88,990 \\
\hline B. tectorum & $\mathrm{I} \cdot 7$ & 5 & 162 & $35^{8}$ & $35^{8}$ & 312 & $3^{25}$ & 143 & & & $16_{57}$ & 234 & 49455 & 435 & $4^{23}$ & 324 & & & 2300 & 224 & 325 & ${ }^{1} 5^{2}$ & $23^{8}$ & 214,200 \\
\hline B. ciliatus & I. 8 & 5 & 169 & 357 & $39^{\circ}$ & 325 & $3^{2} 5$ & I 43 & & & 1709 & 227 & $4^{2} 4^{23}$ & 3429 & 422 & 140 & & & 2083 & 224 & 260 & I 30 & I95 & ${ }^{174,030}$ \\
\hline B. brizaeformis & 2.0 & 5 & 162 & 325 & $33^{8}$ & 345 & $33^{8}$ & I75 & & & 1683 & $\mathrm{I} 95$ & & 337 & 345 & 162 & & & 1720 & $19^{8}$ & 260 & 127 & I93 & I $71,77^{\circ}$ \\
\hline B. secalinus & 2.4 & 5 & 260 & 455 & 455 & 455 & 455 & 260 & & & 2340 & 247 & 475461 & $44^{8}$ & $44^{2}$ & $24^{I}$ & & & 2314 & 300 & 325 & I5I & $23^{8}$ & 207,060 \\
\hline $\begin{array}{l}\text { B. macrostachys } \\
\text { B. pratensis }\end{array}$ & I.9 & 5 & $22 \mathrm{I}$ & 357 & $39 \circ$ & 390 & $3^{25}$ & I95 & & & 1878 & 195 & 325325 & 5 & 325 & I95 & & & 1710 & 210 & 293 & 146 & 219 & $19^{2}, 063$ \\
\hline B. inermis & $\mathrm{I} \cdot 2$ & 5 & 143 & 293 & 292 & 292 & 293 & $9^{8}$ & & & $\mathrm{I}_{4} \mathrm{II}$ & 163 & 318305 & $5 \mid 311$ & $3 \circ 5$ & 182 & & & ${ }^{1} 5^{8} 4$ & 218 & 260 & ${ }^{11} 7$ & 188 & ${ }^{\mathrm{I}} 55,35^{8}$ \\
\hline B. velutinus & 2.0 & 5 & 227 & 390 & $39^{\circ}$ & $39^{\mathrm{I}}$ & 390 & 227 & & & 2015 & 280 & 455409 & 9390 & $39^{\circ}$ & 260 & & & 2184 & 236 & $34^{2}$ & I 33 & 237 & 201,190 \\
\hline B. sterilis & $2 \cdot 0$ & 5 & 228 & 377 & $35^{\mathrm{I}}$ & 325 & 364 & 195 & & & 1840 & 260 & 435423 & ${ }_{3} \mid$ & 455 & 253 & & & 2294 & 243 & 293 & IOI & 197 & ${ }^{1} 76,3^{1} 5$ \\
\hline B. maximus & $3 \cdot 0$ & 7 & 195 & $3^{2} 5$ & 520 & 5201 & 520 & $5^{20}$ & 390 & 169 & $3{ }^{1} 59$ & 195 & 410520 & $0520 \mid$ & 520 & 507 & $33^{8}$ & 182 & $3^{1} 9^{2}$ & $4^{10}$ & 325 & 147 & 236 & 205,685 \\
\hline B. madritensis & I.7 & 5 & 182 & $33^{8}$ & 325 & 325 & $35^{\mathrm{I}}$ & I69 & & & 1690 & 195 & 325305 & $5 \mid 325$ & 325 & 195 & & & 1670 & 192 & $21_{4}$ & I 20 & 203 & I 79,655 \\
\hline B. Schraderi & $2 \cdot I$ & 7 & I30 & 292 & 325 & 325 & 325 & 325 & 260 & I30 & 2112 & 130 & $280 \quad 312$ & 2325 & $33^{8}$ & $29^{2}$ & 260 & I 30 & 2067 & 333 & I 88 & 100 & I 44 & 120,808 \\
\hline B. unioloides & $2 \cdot 5$ & 7 & 162 & 293 & $33^{8}$ & $33^{2}$ & 326 & $39^{\circ}$ & 299 & 163 & 2303 & 195 & $35 \mathrm{I} 390$ & 0403 & $39^{\circ}$ & $39^{\circ}$ & 325 & 162 & 2606 & 327 & 260 & I49 & 204 & 178,402 \\
\hline B. racemosus & $\mathrm{I} \cdot 75$ & 5 & I96 & $36_{5}$ & 330 & 330 & 360 & 220 & & & $180 \mathrm{I}$ & 307 & $390 \quad 37 \mathrm{I}$ & $\mathrm{I} \mid 345$ & 384 & 262 & & & 2059 & 249 & 288 & 120 & 204 & ${ }^{179,3} \mathrm{I}^{6}$ \\
\hline B. commutatus & I.I & 3 & 160 & $4^{16}$ & 420 & 190 & & & & & II 86 & 185 & 340 & 0.160 & & & & & 1035 & 134 & 224 & 109 & 166 & $I_{44,420}$ \\
\hline B. interruptus & 1.0 & 3 & 160 & $37 \mathrm{I}$ & 352 & 160 & & & & & 1043 & 204 & 422439 & \begin{tabular}{l|l|}
39 & 198
\end{tabular} & & & & & 1263 & 147 & 268 & 122 & I95 & $172,3 \circ 3$ \\
\hline B. arvensis & I. 2 & 3 & 192 & 360 & 384 & 172 & & & & & 1108 & $19^{8}$ & \begin{tabular}{l|l|l}
$388_{4}$ & 371
\end{tabular} & \begin{tabular}{l|l|}
1 & 192
\end{tabular} & & & & & II 45 & I 34 & 262 & 96 & 179 & ${ }^{1} 55,857$ \\
\hline B. canadensis & $\mathrm{I} \cdot 7$ & 5 & I95 & $3^{25}$ & $3^{25}$ & 325 & 325 & 162 & & & 1657 & 208 & $3643^{312}$ & $\left.{ }^{2}\right|^{306}$ & 312 & 195 & & & I697 & 269 & 273 & 162 & 217 & 182,497 \\
\hline
\end{tabular}

Ann. Bot., Vol. XVI. To face p. 307.] 

transverse sections, not too thin, in alcohol and glycerine to which water or eau-de-javelle are added in various proportions.

The margins of all the species examined are strengthened by sclerenchyma-cells arranged in a long thin band, and a similar feeble band runs down the crest of the keel below the mid-ribs. In very rare cases a much feebler strand runs below the two stronger secondary bundles. In no case does the amount of sclerenchyma approach the dignity of a girder, as it so often does in the broader leaves of mature plants.

The margins of all species examined, with the exception of one which is probably not a true Brome, have short sharp asperities with the points turned upwards, sometimes with some turned downwards. Similar asperities occur also on the mid-rib or stronger ribs of $B$. unioloides, in addition to the hairs proper, but in no other Brome examined has this character been found to occur.

\section{i3. Dimensions of the Leaf.}

Although differences of some value as regards length of leaf are attainable, so long as we confine our attention to seedlings growing under the same conditions, I pass them by as of relatively little importance in the present connexion. In Table XXIII are set forth the measurements of (I) the average breadth of the whole leaf; (2) the number of ribs; (3) the intervals between the ribs as measured on the translucent solid pieces of leaf; (4) the same intervals as measured with a higher power on transverse sections; (5) the average total breadth of the vascular bundles of the ribs, as measured on transverse sections; (6) the depth of the mid-rib from the crest of its ridge above to the crest of the keel below; (7) the depth of the leaf at the middle of the sinus between a pair of ridges, also, like the last, measured on the transverse section; and lastly ( 8 and 9) the calculated sectional area of chlorophyll-tissue in each interval, and its volume for each square millimetre of leaf-surface.

Columns I to 4 explain themselves. It is only necessary to remark that precautions were taken to compare any 
shrinkage in breadth due to the action of the reagents employed in preserving and mounting. The danger is a real one, because the contraction of the motor-cells under certain circumstances may vitiate the measurements by drawing together the whole upper surface of the leaf. I found, however, that with the properly hardened material relaxed in glycerine jelly and measured at once, this danger was reduced to a minimum, and the measurements compare very accurately with those made on fresh specimens. Nevertheless, I took the precaution to institute check measurements (see columns 3 and 4) of the rib-intervals throughout by two different methods, and it will be noticed how closely the results set forth in column I (measurement with a lens direct) usually agree with the totals in columns 3 and 4 . Moreover, it should be noted that exactly the same treatment throughout was accorded to all the species.

In measuring the intervals, in column 3 the micrometer scale ${ }^{1}$ was made to travel from the axis of one rib to that of the next, or (column 4) from the centre of one vascular bundle to that of the next. It will be noticed that the distance from rib to rib is often greater on one side of the mid-rib than on the other. This inequality in the breadth of the two halves of the lamina of grass leaves has often been observed, but, so far as I am aware, no explanation has been given of it. It appears to be due to the fact that the smaller half-lamina was the innermost in the involuted state of the leaf in the bud, and thus had less room for lateral extension, its growth being hindered by the pressure of the surrounding parts - the enveloping outer half-lamina and sheath-between which it is trapped, as it were. The same mechanical pressures help to arrest the longitudinal growth also, and so induce the twist ${ }^{2}$ in the lamina by rendering one edge shorter than the other.

1 I used a Zeiss 'Mess-ocular' with travelling scale, and a mechanical stage.

2 This twisting of adult grass leaves has often been noticed. See an interesting paper by Max Wichura in Scientific Memoirs, Parts III and IV, 1853, p. 262, where, however, the author failed to give any satisfactory explanation of the phenomenon. 
Columns $5^{-7}$ were introduced in order to give the data for obtaining the approximate calculations in columns 8 and 9, viz. calculations of the mean area of chlorophyll-tissue and epidermis divested of the vascular tissue and alone attackable by the Fungus. I tried several methods of more direct measurement of this tissue before deciding that the irregular shape of the leaf defeated all attempts to obtain such. But it appeared so necessary to ascertain, however approximately, whether any relation exists between the volume of attackable tissue per square unit of leaf-area, and the susceptibility or immunity of the species, that I hit upon the following device.

Having subtracted the width of the vascular bundles (column 5) from the total width of the leaf (column 4) as measured on sections, I took the mean depth of the leafsection from columns 6 and 7 , and then treated the whole as a rectangle. The area of this gives us the result shown in column 8 , reduced to a rectangle with its longer side equal to one millimetre. This sectional area multiplied by $\mathrm{I}, 000$ gives us the volume of tissue per I sq. $\mathrm{mm}$. of leaf surface.

It must be admitted that these areas and volumes cannot be exact. The ideal object of attainment would be the volume of the cells and inter-cellular spaces, numbers of chlorophyll-grains and their sizes, and so on, but I found it hopeless to expect any success in carrying out such estimations as were attempted in this connexion.

One point that has to be attended to is to allow for the inter-osculations of vascular bundles by lateral bundles. It is quite a mistake to suppose that the 'veins' of grasses are all parallel; they are netted, and the only device I could think of for allowing for the lateral connexions was to deduct the tissues immediately above and below the much-predominating main ribs. In any case, this is the least attacked of all the non-vascular tissue.

Perhaps all I can claim for this part of the subject is to have suggested a method which can be improved upon in future measurements. If the latter were made on a sufficiently 
large scale I think average results of value could be obtained. and tested.

\section{I4. Stomata.}

I have elsewhere ${ }^{1}$ published the details of my examination of the stomata, showing that there is no discoverable relation between their sizes and numbers, and may refer to that demonstration for information as to the methods of estimation and of checking pursued. It was natural to expect that, since the germ-tubes enter the leaves via the stomata, the sizes and numbers of the latter would be important factors: on the contrary, they seem to be of no importance whatever in connexion with the question here raised.

\section{HaIRS.}

It is conceivable that the degree of hairiness of the leaf may be a factor in hindering the access of the germ-tubes to the stomata. In any case I found that in certain series of experiments where spores were kept in place on the leaves by fluffy masses of cotton-wool, the germ-tubes frequently ran into the interstices and appeared to lose themselves there instead of finding their way to the stomata. Too much stress must not be laid on these observations, however, since such wet pads of cotton-wool may have altered the conditions considerably-e.g., impeding access of oxygen, light, gas interchange and so on-and it is probable that the natural hairs never become thoroughly wetted as were these saturated cotton fibres.

Be this as it may, it seemed worth while to obtain measurements of the length and the relative numbers of the hairs, and the results-obtained simultaneously with those of the stomata and hence by similar methods-are set forth in Table XXIV.

The columns explain themselves. In column I, in addition to the extreme lengths, I have added the commonest averages.

1 Proceedings of the Cambridge Philosophical Society, vol. xi, Part V (1902), pp. $3^{18-323}$. 


\begin{tabular}{|c|c|c|c|}
\hline \multirow{14}{*}{ 离 } & \multirow{2}{*}{ 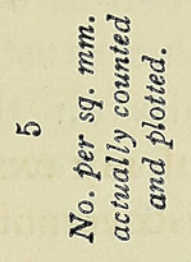 } & $\ddot{Q}$ & 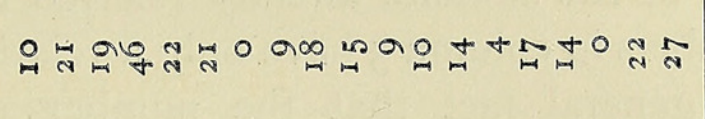 \\
\hline & & $\dot{\nabla}$ & 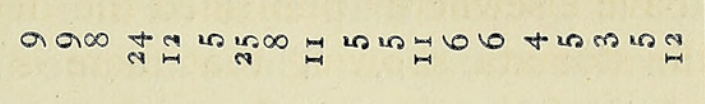 \\
\hline & \multirow{2}{*}{ 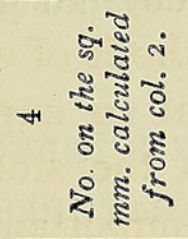 } & $\infty 0^{\circ}$ & O맴에 \\
\hline & & षं & 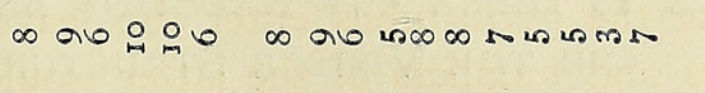 \\
\hline & \multirow{2}{*}{ 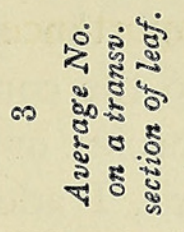 } & $8 \dot{\theta}^{\circ}$ & m \\
\hline & & $\dot{\nabla}$ & 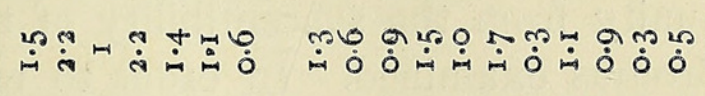 \\
\hline & \multirow{2}{*}{ 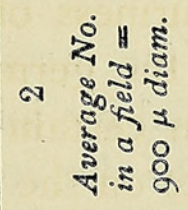 } & $\infty \dot{a}$ & 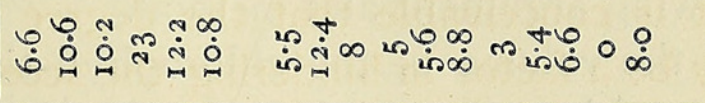 \\
\hline & & $\dot{\nabla}$ & 的 \\
\hline & \multirow{5}{*}{ 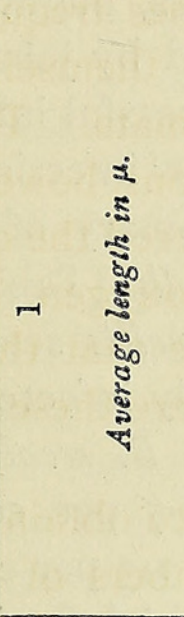 } & ฐัँ & 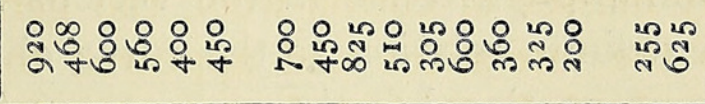 \\
\hline & & & 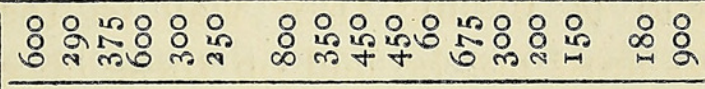 \\
\hline & & $\infty 0^{\circ}$ & 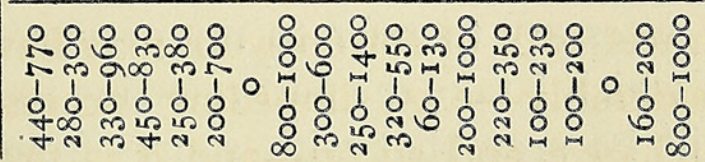 \\
\hline & & \multirow[b]{2}{*}{$\dot{\nabla}$} & 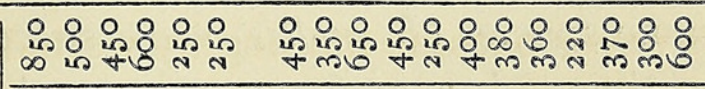 \\
\hline & & & 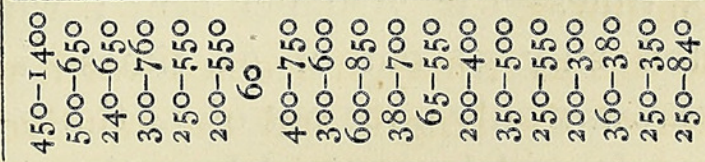 \\
\hline & \multicolumn{2}{|l|}{ 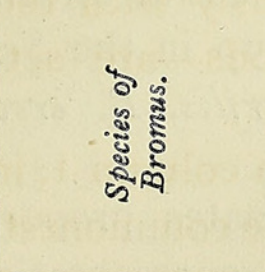 } & 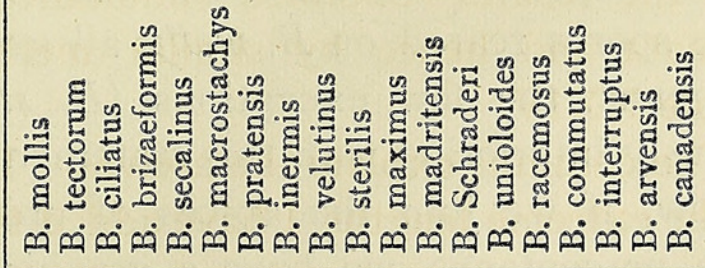 \\
\hline
\end{tabular}


Columns 2 and 4 are useful checks on column 5 , as in the case of the stomata already referred to. Also as before, the numbers in column 3 have only a relative value, as establishing the general fact that the number of hairs on the lower surface is greater than that on the upper, thus reversing the rule for the stomata. There are one or two discrepancies, but I am inclined to regard the results given in column 5 as most reliable.

\section{IS THERE ANY RELATION BETWEEN INFECTION and the Visible Structural Features?}

It now remains to see whether any of the structural peculiarities referred to stand in relation to the comparative immunity from the susceptibility of the species or varieties of Bromus examined. In order to test this, I adopted the following argument and method.

If the volume of the chlorophyll-tissue, for instance, is a factor of importance, then the curve obtained by joining the apices of ordinates of lengths proportional to the volumes of the chlorophyll-tissue in the various species, ought to bear some definite relation to the curve obtained by joining ordinates proportional to the percentage of successful infections.

In order to understand the nature of this 'infection-curve,' it is necessary to refer to my previous summary of results ${ }^{1}$, from which I take the part referring to B. mollis (Table XXV). It will be seen that with spores from $B$. mollis seedlings of the same species $(B$. mollis) were successfully infected 60 out of 85 times-i.e. 70.6 per cent.; whereas $B$. secalinus was infected only $3^{I}$ out of $6 \mathrm{I}$ times-i.e. 50.7 per cent., and B. maximus only once out of 74 times-i.e. $1 \cdot 3$ per cent., and so on. It will be noticed how the successful infections with these spores reared on $B$. mollis all group in the Serrafalcus sub-genus, the few exceptions ( $B$. sterilis, $B$. erectus) not seriously interfering with this statement.

Now, if we join the apices of ordinates proportional to these percentages, we have a graphic representation which

\footnotetext{
${ }_{1}$ Proc. Cambridge Philos. Soc., vol. xi, Part V, pp. 323-328.
} 


\section{TABLE XXV.}

Summary of results of infection in 843 experiments in which spores from $B$. mollis were used as inoculating material.

\begin{tabular}{|c|c|c|c|}
\hline Species infected. & $\begin{array}{l}\text { No. of } \\
\text { plants. }\end{array}$ & $\begin{array}{l}\text { Results } \\
\quad+\text { in. }\end{array}$ & $\begin{array}{l}\text { Per cent. } \\
\text { successful. }\end{array}$ \\
\hline B. erectus & 37 & I & $2 \cdot 7$ \\
\hline B. inermis & $3^{2}$ & 0 & 0 \\
\hline B. ciliaris ( 1 ) & 20 & 0 & $\circ$ \\
\hline B. tectorum & $2 I$ & 0 & ० \\
\hline B. sterilis & 90 & 4 & $4 \cdot 4$ \\
\hline B. madritensis & 77 & 0 & 0 \\
\hline B. maximus & 74 & I & $I \cdot 3$ \\
\hline B. secalinus & $6 \mathrm{I}$ & $3 I$ & 50.7 \\
\hline B. velutinus & 62 & 35 & $56 \cdot 4$ \\
\hline B. arvensis & 76 & 28 & 36.8 \\
\hline B. mollis & 85 & 60 & 70.6 \\
\hline B. racemosus & 56 & I 5 & $26 \cdot 8$ \\
\hline B. commutatus & 45 & 14 & $3 I \cdot I$ \\
\hline B. interruptus & 49 & 19 & 38.8 \\
\hline B. brizaeformis & 18 & 5 & 27 \\
\hline B. macrostachys & I 2 & 4 & 33 \\
\hline B. unioloides & 2 & o & 0 \\
\hline B. Schraderi (2) & 9 & o & 0 \\
\hline B. canadensis & 2 & o & 0 \\
\hline B. giganteus (3) & I & o & o \\
\hline B. pratensis (3) & I4 & $\circ$ & $\circ$ \\
\hline
\end{tabular}

(1) Species needs examining.

(2) Synonym of preceding.

(3) Species requires further examination.

I term the 'infection curve.' And just as this is possible for the case given, so also different curves are obtainable for the infections with spores from $B$. sterilis, $B$. secalinus, \&c. ${ }^{1}$

On drawing these two curves, the result shows there is no resemblance between them: nor is there any resemblance between the infection curve-as it may be termed-and the curves of the sizes or of the number of stomata, of the sizes and numbers of hairs (Tables XXVI and XXYII), of the area of the leaves (Table XXVIII), or in short the curves of any of the structural factors of the leaf.

In similar comparison of the curves of stomata and of infection, it is obvious at a glance that while spores from Bromus mollis infect that species readily, as also they do

1 See Proc. Cambridge Phil. Soc., 1. c., Tables VI and VII. 


\section{I4 Ward.-On Relations between Host and Parasite}

$B$. secalinus and $B$. velutimus with larger stomata, they refuse to infect $B$. inermis with equally large stomata, and only once (out of 74 trials) infected B. maximus with far larger ones.

Or, again, if the small size of the stomata were the explanation of the immunity of $B$. unioloides and $B$. Schraderi, how are we to reconcile this with the only partial immunity of $B$. brizaeformis, where they are much smaller?

Similarly, supposing it were suggested that $B$. macrostachys is as readily infected as $B$. secalimus by spores derived from the latter, because the stomata are approximately identical in size and numbers; we have still to explain how it is that $B$. inermis, with equally large and numerous stomata, is immune, as is also B. maximus with much larger but fewer stomata.

Or again, spores from $B$. sterilis readily infect $B$. madritensis, which has larger but fewer stomata than the former species. How is it that B. maximus is almost immune to these spores, although its stomata are far larger? Is it because they are also fewer? If so, it seems queer that $B$. tectorum should also have proved immune, because its stomata are more numerous than those of $B$. madritensis, and hardly smaller than those of $B$. sterilis. And the results are similar with the other factors. It is useless to reproduce all the curves of the various factors, and it may suffice that I have tried all sorts of combinations and can discover no relations between them and the curves of infection. We are hence driven to conclude that the factors which govern predisposition on the one hand and immunity on the other, are similar to those which govern fertility and sterility of stigmas to pollen, and I have elsewhere ${ }^{1}$ shown that parallels between the behaviour of pollen (which is after all a kind of spore) towards the stigma of the receptive plant in cross-breeding; and of these Uredospores towards their host-plants, multiply as we examine them. The importance of all this is, I think, that it justifies the hopes of those who believe that the con-

1 Proc. Cambridge Phil. Soc., 1. c., pp. 326-328. 



\section{TABLE XXVI.}

Number of Hairs

per $10 \mathrm{~mm}$ of the

leaf surface.(1st.gr.leaf.)

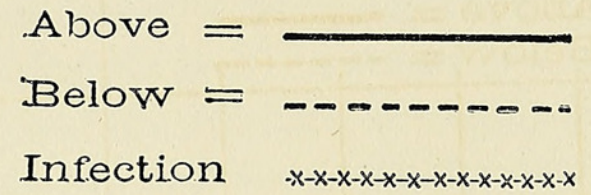

70

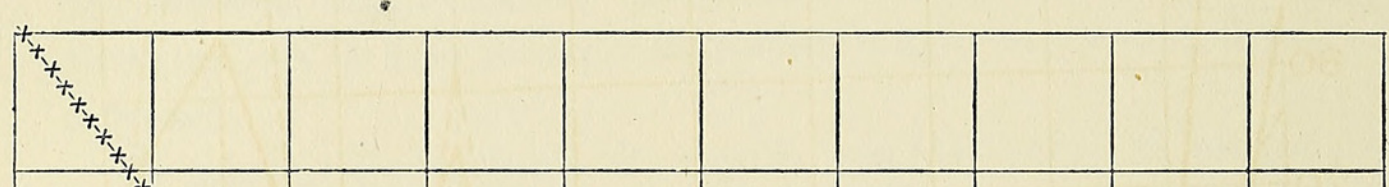

50

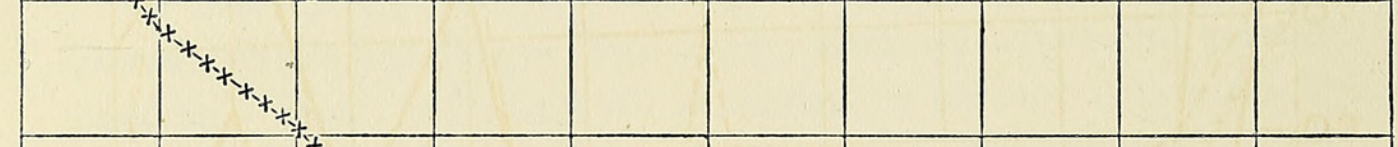

40

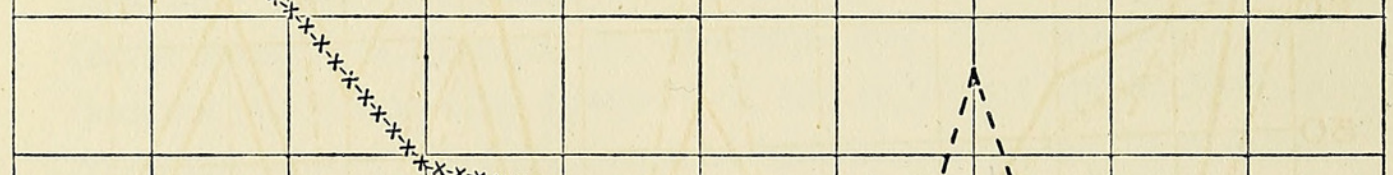

30

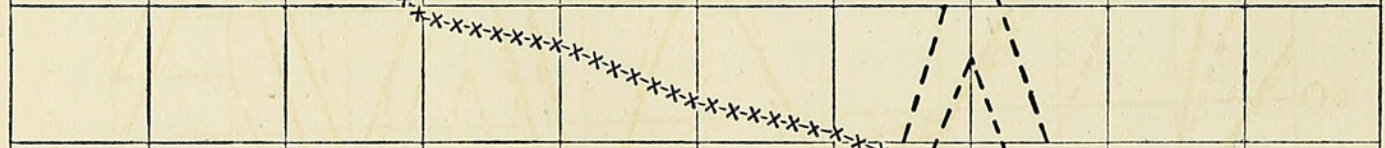

20

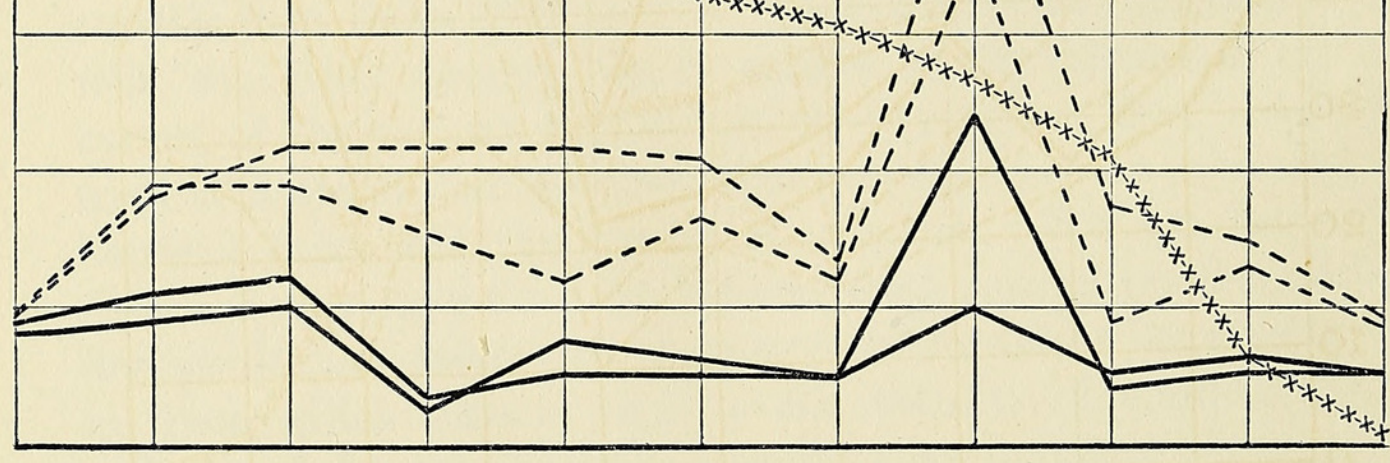

$\mathrm{O}$

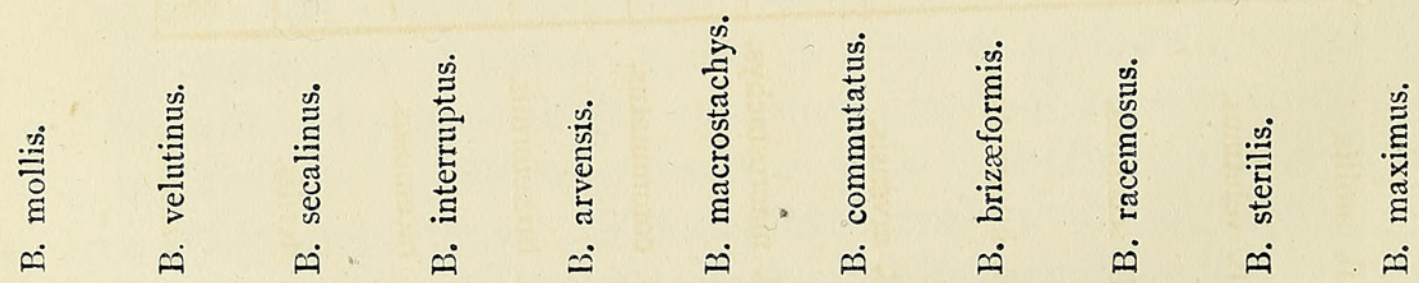


TABLE XXVII.

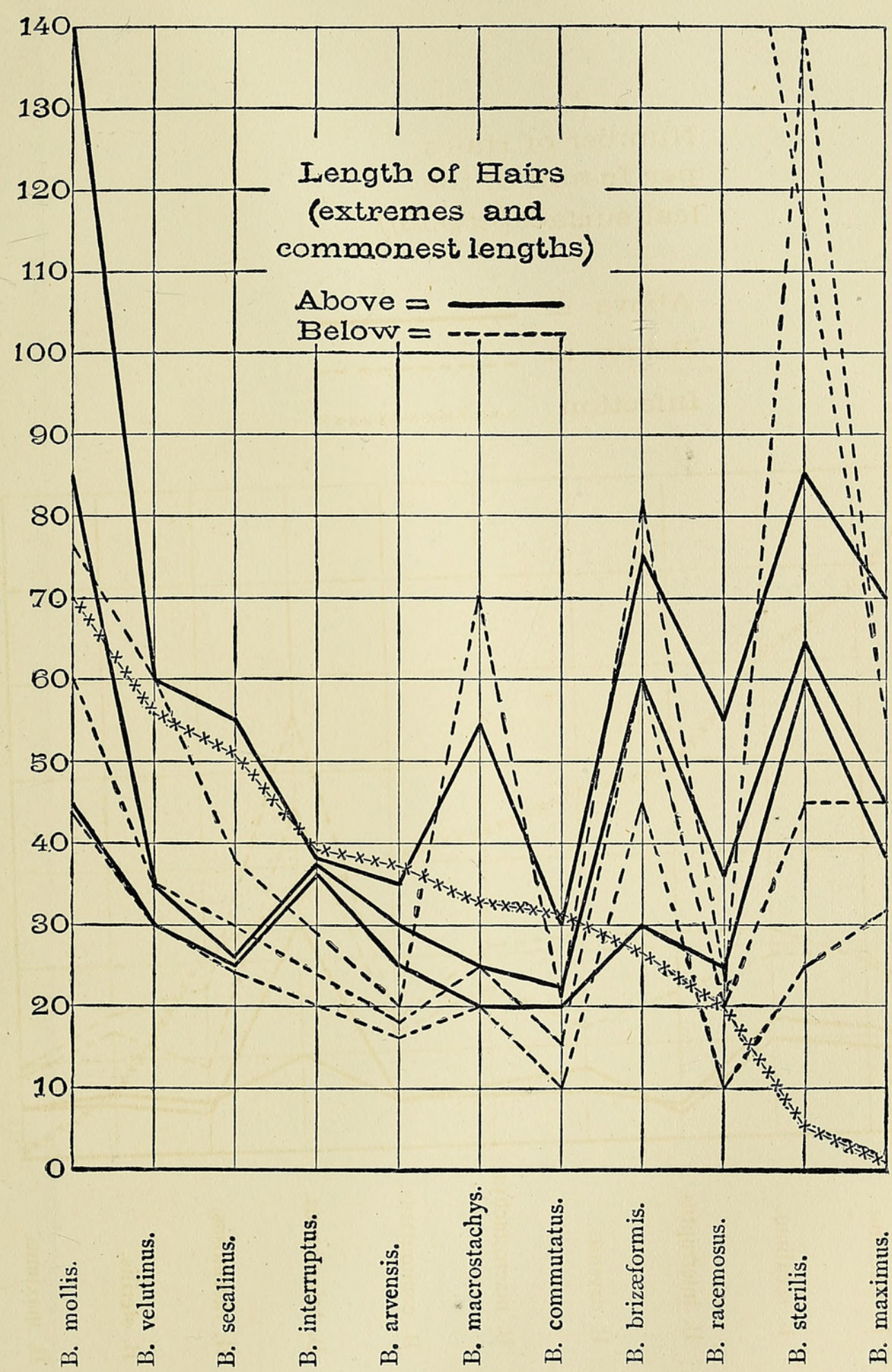





Arnats of Botany

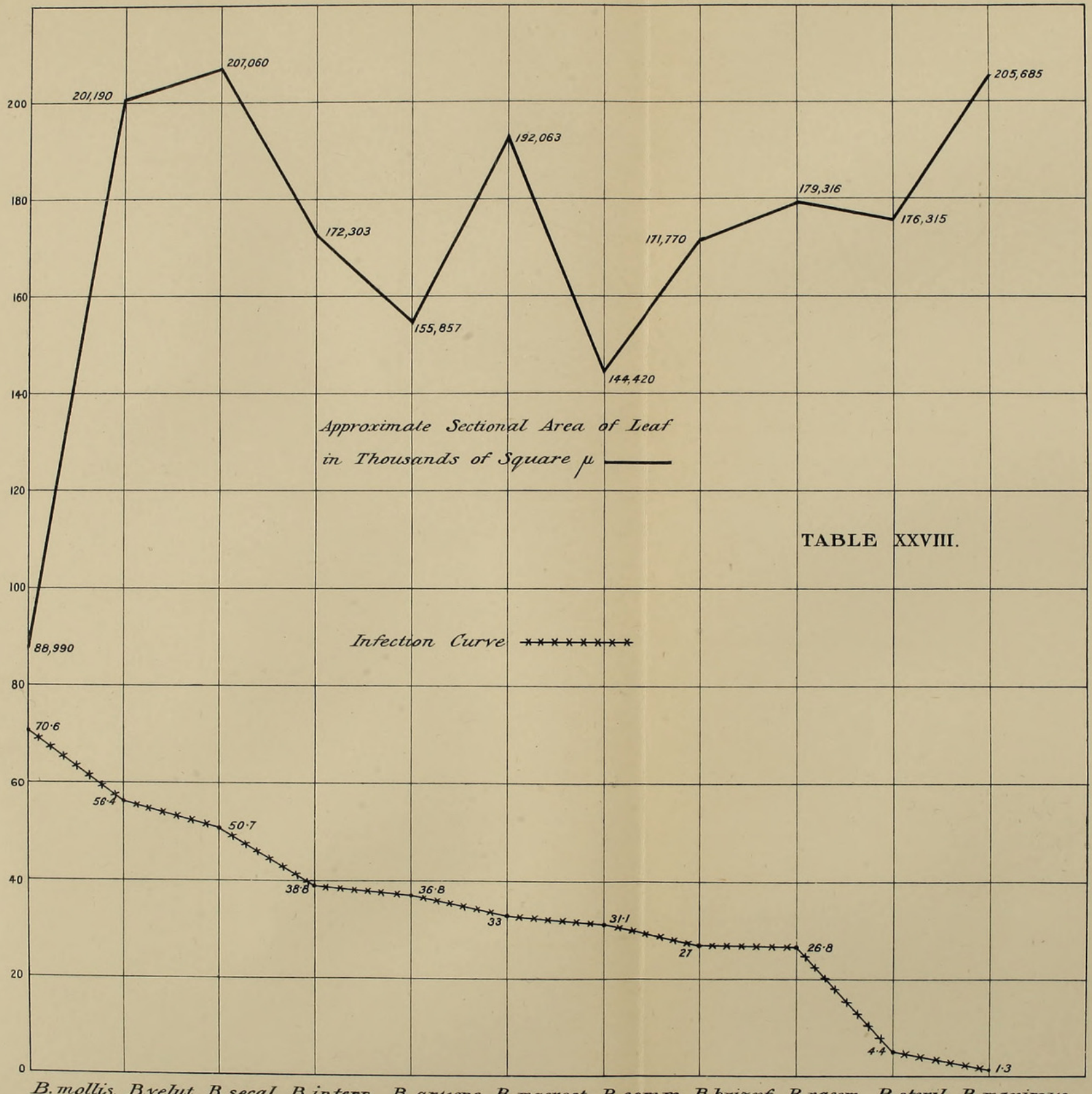

B. mollis. B.velut. B. secal. B. interr. B. arvens, B. macrost. B.comm. B.brixaf. B. racem. B. steru. B.maximus. 



\section{in the Bromes and their Brown Rust. $\quad 315$}

stitution of plants can be so modified by breeding and selection, that disease-resisting varieties should be no more difficult to evolve than varieties which refuse to cross with the pollen of certain other forms. Only, we must not forget that the Fungus is also capable of being bred and selected, and prepotent varieties of spores are just as much realities as prepotent pollen. 


\section{$2 \mathrm{BHL}$ Biodiversity Heritage Library}

Ward, H. Marshall. 1902. "On the relations between host and parasite in the Bromes and their brown rust, Puccinia dispersa (Erikss.)." Annals of botany 16, 233-315. https://doi.org/10.1093/oxfordjournals.aob.a088874.

View This Item Online: https://www.biodiversitylibrary.org/item/233980

DOI: https://doi.org/10.1093/oxfordjournals.aob.a088874

Permalink: https://www.biodiversitylibrary.org/partpdf/318675

\section{Holding Institution}

Smithsonian Libraries

\section{Sponsored by}

Biodiversity Heritage Library

\section{Copyright \& Reuse}

Copyright Status: Not in copyright. The BHL knows of no copyright restrictions on this item.

This document was created from content at the Biodiversity Heritage Library, the world's largest open access digital library for biodiversity literature and archives. Visit BHL at https://www.biodiversitylibrary.org. 